\title{
Simulation of Tidal-Flow, Circulation, and Flushing of the Charlotte Harbor Estuarine System, Florida
}

\section{By Carl R. Goodwin}

U.S. Geological Survey

Water-Resources Investigations Report 93-4153

Prepared in cooperation with the

FLORIDA DEPARTMENT OF ENVIRONMENTAL PROTECTION

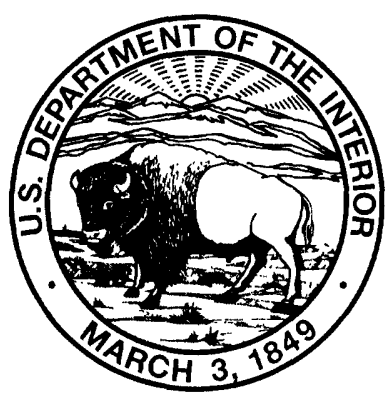




\title{
U.S. DEPARTMENT OF THE INTERIOR BRUCE BABBITT, Secretary
}

\author{
U.S. GEOLOGICAL SURVEY \\ Gordon P. Eaton, Director
}

Any use of trade, product, or firm names in this publication is for descriptive purposes only and does not imply endorsement by the U.S. Geological Survey.

For additional information write to:

District Chief

U.S. Geological Survey

Suite 3015

227 N. Bronough Street

Tallahassee, FL 32301
Copies of this report can be purchased from:

U.S. Geological Survey Branch of Information Services Box 25286

Denver, CO 80225 
Abstract -

Introduction -

Purpose and scope

Previous studies

Acknowledgments -...... 4

Approach -......... 4

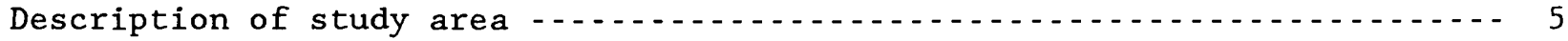

Physical characteristics -

Hydrologic characteristics

Tidal stage -

Discharge at inlets

Tidal velocity

Freshwater inflow -

Salinity -

Hydrodynamic model development for existing conditions -

Governing equations and assumptions _... 14

Numerical methods

Schematization -

Calibration and verification - .

Simulation of tidal-flow and circulation characteristics - .

Lagrangian particle analysis - . -

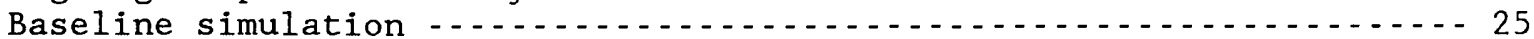

Reduced freshwater inflow simulation - .

Simulation without Sanibel Causeway -

Simulation of flushing characteristics -

Baseline simulation - .

Reduced freshwater inflow simulation $\ldots \ldots \ldots$

Simulation without Sanibel Causeway -

Summary -

References _...

\section{ILLUSTRATIONS}

Figure 1. Map showing Charlotte Harbor estuarine system and subareas - - - 46

2. Map showing generalized bottom configuration of Charlotte Harbor estuarine system and nearshore Gulf of Mexico, and

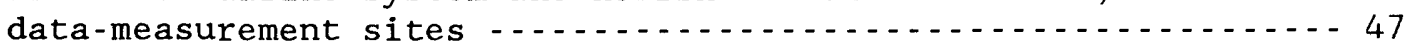

3. Diagram showing cross sections of tidal inlets $\ldots \ldots \ldots$

4. Graph showing typical monthly spring and neap tidal cycle in the Gulf of Mexico and comparative daily tides for the Gulf of Mexico, northern Charlotte Harbor, and southern

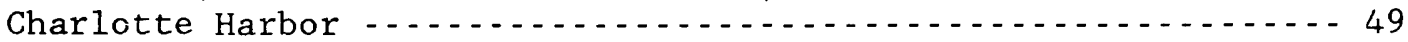

5. Diagram showing typical deployment of tidal velocity current meter - . . .

6. Graph showing streamflow duration curves for the Myakka, Peace, and Caloosahatchee River basins -.................... 52

7. Sketch showing highly-stratified, partially-mixed, and well-mixed vertical distributions of salinity -...-......- 53

8. Graph showing the relation between freshwater inflow from the Peace River and the vertical salinity gradient in northern

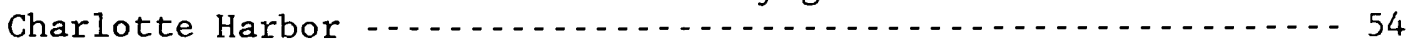

9. Finite-difference scheme for computer simulation model _..... 55 
10. Map showing grid used for the Charlotte Harbor estuarine

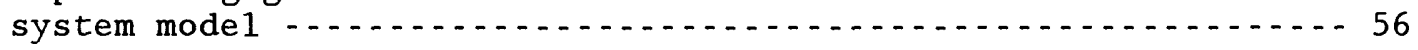

11. Diagram showing data available for model calibration and verification - . . . . . . . 57

12. Graph showing the tidal driving functions used for model calibration and verification at Venice and Fort

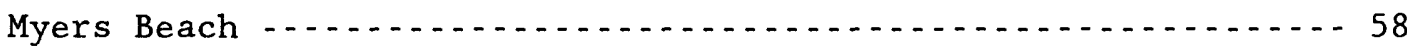

13. Diagram showing barrier cell configuration used for tidal inlets ..........

14-16. Graphs showing simulated and measured:

14. Tidal stages for the calibration and verification

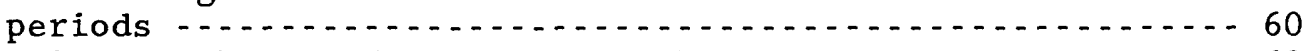

15. Inlet discharges during the calibration period......... 63

16. Velocity data for the verification period ........... 66

17. Graph showing measured tidal-driving function and tidal-driving function generated from harmonic

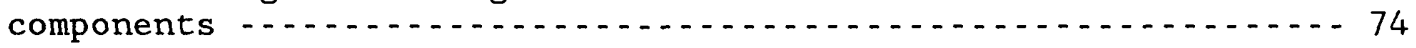

18. Sketch showing example of continuous particle and high-tide particle tracks -.........

19-22. Maps showing selected water-transport vectors during:

19. Floodtide under typical freshwater inflow conditions .... 77

20. Ebbtide under typical freshwater inflow conditions ...... 78

21. High-slack tide under typical freshwater inflow conditions - . . . . 79

22. Low-slack tide under typical freshwater inflow

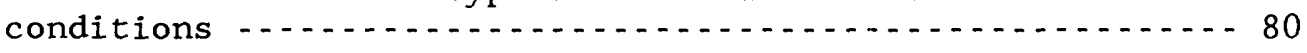

23-26. Maps showing simulated high-tide particle tracks for typical

freshwater inflow and reduced freshwater inflow for:

23. Synoptically injected particles 54, 113, 134, 142,

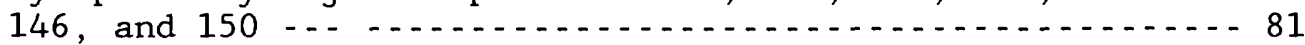

24. Synoptically injected particles $70,74,97,98,129$, 137, and $147 \ldots \ldots 2$

25. Synoptically injected particles 65,91 , and $96 \ldots \ldots \ldots$

26. Sequentially injected particles $172,175,184$,

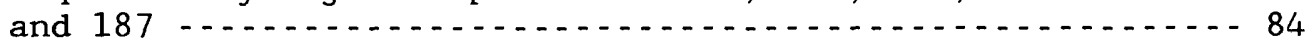

27-30. Maps showing simulated high-tide particle tracks with the Sanibel Causeway and without the Sanibel Causeway for:

27. Synoptically injected particles 54, 113, 134, 142, 146, and $150 \ldots \ldots \ldots 5$

28. Synoptically injected particles $70,74,97,98,129$, 137 , and $147 \ldots \ldots \ldots 6 \ldots$

29. Synoptically injected particles 65,91 , and $96 \ldots \ldots \ldots$

30. Sequentially injected particles 172, 175, 184,

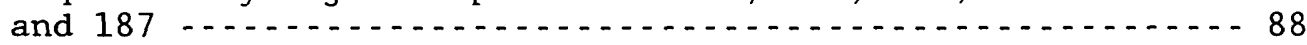

31-34. Graphs showing simulation results from dye injection in:

31. Upper Charlotte Harbor . . . . . .

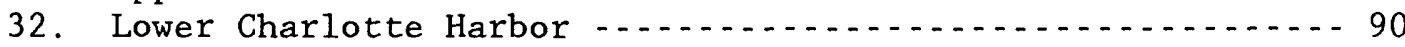

33. Pine Island Sound ...

34. San Carlos Bay -... 


\section{TABLES}

Table 1. Physical Characteristics of the Charlotte Harbor estuarine

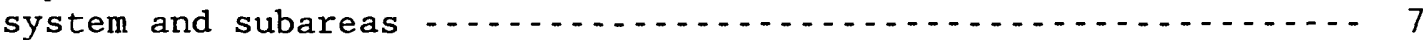

2. Tidal-stage, inlet-discharge, and tidal-velocity measurement

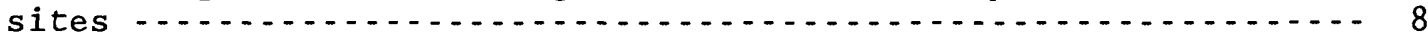

3. Summary of discharge measurements at tidal inlets -........ 10

4. Evaluation of near-bottom point velocities and depth-averaged velocities in Charlotte Harbor, July 17-22, 1986 ........... 11

5. Summary of tidal-velocity measurements in Charlotte Harbor -...-12

6. Standard errors between observed and computed tidal stage and inlet discharges for calibration and verification periods -.... 22 
CONVERSION FACTORS, VERTICAL DATUM, AND ADDITIONAL ABBREVIATIONS

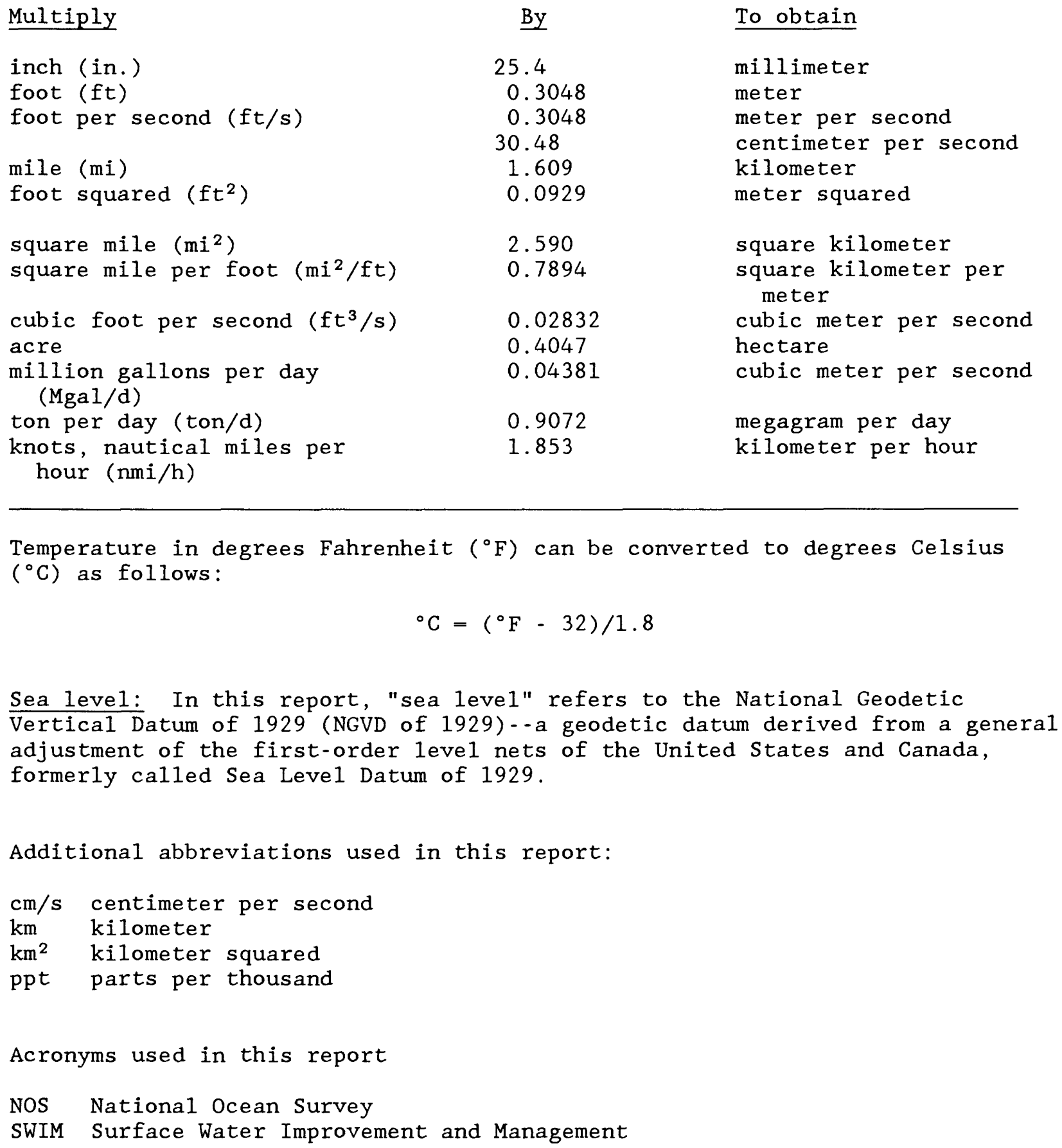




\title{
SIMULATION OF TIDAL-FLOW, CIRCULATION, AND FLUSHING OF THE CHARLOTTE HARBOR ESTUARINE SYSTEM, FLORIDA
}

\author{
By Car1 R. Goodwin
}

\begin{abstract}
A two-dimensional circulation and constituent-transport mode1, SIMSYS2D, was used to simulate tidal-flow, circulation, and flushing characteristics in Charlotte Harbor. The model was calibrated and verified against field observations of stage, discharge, and velocity. Standard errors averaged about 3 percent of the range in stage at the tide stations and between 3 and 10 percent of the range in discharge measured in the inlets for the calibration period.
\end{abstract}

Following calibration and verification, the model was applied to three different conditions. The first condition represented the existing physical configuration and typical freshwater inflow. The second condition represented reduced freshwater inflow, and the third represented an alteration of Sanibel Causeway. All three conditions were evaluated through Lagrangian particle tracks and simulated dye injections.

Residual circulation patterns were similar for typical and reduced freshwater inflow, but reduced freshwater inflow increased the residence time in the upper harbor by a factor of two or more. Removal of Sanibel Causeway did not significantly affect residual flows in upper and lower charlotte Harbor, Matlacha Pass, Gasparilla Sound, or the Gulf of Mexico. Analysis of Lagrangian particle tracks indicated changes in residence times in San Carlos Bay as a result of removing Sanibel Causeway, but the changes were not consistent for all particles. The residence time of 8 particles in San Carlos Bay decreased with removal of the causeway, 1 was unchanged, and the residence time of 3 particles increased.

Simulated flushing characteristics of the estuarine system were affected more by reduced freshwater inflow than by removal of Sanibel Causeway. The time required to flush injected dye from some subareas of the harbor was longer for reduced freshwater inflow than for typical freshwater inflow. After 30 days of simulation of reduced freshwater inflow, 42 percent of the dye injected into the upper harbor remained in the upper harbor, compared to 28 percent for typical freshwater inflow. The upper harbor has a relatively long flushing time because it is not directly connected to the gulf and some of the dye that exits to the lower harbor returns to the upper harbor by way of a landward residual flow in the deep center channel. The upper harbor is also sensitive to reduced freshwater inflow because it is the subarea closest to freshwater inflow from the Peace and Myakka Rivers. Removal of Sanibel Causeway had a slight effect on the flushing of Pine Island Sound and San Carlos Bay, but had no significant effect in upper and lower Charlotte Harbor. 


\section{INTRODUCTION}

Charlotte Harbor, a coastal-plain, estuarine system in west-central Florida (fig. 1), is a vital resource of the State. It is the second largest estuarine system in Florida and one of the most productive in the Nation for commercial and sports fisheries. Its waters and surrounding lands provide food and habitat for about 40 endangered and threatened species (Florida Department of Natural Resources, 1984).

Charlotte Harbor is being subjected to increased environmental stress by rapid population growth and development. By the year 2020, more that 500,000 new residents could live in the area that drains into the harbor (Hammett, 1990). Waterfront housing, construction of roadways and bridges across parts of the harbor, and boat-channel dredging could accompany projected increases in population. With growth and development, there is an increased demand for freshwater and a corresponding increase in urban, agricultural, and industrial wastes. Freshwater might be withdrawn or diverted from the rivers and streams that flow into the estuary at the same time that wastewater discharges are increasing.

To evaluate the potential response of the estuarine system to growthinduced changes, it is necessary to define the hydrodynamic characteristics of the estuary and its interaction with the inflowing river systems and the Gulf of Mexico. Any change in the physical configuration of the estuarine system, such as dredging or causeway construction, or any alteration in river inflows, might affect circulation patterns in the harbor and, consequently, cause longterm changes in the distribution of all waterborne material.

In 1987, Charlotte Harbor was ranked sixth in priority among water bodies designated for restoration or preservation as part of the Surface Water Improvement and Management (SWIM) Act of Florida (Southwest Florida Water Management District, 1988). The importance of studying the Charlotte Harbor estuarine system was recognized several years prior to the SWIM Act when the Governor of Florida established a committee of representatives from local, regional, State, and Federal agencies to evaluate the course of action that Florida might take to protect the estuarine system. At the request of this committee, the U.S. Geological Survey developed a plan of study and began a 7-year, multidisciplinary assessment of Charlotte Harbor and its inflow area in 1982, in cooperation with the Florida Department of Environmental Regulation.

\section{Purpose and Scope}

This report presents results of the simulation of tidal-flow, circulation, and flushing characteristics of the Charlotte Harbor estuarine system, using a two-dimensional, estuarine circulation, and constituent transport model (SIMSYS2D) described by Leendertse and Gritton (1971). The report addresses three objectives of the Charlotte Harbor environmental assessment:

1. Collect and analyze sufficient field data to describe the general tidal and other hydraulic features of the estuarine system.

2. Develop an appropriate hydrodynamic model to simulate measured tidal hydraulic features of the Charlotte Harbor estuarine system as it existed in 1986 and apply the model to help describe tidal-flow, circulation, and flushing characteristics. 
3. Use the model to evaluate changes in tidal-flow, circulation, and flushing characteristics that might result if freshwater inflow were reduced or if the Sanibel Causeway were altered.

Data that were collected, analyzed, or published as part of the overall environmental assessment of Charlotte Harbor were used for this study.

Additional field activities to support this part of the investigation included automatic recording of tidal stage at eight sites for a period of several months during the summer of 1986 and automatic recording of tidal velocity at six estuarine and three offshore sites for a period of about 4 weeks from early July to early August 1986. Tidal-cycle discharge was measured at seven major passes and supplementary velocity profiles were recorded at numerous sites in the study area during July 17-22, 1986.

Data were analyzed to characterize the tidal-stage range and phase relations between the various sites, and harmonic analysis techniques were used to provide suitable long-term boundary input for the hydrodynamic model. Tidal-velocity data were analyzed using sequential vector presentations, and summation of the vectors over many days revealed residual tidal motion. Velocity profiles collected in the major passes during one tidal cycle were combined with cross-sectional information to compute inlet discharge.

Simulation results are portrayed primarily in map and graphical form to show computed flow, circulation, and constituent-concentration patterns. The differences between patterns, and the variability of selected parameters in time or space are compared for typical and reduced freshwater inflow. The differences between tidal-flow, circulation, and flushing characteristics that might result if the physical configuration of the Sanibel Causeway is altered are also illustrated.

\section{Previous Studies}

Literature that describes the tidal-flow, circulation, and flushing characteristics of the Charlotte Harbor estuarine system is limited. Available data are restricted to short periods of time and a limited number of sites associated with specific investigative studies. One exception is the tidal stage and velocity predictions published annually by the U.S. Department of Commerce (1985a, b). Another exception is data collected as part of the regular water-quality monitoring of upper Charlotte Harbor and the lower Peace River by the Enviṛonmental Quality Laboratory of Port Charlotte, Florida.

A variety of published reports have resulted from the U.S. Geological Survey's environmental assessment of Charlotte Harbor. Previous reports have provided a literature assessment of Charlotte Harbor (Stoker and Karavitis, 1983); a summary of water-quality data (Stoker, 1986); a description of the characteristics of the inflow area and a discussion of what changes may occur as a result of projected growth and development (Hammett, 1990); and a description of the salinity characteristics of Charlotte Harbor and two of the major tributaries to the harbor (Stoker, 1992; Stoker and others, 1989; Hammett, 1992). McPherson and Miller (1990) discuss the nutrient distribution variability in Charlotte Harbor and a one-dimensional flushing analysis of the upper harbor is provided by Miller and McPherson (1991). 
Other articles discuss light attenuation in estuarine waters (McPherson and Miller, 1987), infaunal macroinvertebrates (Estevez, 1986), water-quality trends (Fraser, 1986), concentration and transport of phosphorus and radium226 in the Peace River and Charlotte Harbor (Miller and McPherson, 1987), phytoplankton productivity (McPherson and Montgomery, 1989). The information and techniques developed for this study has broad application, not only to Charlotte Harbor, but to other estuarine systems.

Previous computer simulation studies of the area include a threedimensional demonstration model of a $6.84-\mathrm{mi}$ by $6.84-\mathrm{mi}$ area of upper Charlotte Harbor (Sheng and others, 1985). This study was primarily an effort to develop software that could show the general capabilities of the model to compute realistic velocity and salinity values in the three-dimensional domain. Data were not available to calibrate this model. Scarlatos (1988) describes a one-dimensional hydrodynamic and constituent transport model that is being developed to simulate tidal and salinity conditions in the tidal Caloosahatchee River.

As part of an investigation to determine the feasibility of modifying the Sanibel Causeway, a two-dimensional hydrodynamic model was applied to the Charlotte Harbor estuarine system by Hydrosystems Associates, Inc. (1989). This investigation concluded that flows in Charlotte Harbor are dominated by Boca Grande Pass and that construction of the present Sanibel Causeway affected velocities in Redfish and Captiva Passes by less than 1 percent. This study also concluded that causeway construction resulted in a change in velocity over 1,620 acres immediately adjacent to the bridges and islands. No information was presented regarding any possible effects on long-term residual currents or flushing rates of the estuarine system as a whole, or in the region near the Sanibel Causeway.

Because of the similarities between the Charlotte Harbor estuarine system and Tampa Bay, which is about $100 \mathrm{mi}$ north on the west coast of Florida, many of the modeling and interpretative techniques described by Goodwin (1987; 1991a) for Tampa Bay and its subembayment, Hillsborough Bay, also were used in this investigation. Goodwin quantified tidal-flow and circulation differences in Tampa Bay and in Hillsborough Bay for changes caused by construction of channels, islands, and submerged disposal areas. For Hillsborough Bay, estimates of changes in retention times due to construction also were made.

\section{$\underline{\text { Acknowledgments }}$}

Personnel from the Fort Myers Beach Coast Guard station and from Flotillas 92, 98, 903, 906, and 910 of the Coast Guard Auxilliary in Northport, Punta Gorda, Naples, Wiggins Pass, and Fort Myers, respectively, provided information, assistance, transport for personnel, and platforms for instrumentation used in velocity surveys during July 1986.

\section{APPROACH}

A four-step approach was used to meet the objectives of this part of the Charlotte Harbor study. The steps included (1) development of a preliminary hydrodynamic model, (2) collection and analysis of field data, (3) calibration and verification of the model, (4) and model application. The primary purpose of the preliminary model was to provide a rational basis on which to design data-collection efforts that would produce useful information. This information could characterize the major features of the study area and be 
used to calibrate and verify the model. The preliminary model was constructed early in the study by using existing data. Necessary depths and crosssectional areas were taken from navigation charts of the area. Tidal stages at the model boundary in the Gulf of Mexico were estimated with sinusoidal functions that had amplitudes and frequencies consistent with those predicted by the National Ocean Service (U.S. Department of Commerce, 1985b).

Freshwater inflows from the three major tributaries to the harbor were taken from streamflow records published annually by the U.S. Geological Survey (1986). Bottom friction was estimated using values from Goodwin (1987).

On the basis of circulation features and tidal characteristics revealed by the preliminary model, tidal-stage sites, recording current-meter sites, and tidal-discharge and velocity-profile sites were selected for this study. Sites that are selected using these criteria provide the opportunity to place recording current meters in optimal locations in an attempt to collect sufficient data to confirm or deny the existance of at least some tideinduced, long-term, residual circulation patterns predicted by the preliminary model.

Following data collection, the preliminary model was upgraded using measured tides, measured cross-sectional areas at the tidal inlets, and measured freshwater inflow. Data collected for spring-tide conditions during July 17-22, 1986, were compared with model-simulated conditions and provided the basis for making adjustments to model parameters. Model parameters were adjusted until an acceptable calibration was achieved. Data collected for neap-tide conditions during July 9-16, 1986, were then used to verify the model performance prior to making application runs.

Because flushing of some parts of the Charlotte Harbor estuarine system was expected to take several months, model application runs were extended as long as possible within budgetary constraints. Harmonic functions were developed from measured time series to approximate the mixed tides that occur in the Gulf of Mexico. These harmonic functions provided realistic tidal driving functions for several spring- and neap-tide cycles for 65-day application runs.

The model was applied to simulate hydrodynamic and constituent transport processes for the existing conditions in the estuarine system, for conditions under which freshwater inflow is substantially reduced, and for conditions under which there are alterations to Sanibel Causeway. Results from the three application runs were then analyzed to determine the differences in tidalflow, circulation, and flushing characteristics of the estuarine system for the different conditions simulated.

\section{DESCRIPTION OF STUDY AREA}

The Charlotte Harbor estuarine system (fig. 1) is a series of shallow, interconnected waterbodies on the west-central coast of peninsular Florida and consists of Charlotte Harbor proper, Pine Island Sound, Matlacha Pass, San Carlos Bay, and the tidal reaches of the Myakka, Peace, and Caloosahatchee Rivers. This report also includes Gasparilla Sound as part of the northwest section of the estuarine system, although previous reports that were part of the environmental assessment excluded the sound. The estuarine system occupies parts of Charlotte and Lee Counties and covers an area of about 290 $\mathrm{mi}^{2}$. Gasparilla, Cayo Costa, North Captiva, Captiva, and Sanibel barrier islands separate the estuarine system from the Gulf of Mexico, but several 
tidal inlets provide a hydraulic connection between the gulf and the harbor. The inlets are Gasparilla Pass, Boca Grande Pass, Captiva Pass, Redfish Pass, Blind Pass, and the mouth of San Carlos Bay.

The Charlotte Harbor inflow area consists of the Myakka, Peace, and Caloosahatchee River basins and the coastal area and barrier islands that drain directly into the harbor, an area greater than 4,500 $\mathrm{mi}^{2}$. Total freshwater inflow from the three rivers, runoff from the coastal area, and rain falling directly on the surface of the harbor amounts to between 5,700 and $6,100 \mathrm{ft}^{3} / \mathrm{s}$ (Hammett, 1990). The rivers tributary to Charlotte Harbor transport more than 2,000 ton/d of dissolved solids, about 17 ton/d of nitrogen, and about 6 ton/d of phosphorus (Hammett, 1990). Tidal-flow, circulation, and flushing characteristics determine the speed and distribution of this waterborne material as it moves through the estuarine system.

The climate of the study area is subtropical and humid with an average temperature of $72^{\circ} \mathrm{F}$. Annual rainfall averages about 52 in., with more than half occurring from June through September during localized thundershowers and squalls. Seasonal variations in freshwater runoff cause variations in the concentration and distribution of salinity (Stoker, 1992) and other constituents in the estuary (Stoker, 1986). Tide and wind tend to inhibit density stratifications under most conditions, and the estuary is predominantly well-mixed vertically. Vertical stratification was observed only during periods of high freshwater inflow (Stoker, 1992). Tropical cyclones produce the most severe weather conditions in the study area. Hammett (1990) provides a discussion of the frequency of tropical storms and hurricanes in the study area and provides a list of hurricanes that passed within $50 \mathrm{mi}$ of Charlotte Harbor during the period 1871-1984.

\section{Physical Characteristics}

The generalized bottom configuration of the Charlotte Harbor estuarine system and nearshore region of the Gulf of Mexico is derived from National Ocean Service bathymetric surveys (fig. 2). Offshore features include ebbtide deltas formed at Boca Grande Pass, Captiva Pass, and the mouth of San Carlos Bay. Depths greater then $30 \mathrm{ft}$ occur only in Boca Grande Pass and at distances of 1 to $5 \mathrm{mi}$ offshore from the barrier islands.

The deepest parts of the estuarine system are two extensive areas in Charlotte Harbor that have depths exceeding $12 \mathrm{ft}$. These two areas are separated by a small, natural sill that has depths of 9 to $12 \mathrm{ft}$. The sill was selected as the boundary between the upper and lower subareas of Charlotte Harbor, as shown in figure 1. Much of the remaining part of the estuarine system is very shallow, with extensive tidal flats that have depths of less than $3 \mathrm{ft}$, particularly in eastern Gasparilla Sound and northeastern Pine Island Sound. Natural channels in the southern part of the estuarine system range in depth from 6 to $12 \mathrm{ft}$.

The northern part of the Charlotte Harbor estuarine system includes the lower reaches of the tidal Myakka and Peace Rivers, upper and lower Charlotte Harbor, and Gasparilla Sound. The southern part of the system includes Pine Island Sound, Matlacha Pass, and San Carlos Bay. The northern part of the system is about 43 percent larger in surface area than the southern part and has about 2.3 times the water volume (table 1 ). At mean sea level, the northern part averages $9.3 \mathrm{ft}$ in depth and the southern part averages $5.7 \mathrm{ft}$. The tidal prism, defined as the volume of water that enters or leaves the 
Table 1. Physical characteristics of the Charlotte Harbor estuarine system and subareas

[mi ${ }^{2}$, square mile; ft, feet; $\mathrm{mi}^{2}-\mathrm{ft}$, square mile foot]

\begin{tabular}{|c|c|c|c|c|}
\hline $\begin{array}{l}\text { Estuarine system } \\
\text { and subareas } \\
\text { (fig. 1) }\end{array}$ & $\begin{array}{l}\text { Surface } \\
\text { arez } \\
\left(\mathrm{mi}^{2}\right)\end{array}$ & $\begin{array}{l}\text { Average } \\
\text { depth } \\
\text { (ft) }\end{array}$ & $\begin{array}{l}\text { Water } \\
\text { volume } \\
\left.\text { (mi }{ }^{\mathrm{ft}}\right)\end{array}$ & $\begin{array}{l}\text { Tidal } \\
\operatorname{prisq}_{(\mathrm{mi}} \\
\text { ft) }\end{array}$ \\
\hline $\begin{array}{l}\text { Northern subareas } \\
\text { Upper Charlotte Harbor } \\
\text { (including lower reaches } \\
\text { of Myakka and Peace Rivers) } \\
\text { Lower Charlotte Harbor } \\
\text { Gasparilla Sound }\end{array}$ & $\begin{array}{l}64.7 \\
84.5 \\
20.3\end{array}$ & $\begin{array}{r}9.7 \\
10.3 \\
4.0\end{array}$ & $\begin{array}{r}630 \\
871 \\
82\end{array}$ & $\begin{array}{r}122 \\
144 \\
32\end{array}$ \\
\hline $\begin{array}{l}\text { Southern subareas } \\
\text { Pine Island Sound } \\
\text { Matlacha Pass } \\
\text { San Carlos Bay }\end{array}$ & $\begin{array}{r}118.8 \\
69.4 \\
15.6 \\
33.8\end{array}$ & $\begin{array}{l}5.7 \\
5.3 \\
3.8 \\
7.4\end{array}$ & $\begin{array}{r}676 \\
366 \\
60 \\
250\end{array}$ & $\begin{array}{r}255 \\
142 \\
29 \\
84\end{array}$ \\
\hline $\begin{array}{l}\text { Charlotte Harbor estuarine } \\
\text { system }\end{array}$ & 288.3 & 7.8 & 2,259 & 553 \\
\hline
\end{tabular}

estuary between high slack water and low slack water (Goodwin, 1987, p. 8), is a greater percentage of the total volume of water in the southern part than the northern part (table 1). Therefore, the physical characteristics of the southern part of the system indicate the potential for faster rates of constituent flushing.

The hydraulic characteristics of the Charlotte Harbor estuarine system are greatly influenced by the volume of water flowing through the tidal inlets. The cross-sectional areas of these inlets range from $1,400 \mathrm{ft}^{2}$ to nearly $110,000 \mathrm{ft}^{2}$ (fig. 3). Top widths range from $140 \mathrm{ft}$ to $9,900 \mathrm{ft}$, and maximum depths range from 14 to $55 \mathrm{ft}$. The widest inlet is at the mouth of San Carlos Bay and the deepest is at Boca Grande Pass, but the cross-sectional area of these two inlets is nearly the same. Blind Pass is the smallest inlet and has only about 1 percent of the area of Boca Grande Pass.

Several navigation channels have been dredged within the estuarine system. The largest of these is the Intracoastal Waterway that runs on a southerly course through Gasparilla Sound and Pine Island Sound, then easterly through San Carlos Bay and into the Caloosahatchee River. The waterway has a design depth of $10 \mathrm{ft}$ and widths of 200 to $300 \mathrm{ft}$ (U.S. Department of Commerce, 1981). Many other small, privately-constructed channels are maintained for access to marinas and other establishments.

\section{Hydrologic Characteristics}

The hydrodynamic behavior of the Charlotte Harbor estuarine system is affected not only by physical characteristics, but also by hydrologic characteristics such as tidal-stage oscillations, discharge through tidal inlets, tidal velocity, and freshwater inflow. Existing data were analyzed and new measurements were made to better define these characteristics. The sites or sections where tidal stage, inlet discharge, and tidal velocity were measured are shown in figure 2 and listed in table 2. 
Table 2. Tidal-stage, inlet-discharge, and tidal-velocity measurement sites

\begin{tabular}{|c|c|c|c|}
\hline \multirow{2}{*}{$\begin{array}{l}\text { Site } \\
\text { number }\end{array}$} & \multirow[b]{2}{*}{ Site name and gaging station number } & \multicolumn{2}{|c|}{ Location } \\
\hline & & Latitude & Longitude \\
\hline \multicolumn{4}{|c|}{ Tidal stage } \\
\hline & $\begin{array}{l}\text { Myakka River at El Jobean } \\
(02299496)\end{array}$ & $26^{\circ} 57^{\prime} 40^{\prime \prime}$ & $082^{\circ} 12^{\prime} 50^{\prime \prime}$ \\
\hline & $\begin{array}{l}\text { Peace River at Punta Gorda } \\
(02298300)\end{array}$ & $26^{\circ} 56^{\prime} 37^{\prime \prime}$ & $082^{\circ} 03^{\prime} 31^{\prime \prime}$ \\
\hline 3 & $\begin{array}{l}\text { Charlotte Harbor at Bokeelia } \\
(02293340)\end{array}$ & $26^{\circ} 42^{\prime} 25^{\prime \prime}$ & $082^{\circ} 09^{\prime} 50^{\prime \prime}$ \\
\hline 4 & $\begin{array}{l}\text { Gulf of Mexico at Venice } \\
(02299689)\end{array}$ & $27^{\circ} 04^{\prime} 20^{\prime \prime}$ & $082^{\circ} 27^{\prime} 07^{\prime \prime}$ \\
\hline & $\begin{array}{l}\text { Gulf of Mexico at Cayo Costa } \\
\text { near Boca Grande (02293330) }\end{array}$ & $26^{\circ} 41^{\prime} 11^{\prime \prime}$ & $082^{\circ} 15^{\prime} 29^{\prime \prime}$ \\
\hline 6 & $\begin{array}{l}\text { Pine Island Sound near Captiva } \\
\text { (02293310) }\end{array}$ & $26^{\circ} 33^{\prime} 00^{\prime \prime}$ & $082^{\circ} 11^{\prime} 50^{\prime \prime}$ \\
\hline 7 & $\begin{array}{l}\text { San Carlos Bay at St. James City } \\
(02293288)\end{array}$ & $26^{\circ} 25^{\prime} 52^{\prime \prime}$ & $082^{\circ} 05^{\prime} 00^{\prime \prime}$ \\
\hline 8 & $\begin{array}{l}\text { Gulf of Mexico at Fort Myers } \\
\text { Beach }(02291780)\end{array}$ & $26^{\circ} 27^{\prime} 08^{\prime \prime}$ & $081^{\circ} 57^{\prime} 26^{\prime \prime}$ \\
\hline
\end{tabular}

Inlet discharge

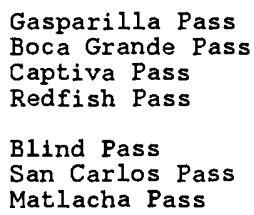

$\begin{array}{ll}26^{\circ} 49^{\prime} & 082^{\circ} 17^{\prime}, \\ 26^{\circ} 43^{\prime} & 082^{\circ} 16^{\prime}, \\ 26^{\circ} 37^{\prime} & 082^{\circ} 14^{\prime}, \\ 26^{\circ} 33^{\prime} & 082^{\circ} 12^{\prime} \\ & \\ 26^{\circ} 29^{\prime} & 082^{\circ} 11^{\prime}, \\ 26^{\circ} 28^{\prime} & 082^{\circ} 00^{\prime}, \\ 26^{\circ} 38^{\prime} & 082^{\circ} 03^{\prime}\end{array}$

Tidal velocity

$\begin{array}{ll}\text { SI-1 } & \text { Upper Charlotte Harbor north } \\ \text { SI-2 } & \text { Upper Charlotte Harbor west } \\ \text { SI-3 } & \text { Upper Charlotte Harbor south } \\ \text { SI-4 } & \text { Gulf of Mexico off Gasparilla } \\ \text { SI-6 } & \text { Pine Island Sound north } \\ \text { SI-7 } & \text { Pine Island Sound middle } \\ \text { SI-8 } & \text { Pine Is land Sound south } \\ \text { SI-9 } & \text { Gulf of Mexico off Redfish } \\ \text { SI-10 } & \text { Gulf of Mexico off Sanibel }\end{array}$

$26^{\circ} 53^{\prime} 54^{\prime \prime} 082^{\circ} 07^{\prime} 18^{\prime \prime}$ $26^{\circ} 47^{\prime} 15^{\prime \prime} 082^{\circ} 07^{\prime} 54^{\prime \prime}$ $26^{\circ} 45^{\prime} 33^{\prime \prime} 082^{\circ} 05^{\prime} 27^{\prime \prime}$ $26^{\circ} 47^{\prime} 26^{\prime \prime} 082^{\circ} 18^{\prime} 10^{\prime \prime}$

$26^{\circ} 39^{\prime} 20^{\prime \prime} 082^{\circ} 11^{\prime} 56^{\prime \prime}$ $26^{\circ} 34^{\prime} 03^{\prime \prime} 082^{\circ} 10^{\prime} 43^{\prime \prime}$ $26^{\circ} 28^{\prime} 45^{\prime \prime} 082^{\circ} 06^{\prime} 39^{\prime \prime}$ $26^{\circ} 34^{\prime} 16^{\prime \prime} 082^{\circ} 14^{\prime} 46^{\prime \prime}$ $26^{\circ} 23^{\prime} 19^{\prime \prime} 082^{\circ} 05^{\prime} 08^{\prime \prime}$

${ }^{1}$ Sites shown on figure 2, except for site 4 - Gulf of Mexico at Venice

\section{Tidal Stage}

Continuous gage-height data were collected at eight sites to define the tidal-stage characteristics of the estuarine system. Water levels along the shore of the Gulf of Mexico were measured at Venice, Cayo Costa, and Fort Myers Beach. In the northern part of Charlotte Harbor, water levels were recorded at E1 Jobean, Punta Gorda, and Bokeelia. Sites near Captiva and St. James City were used to monitor water levels in the southern part of the harbor. The period of record for the sites was variable, but water levels were recorded on a 15 -minute interval during site operation.

Tides along the gulf coast of west-central Florida in the vicinity of Charlotte Harbor are of the mixed type and have both diurnal and semidiurnal characteristics (Goodwin and Michaelis, 1976; U.S. Department of Commerce, 1985b, p. 266). Generally, the mixed type tide has two unequal highs and two unequal lows during each tidal day, with substantial differences in stage between the two highs and between the two lows. The range during a tidal day in July 1986 at Venice varied from $1 \mathrm{ft}$ to more than $3 \mathrm{ft}$ (fig. 4A). Spring 
tides, which have the largest range in stage, often approach and sometimes have only a diurnal fluctuation. Conversely, neap tides, which have the smallest range in stage, approach semidiurnal conditions with two nearly equal high and low water levels per tidal day. The spring and neap cycle occurs in conjunction with the phases of the moon; spring tides occur with new and full moons, and neap tides occur with quarter moons.

The boundary between the Charlotte Harbor estuarine system and the Gulf of Mexico extends about $40 \mathrm{mi}$ from Gasparilla Pass on the north to San Carlos Pass on the south. One of the most apparent features is the larger tidal range at Fort Myers Beach than at either Cayo Costa or Venice (fig. 4B). The reason for the larger tidal range on the southern border of the study area is probably related to the abrupt change in direction of the shoreline at the southern end of Sanibel Island. Another feature is the similarity of the tidal curves at Venice and Cayo Costa. The phasing of the gulf tides is nearly synchronous along the boundary of the estuarine system, although the higher of the high tides tends to lag almost an hour at the southern end. The tide at the southern end also has a stronger semidiurnal component, which is indicated by the more pronounced "step" or "hold-up" tides.

The tidal characteristics in the northern and southern parts of the Charlotte Harbor estuarine system are different (figs. 4C and 4D). Energy dissipation through Boca Grande Pass causes a reduction in tidal range of about 15 percent and a phase lag of about 1 hour at high tide and 2 hours at low tide between Cayo Costa and Bokeelia (fig. 4C). The reduction in tidal range occurs primarily at low tide. The phase lag increases as the tide progresses to Punta Gorda in upper Charlotte Harbor. The total lag between Cayo Costa and Punta Gorda is about 3 hours at high tide and 4 hours at low tide (fig. 4C).

In the southern part of the estuarine system, tidal effects from the Gulf of Mexico progress northward from Captiva through Pine Island Sound to Bokeelia (fig. 4D). Tidal range decreases from south to north. This decrease is particularly pronounced at low tidal stages. The overall reduction in tidal range is about 40 percent. As in the northern part of the estuarine system, phase lags for low tides (2-3 hours) are greater than phase lags for high tides (about 1 hour).

\section{Discharge at Inlets}

Discharges through each of the tidal inlets to the Charlotte Harbor estuarine system were measured for a 24-hour period during July 17-22, 1986, but were not measured synoptically because manpower and equipment that would have been required were not available. However, each was measured during similar spring-tide conditions. Measurement results indicate that maximum spring ebbflows are significantly greater than maximum floodflows at all passes except Gasparilla, probably because the number of measurements made at Gasparilla Pass was insufficient to determine the true maximum floodflow and ebbflow values. The measured flows indicate that the water transported through Boca Grande Pass is about twice the amount that is transported through San Carlos Pass and three to four times the amount of water transported through Captiva and Redfish Passes (table 3). Water transported through Blind Pass or Matlacha Pass is negligible, about 1 percent of the flow through Boca Grande Pass. 
Table 3. Summary of discharge measurements at tidal inlets $\left[\mathrm{ft}^{3} / \mathrm{s}\right.$, cubic foot per second]

\begin{tabular}{|c|c|c|c|c|c|c|}
\hline \multirow{2}{*}{$\begin{array}{c}\text { Site } \\
\text { number } \\
\text { (fig. 2) }\end{array}$} & \multirow[b]{2}{*}{ Name } & \multirow{2}{*}{$\begin{array}{l}\text { Measurement } \\
\text { period }\end{array}$} & \multicolumn{2}{|c|}{ Number of } & \multicolumn{2}{|c|}{$\begin{array}{c}\text { Maximum } \\
\text { discharge }\end{array}$} \\
\hline & & & $\begin{array}{l}\text { Verti- } \\
\text { cals }\end{array}$ & $\begin{array}{l}\text { Measure- } \\
\text { ments }\end{array}$ & $\begin{array}{l}\text { Flood } \\
\left(\mathrm{ft}^{3} / \mathrm{s}\right)\end{array}$ & $\left.\mathrm{Ebb}^{3} / \mathrm{s}\right)$ \\
\hline 9 & Gasparilla Pass & $\begin{array}{c}\text { July } 17-18,1986 \\
10: 47 \text { to } 08: 23\end{array}$ & 1 & 5 & 42,900 & 38,400 \\
\hline 10 & Boca Grande Pass & $\begin{array}{c}\text { July } 17-18,1986 \\
08: 58 \text { to } 06: 43\end{array}$ & $1_{5}$ & 22 & 300,000 & 464,000 \\
\hline 11 & Captiva Pass & $\begin{array}{c}\text { July } 21-22,1986 \\
09: 00 \text { to } 10: 00\end{array}$ & 3 & 25 & 91,400 & 120,000 \\
\hline 12 & Redfish Pass & $\begin{array}{c}\text { July } 21-22,1986 \\
09: 00 \text { to } 10: 00\end{array}$ & 1 & 21 & 97,600 & 117,000 \\
\hline 13 & Blind Pass & $\begin{array}{c}\text { July } 19-20,1986 \\
09: 10 \text { to } 08: 31\end{array}$ & 6 & 21 & 3,260 & 3,840 \\
\hline 14 & San Carlos Pass & $\begin{array}{c}\text { July } 21-22,1986 \\
09: 00 \text { to } 09: 00\end{array}$ & 5 & 24 & 155,000 & 228,000 \\
\hline 15 & Matlacha Pass & $\begin{array}{c}\text { July } 19-20,1986 \\
07: 41 \text { to } 06: 54\end{array}$ & 8 & 12 & 3,650 & 3,800 \\
\hline
\end{tabular}

${ }^{1}$ In addition, a "moving boat" technique was used at this site.

Similar measurement techniques were used at most of the passes. Anchored boats provided stable measurement platforms from which hydrographers measured velocity profiles at up to nine points in the vertical at intervals of 1 to 2 hours. Either Neil Brown ${ }^{1}$ model DRCM-2 acoustic velocity meters or MarshMcBirney model 527 electromagnetic current meters were used to obtain velocity and azimuth.

In addition to the anchored boats, other techniques also were used, depending upon the inlet. At Boca Grande Pass, a second boat moved sequentially between four additional points in the cross section so that velocity profiles could be taken; a third, specially outfitted "moving boat," continuously traversed the pass from bank to bank so that discharge measurements could be made. At Captiva Pass, three anchored boats were used. At Redfish Pass, miscellaneous velocity profiles were measured at quarterwidth points in the cross section in addition to those measured from the anchored boat. The technique at San Carlos Pass was identical to the technique for Boca Grande Pass, except that the moving boat was not used. At Blind Pass and Matlacha Pass, measurements were made from highway bridges and anchored boats were not used.

\section{Tidal Velocity}

Continuous point-velocity data were collected at nine sites in the study area for periods ranging from 5 to 25 days. Three of these sites were in the nearshore region of the Gulf of Mexico, three were in upper Charlotte Harbor, and three were in Pine Island Sound (fig. 2 and table 2). Eight Anderaa model RCM4 current meters and one General Oceanics model 6011 current meter, which are designed for submerged deployment and unattended operation, were used for this activity. The general deployment scheme for the Anderaa meters is shown in figure 5. 
Field experiments were run to determine how well the point velocities from these instruments would estimate the desired depth-averaged velocity and direction of flow. A series of velocity profiles were taken in the vicinity of each instrument during July 17-22, 1986. Statistical evaluations were made and the depth-averaged velocity and azimuth were computed from each profile (table 4).

\begin{tabular}{|c|c|c|c|c|c|c|c|c|}
\hline \multirow[b]{2}{*}{$\begin{array}{c}\text { Site } \\
\text { number } \\
(\mathrm{fig} .2)\end{array}$} & \multicolumn{2}{|c|}{$\begin{array}{c}\text { Distance above } \\
\text { bottom }\end{array}$} & \multirow[b]{2}{*}{$\mathbf{n}$} & \multicolumn{2}{|c|}{ Velocity } & \multicolumn{2}{|c|}{ Azimuth } & \multirow[b]{2}{*}{$\begin{array}{l}\text { Accuraçy } \\
\text { rating }\end{array}$} \\
\hline & Feet & Percentage & & $\begin{array}{c}\text { Mean } \\
\text { deviation }\end{array}$ & $\begin{array}{l}\text { Standard } \\
\text { deviation }{ }^{2} / S_{\max }\end{array}$ & $\begin{array}{c}\text { Mean } \\
\text { deviation } 1\end{array}$ & $\begin{array}{c}\text { Standard } \\
\text { deviation }\end{array}$ & \\
\hline $\begin{array}{l}\text { SI }-1 \\
\text { SI-2 } \\
\text { SI-3 } \\
\text { SI }-4\end{array}$ & $\begin{array}{l}1.9 \\
2.0 \\
2.0 \\
6.0\end{array}$ & $\begin{array}{l}14 \\
20 \\
14 \\
22\end{array}$ & $\begin{array}{l}7 \\
9 \\
7 \\
3\end{array}$ & $\begin{array}{r}0.19 \\
.18 \\
.28 \\
.46\end{array}$ & $\begin{array}{r}0.08 \\
.20 \\
.24 \\
.19\end{array}$ & $\begin{array}{r}30 \\
9 \\
13 \\
57\end{array}$ & $\begin{array}{r}18 \\
4 \\
11 \\
28\end{array}$ & $\begin{array}{l}\text { Poor } \\
\text { Fair } \\
\text { Fair } \\
\text { Poor }\end{array}$ \\
\hline $\begin{array}{r}S I-6 \\
S I-7 \\
S I-8 \\
S I-9 \\
S I-10\end{array}$ & $\begin{array}{l}2.0 \\
2.0 \\
2.0 \\
4.0 \\
2.0\end{array}$ & $\begin{array}{r}24 \\
24 \\
24 \\
15 \\
8\end{array}$ & $\begin{array}{r}8 \\
14 \\
5 \\
3 \\
3\end{array}$ & $\begin{array}{r}.08 \\
.10 \\
.05 \\
.26 \\
.36\end{array}$ & $\begin{array}{l}.05 \\
.09 \\
.03 \\
.06 \\
.18\end{array}$ & $\begin{array}{l}8 \\
5 \\
3 \\
4 \\
8\end{array}$ & $\begin{array}{l}7 \\
3 \\
4 \\
3 \\
6\end{array}$ & $\begin{array}{l}\text { Good } \\
\text { Good } \\
\text { Good } \\
\text { Fair } \\
\text { Fair }\end{array}$ \\
\hline
\end{tabular}

${ }^{1}$ Mean deviation $=\underline{\Sigma \mid \text { depth averaged value }- \text { point value } \mid}$

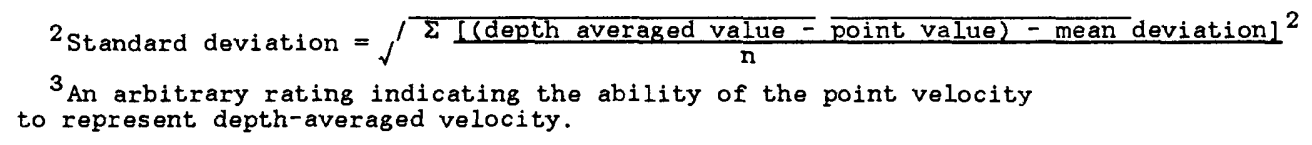

Values listed in table 4 represent measures of the mean and standard deviation of speed and direction differences between point and depth-averaged velocities at each site. The speed values have been referenced to the maximum measured at each site in order to allow for comparison between the sites. The smaller the values of mean and standard deviation are, the greater the confidence that the point velocity is a reliable estimator of the depthaveraged velocity. Data collected at sites SI-6, SI-7, and SI-8 seem to provide the best estimators of both speed and direction (table 4). Data collected at sites SI-1 and SI-4 are poor estimators, but the reasons for this are not known.

Both types of meters produced useful information, but the quality of the data deteriorated over time due to accumulations of barnacles and other fouling organisms. Barnacle accumulation had been anticipated, and the instruments initially had been coated with antifouling paint, but these precautions did not completely prevent accumulation. A summary of the usable periods of record from each instrument are presented in table 5. (Maximums and minimums are taken from that usable period.) At all sites the maximum velocities during flood tides were less than $1 \mathrm{ft} / \mathrm{s}$. During ebb tides maximum velocities were less than $1.25 \mathrm{ft} / \mathrm{s}$. These velocities are considerably lower than those measured in the tidal inlets. For example, in Redfish Pass, maximum velocity exceeded $6 \mathrm{ft} / \mathrm{s}$. 
Table 5. Summary of tidal-velocity measurments in Charlotte Harbor

[ft/s, foot per second; NA, record not available]

\begin{tabular}{|c|c|c|c|c|c|c|c|}
\hline \multirow{3}{*}{$\begin{array}{c}\text { Site } \\
\text { number } \\
\text { (fig. 2) } \\
\end{array}$} & \multirow{3}{*}{ Period of record } & \multicolumn{4}{|c|}{ Maximum velocity and azimuth } & \multirow{3}{*}{$\begin{array}{c}\text { Computed } \\
\text { Velocity } \\
\text { (ft/s) }\end{array}$} & \multirow{3}{*}{$\begin{array}{c}\text { residuals } \\
\text { Azimuth } \\
\text { (Degrees) }\end{array}$} \\
\hline & & $\frac{F}{f+/ s}$ & ood & $f+/ s$ & $\frac{b}{\text { Degrees }}$ & & \\
\hline & & $\mathrm{It} / \mathrm{s}$ & & $\mathrm{IL} / \mathrm{s}$ & & & \\
\hline SI-1 & $\begin{array}{l}\text { July } 9,1986 \text {, to } \\
\text { August } 6,1986\end{array}$ & 0.59 & 38 & 0.80 & 196 & 0.04 & 120 \\
\hline$S I-2$ & $\begin{array}{l}\text { July } 9,1986 \text {, to } \\
\text { July } 20,1986\end{array}$ & .86 & 11 & 1.08 & 185 & .08 & 156 \\
\hline$S I-3$ & $\begin{array}{l}\text { July 9, } 1986 \text {, to } \\
\text { August } 2,1986\end{array}$ & .81 & 5 & .51 & 200 & .13 & 26 \\
\hline SI-4 & $\begin{array}{l}\text { July } 10,1986 \text {, to } \\
\text { July } 15,1986\end{array}$ & .41 & NA & .30 & NA & NA & NA \\
\hline SI -6 & $\begin{array}{l}\text { July } 10,1986 \text {, to } \\
\text { July } 23,1986\end{array}$ & .70 & 7 & .60 & 200 & .05 & 4 \\
\hline $\mathrm{SI}-7$ & $\begin{array}{l}\text { July } 10,1986 \text {, to } \\
\text { July } 23,1986\end{array}$ & .90 & 122 & .67 & 267 & .08 & 81 \\
\hline SI-8 & $\begin{array}{l}\text { July } 16,1986 \text {, to } \\
\text { July } 20,1986\end{array}$ & .82 & 309 & 1.24 & 103 & .10 & 63 \\
\hline SI -9 & $\begin{array}{l}\text { July } 11,1986 \text {, to } \\
\text { July } 23,1986\end{array}$ & .43 & NA & .56 & NA & .09 & 48 \\
\hline SI-10 & $\begin{array}{l}\text { July } 11,1986 \text {, to } \\
\text { August } 9,1986\end{array}$ & .58 & 82 & .61 & 292 & .04 & 22 \\
\hline
\end{tabular}

Freshwater Inflow

Inflow to the estuary from the Myakka and Peace Rivers averages 630 $\mathrm{ft}^{3} / \mathrm{s}$ and 2,010 $\mathrm{ft}^{3} / \mathrm{s}$, respectively. Inflow from the Caloosahatchee River is about the same as inflow from the Peace River and averages between 1,900 and $2,100 \mathrm{ft}^{3} / \mathrm{s}$. Rain falling directly on the surface area of the harbor accounts for about $1,030 \mathrm{ft}^{3} / \mathrm{s}$ of freshwater inflow. Runoff from the barrier islands and coastal drainage area contributes an average of between 200 and $400 \mathrm{ft}^{3} / \mathrm{s}$.

Streamflows in the Peace and Myakka Rivers are largely unregulated and tend to correspond to rainfall patterns in the basins. Streamflow in the Caloosahatchee River also is influenced by rainfa11, but discharge to the estuarine system is effectively controlled by operation of Franklin Lock, structure S-79, about 27 miles upstream from the mouth. Several natural streams in the coastal drainage area and on the barrier islands have been widened and deepened to increase their capacity for drainage. In some areas along the harbor shoreline and on the barrier islands, waterfront homesites have been created by dredging canal systems. Water-control structures and salinity barriers have been built on some of the canals, which tend to affect the natural drainage and runoff characteristics of the coastal area and barrier islands.

Flow-duration curves for the Myakka, Peace, and Caloosahatchee River basins (fig. 6) are extrapolated for total drainage area from gaging-station analyses provided in Hammett (1990). The curves illustrate that the distribution of flows in all three basins is skewed. In a11 cases, the median (50-percent duration) flow is substantially less than the average flow, which indicates that the computation of average flow is significantly affected by infrequent high flows. For example, although the average flow for the Peace River basin is about $2,010 \mathrm{ft}^{3} / \mathrm{s}$ (Hammett, 1990), the median flow is about $660 \mathrm{ft}^{3} / \mathrm{s}$. This indicates that the computed average is not particularly representative of "typica1" flow conditions as flow is less than $660 \mathrm{ft}^{3} / \mathrm{s}$ 
50 percent of the time and is less than $2,010 \mathrm{ft}^{3} / \mathrm{s}$ about 75 percent of the time. The median flows from the three river basins are, therefore, a better estimate of typical flow.

\section{Salinity}

Estuaries are water bodies where inflow from freshwater tributaries mixes with tidally driven ocean water. Seasonal fluctuations in salinity primarily occur in response to seasonal fluctuations in freshwater inflow. Daily variations in salinity occur in response to tidal fluctuations, so that peak salinity occurs near floodtide stage and minimum salinity occurs near ebbtide stage. The daily range in salinity at a particular site generally increases with increased freshwater inflow. Salinity within the estuarine system is not areally constant, but increases with distance from freshwater-inflow sources. Density differences between freshwater and saltwater influence vertical salinity patterns, because fresh water tends to flow over denser saltwater. Depending on the interaction of water density with tidal forces, freshwater inflow, and wind, the estuary may exhibit a range of mixing characteristics from well mixed to highly stratified (fig. 7). Generally, an estuary tends to change from well mixed to highly stratified as freshwater inflow increases.

The salinity characteristics of the tidal Peace River, tidal Myakka River, and Charlotte Harbor estuarine system have been described by Stoker and others (1989), Hammett (1992), and Stoker (1992), respectively. The average high-tide location of the saltwater-freshwater interface (0.5-ppt 1ine of equal salinity) is about $14.5 \mathrm{mi}$ upstream from the mouth of the Myakka River and about $13 \mathrm{mi}$ upstream from the mouth of the Peace River. Saltwater extends to Frank1in Lock, structure S-79, about $27 \mathrm{mi}$ upstream from the mouth of the Caloosahatchee River and, during operation of the lock, has moved as far as 11 mi upstream from structure S-79 (Boggess, 1970).

Tidal mixing between Charlotte Harbor and the Gulf of Mexico is restricted by barrier islands. Salinity in the northern part of the estuarine system is typically lower along the western edge than along the eastern edge (Stoker, 1992). This pattern indicates that waters from the Peace and Myakka Rivers tend to mix with harbor waters and flow along the western edge, eventually exiting the harbor at Boca Grande Pass. Salinity in the southern part of the Charlotte Harbor estuarine system (Pine Island Sound, Matlacha Pass, and San Carlos Bay) generally is higher than in the northern part. Flow from the Peace, Myakka, and Caloosahatchee Rivers does not appear to influence salinity in Pine Island Sound and Matlacha Pass. Salinity in Matlacha Pass is lowest near the State Road 78 bridge because of freshwater inflow from Gator Slough and an adjacent canal system.

Although the average depth of the northern part of the estuarine system is only $9.3 \mathrm{ft}$ (table 1), vertical stratification occurs during moderate and high freshwater inflows and can persist for weeks after a high freshwater inflow event (Stoker, 1992). The degree of stratification is most significant at the northern and western parts of the upper harbor, although it has been observed to some degree throughout the upper harbor during high freshwater inflow. The southern part of the estuarine system tends to remain well mixed.

The relation between freshwater inflow from the Peace River and the vertical salinity gradient near site SI-1 (fig. 2) in the northern part of the upper harbor is shown in figure 8 . The degree of stratification is directly related to the quantity of freshwater entering the harbor from the Peace 
River. For two of the time periods on the graph, there are sufficient data to compute an estuarine Richardson number, which is a dimensionless measure of the balance between the buoyant forces (water density) and the turbulent mixing forces (tide, freshwater inflow, and wind). The higher the Richardson number, the greater the tendency toward vertical stratification. Fischer and others (1979) define an estuarine Richardson number of $\mathrm{R}=0.08$ as well mixed and $\mathrm{R}=0.80$ as stratified. The computation of the Richardson number for July $21,1982(\mathrm{R}=0.398)$, is subject to error because only a minimal amount of velocity data is available. Sufficient data were available to characterize the root mean square of the velocity component to the third power for the Richardson number for July $18,1986(R=0.315)$. This time period is considered to be a good indication of partially mixed conditions and because the tendency for stratification to occur is greatest at site SI-I, it is reasonable to assume that the entire estuarine system was partially-mixed to well-mixed during this time.

\section{HYDRODYNAMIC MODEL DEVELOPMENT FOR EXISTING CONDITIONS}

Hydrodynamic simulations were accomplished using SIMSYS2D, a twodimensional estuarine simulation system described by Leendertse and Gritton (1971). Equations that describe the physical laws governing water and constituent motion in two dimensions are applied at each location where simulated information is desired. These equations are solved at successive time steps to provide a close approximation of the time history of tidal stage, water transport, tidal velocity, and constituent transport at corresponding locations in the real system. The model has been applied successfully to other estuaries worldwide as well as to Tampa Bay and Hillsborough Bay on the west-central coast of Florida (Goodwin, 1987; 1991a).

\section{Governing Equations and Assumptions}

Water motion in estuaries is governed by the physical laws of conservation of mass and conservation of momentum. As applied in this study, SIMSYS2D uses vertically integrated forms of the equations that describe conservation of mass and conservation of momentum, as presented by Leendertse (1987, p. 6):

$$
\begin{aligned}
& \frac{\zeta}{t}+\frac{\partial(\mathrm{HU})}{\partial \mathrm{x}}+\frac{\partial(\mathrm{HV})}{\partial \mathrm{y}}=0 \\
& \frac{\partial \mathrm{U}}{\mathrm{t}}+\mathrm{U} \frac{\partial \mathrm{U}}{\partial \mathrm{x}}+\mathrm{V} \frac{\partial \mathrm{U}}{\partial \mathrm{y}}-\mathrm{fV} \\
& +\mathrm{g} \frac{\partial \zeta}{\partial \mathrm{x}}+\frac{\mathrm{g}}{2} \frac{\mathrm{H}}{\rho} \frac{\partial \rho}{\partial \mathrm{x}}+\mathrm{RU} \\
& -\frac{{ }_{\rho} \mathrm{a}^{2} \sin \Psi}{\rho \mathrm{H}}-\mathrm{k}\left[\frac{\partial^{2} \mathrm{U}}{\partial \mathrm{x}^{2}}+\frac{\partial^{2} \mathrm{U}}{\partial \mathrm{y}^{2}}\right]=0 \text {, } \\
& \frac{\partial V}{\partial t}+U \frac{\partial V}{\partial x}+V \frac{\partial V}{\partial y}+f U \\
& +\mathrm{g} \frac{\partial \zeta}{\partial \mathrm{y}}+\frac{\mathrm{g}}{2} \frac{\mathrm{H}}{\rho} \frac{\partial \rho}{\partial \mathrm{y}}+\mathrm{RV} \\
& -\frac{\Theta \rho \mathrm{W}^{2} \cos \Psi}{\rho \mathrm{H}}-\mathrm{k}\left[\frac{\partial^{2} \mathrm{~V}}{\partial \mathrm{x}^{2}}+\frac{\partial^{2} \mathrm{~V}}{\partial \mathrm{y}^{2}}\right]=0 \text {, }
\end{aligned}
$$


where $\mathrm{f}$ is the Coriolis parameter,

$g$ is the acceleration of gravity,

$h$ is the distance from the bottom to a reference plane,

$\mathrm{H}$ is the temporal depth $(=\mathrm{h}+\zeta)$,

$\mathrm{k}$ is the horizontal exchange coefficient,

$\mathrm{R}$ is the bottom stress coefficient,

$\mathrm{U}$ is $[1 /(\mathrm{h}+\zeta)] \int_{\mathrm{h}}^{\zeta} \mathrm{udz}$, vertically averaged velocity component in $\mathrm{x}$ direction,

$\mathrm{V}$ is $[1 /(\mathrm{h}+\zeta)] \int_{\mathrm{h}}^{\zeta} \mathrm{vdz}$, vertically averaged velocity component in $\mathrm{y}$ direction,

$W$ is wind speed,

$\zeta$ is the water-level elevation relative to a horizontal reference plane,

$\theta$ is the wind-stress coefficient,

$\rho$ is the density of water,

$\rho_{\mathrm{a}}$ is the density of air, and

$\Psi$ is the angle between wind direction and the positive y direction.

Equation 1 expresses conservation of mass in two dimensions. Equations 2 and 3 express conservation of momentum in the $\mathrm{x}$ - and $\mathrm{y}$ - Cartesian coordinate directions, respectively. Equations 1 through 3 are vertically integrated, or vertically averaged, throughout the water column. Vertical integration is valid if the vertically varying flow and transport can be adequately represented by a single value (in other words, flow is two-dimensional). However, estuarine circulation may have a three-dimensional structure. Longitudinal density gradients in estuaries may cause a nontidal circulation pattern with landward flow near the bottom and seaward flow near the water surface (Filadelfo and others, 1991; Smith and others, 1991). Two-dimensional models that include longitudinal density gradients in the equations of motion are unable to reproduce the vertical structure of the circulation, but they are able to reproduce the vertically integrated circulation patterns observed in well-mixed and partially-mixed estuaries (McAnally and others, 1984; Smith and Cheng, 1987; Jin and Raney, 1991). The model used in this study includes longitudinal density (or baroclinic) effects in equations 2 and 3 . Vertical density stratification is another physical condition that invalidates vertical averaging. As previously shown (fig. 8), vertical density stratification was not significant for the hydrologic conditions of this study. Wind may generate a surface flow with the wind and a bottom return flow against the wind (Pritchard and Vieira, 1984; Hunter and Hearn, 1987) and could significantly affect circulation patterns (Smith and Cheng, 1987). This study does not consider wind-induced circulation.

Transport of dissolved constituents is governed by large-scale advective or translatory motion and by fine-scale dispersive or turbulent mixing. The transport simulation capability of SIMSYS2D allows for constituent sources and sinks, as given by Leendertse (1987, p. 6-7):

$$
\frac{\partial(\mathrm{HP})}{\partial t}+\frac{\partial(\mathrm{HUP})}{\partial \mathrm{x}}+\frac{\partial(\mathrm{HVP})}{\partial \mathrm{y}}+\frac{\partial\left(\mathrm{HD}_{\mathrm{x}} \partial \mathrm{P} / \partial_{\mathrm{x}}\right)}{\partial \mathrm{x}}+\frac{\partial\left(\mathrm{HD}_{\mathrm{y}} \partial \mathrm{P} / \partial \mathrm{y}\right)}{\partial \mathrm{y}}-\mathrm{S}=0,
$$

where $H, U$, and $V$ are the same as defined for equations 1,2 , and 3 , $\mathrm{D}_{\mathrm{x}}$ and $\mathrm{D}_{\mathrm{y}}$ are the diffusion coefficients of dissolved substances,

$P$ is the vector of dissolved constituent concentrations, and $S$ is the source of fluid with dissolved substances. 
As with the velocities $U$ and $V, P$ is the vertically integrated average mass concentration of the constituent given by

$$
\mathrm{P}=\frac{1}{\mathrm{H}} \int_{-\mathrm{h}}^{\zeta} \mathrm{P}_{\mathrm{A}} \mathrm{dz}
$$

where $\mathrm{H}, \mathrm{h}$, and $\zeta$ are the same as defined for equations $1,2,3$, and 4; and $\mathrm{P}_{\mathrm{A}}$ is the local mass concentration of constituent substance, $\mathrm{A}$.

Holley (1969, p. 628) reported that mass transport by longitudinal dispersion is often very small compared with mass transport by advection, except in regions of large constituent concentration gradients. Leendertse (1970, p. 13) concluded that small errors in assigning values to the longitudinal dispersion coefficient would not substantially change the solutions obtained. He assumed that dispersion could be adequately defined by two components: an isotropic component representing the effect of lateral mixing and a directional component approximating longitudinal effects. The dispersion coefficients, $D_{x}$ and $D_{y}$, used in SIMSYS2D are given by Leendertse
$(1970$, p. 14-15)

$$
\begin{aligned}
& \mathrm{D}_{\mathrm{x}}=\mathrm{dHU}_{\mathrm{g}}^{0.5} \mathrm{C}^{-1}+\mathrm{D}, \text { and } \\
& \mathrm{D}_{\mathrm{y}}=\mathrm{dHV}_{\mathrm{g}}{ }^{0.5} \mathrm{C}^{-1}+\mathrm{D},
\end{aligned}
$$

where $\mathrm{D}_{\mathrm{x}}, \mathrm{D}_{\mathrm{y}}, \mathrm{H}, \mathrm{U}, \mathrm{V}$, and $\mathrm{g}$ are the same as defined for equations $1,2,3$,

d is an empirical dimensionless constant similar to that presented by Elder (1959);

$C$ is the Chezy roughness coefficient; and

$\mathrm{D}_{\mathrm{w}}$ is the diffusion coefficient representing wave, wind, and lateral mixing effects.

Baroclinic effects are treated in the momentum equations by the density gradient terms

$$
\frac{\mathrm{g}}{2} \frac{\mathrm{H}}{\rho} \frac{\partial \rho}{\partial \mathrm{x}} \text { and } \frac{\mathrm{g}}{2} \frac{\mathrm{H}}{\rho} \frac{\partial \rho}{\partial \mathrm{y}}
$$

where $\mathrm{g}, \mathrm{H}$, and $\rho$ are the same as defined for equations 2 and 3 .

Densities are derived from salinity, water temperature, and an equation of state. Salinity is calculated as a conservative constituent in the transport equation (eq. 4), and temperature is assumed constant throughout the model area as it is only slightly related to density. The relation between salinity and density is provided by the following equation of state (Eckert, 1958, p. 250) and is applied throughout the time and space domain of the model area:

$$
\begin{aligned}
\rho= & {\left[5890+38 \mathrm{~T}-0.375 \mathrm{~T}^{2}+3 \mathrm{~s}\right] /\left[\left(1779.5=11.25 \mathrm{~T}-0.0745 \mathrm{~T}^{2}\right)\right.} \\
& \left.-(3.8+0.01 \mathrm{~T}) \mathrm{s}+0.698\left(5890+38 \mathrm{~T}-0.375 \mathrm{~T}^{2}+3 \mathrm{~s}\right)\right],
\end{aligned}
$$

where $\mathrm{T}$ is temperature, in degrees Celsius; and $s$ is salinity, in parts per thousand. 


\section{Numerical Methods}

Partial-differential equations 1 through 4 describe the general relations that exist between the forces that govern water motion and solute transport in estuaries. Because the equations cannot be solved analytically for most actual conditions, procedures have been devised that provide approximate solutions by using computers to perform enormous arrays of numerical computations.

The numerical procedure used in SIMSYS2D is described in detail by Leendertse (1987) and is summarized below. Equations 1 through 4 can be approximated over a region in time and space by a large number of finitedifference equations. Each difference equation is similar in form to the parent equation, but is applicable at only one point in time and space and is separated from all other points by finite time and space increments. Such a finite-difference approximation is valuable because, by using the approximation, a differential equation is reduced to a series of simultaneous algebraic equations involving quantities at defined locations. Each difference equation contains known and unknown terms. As long as the number of equations is equal to the number of unknown terms, the system is solvable. The method of solution for the unknown terms involves a point-to-point, iterative, stepwise procedure that incorporates previously computed values and input data as appropriate.

A space-staggered finite-difference grid scheme (fig. 9) is used in the SIMSYS2D mode1. Water levels $(\zeta)$ and solute mass density (P) are defined at integer values of $\underline{m}$ and $\underline{n}$. Water depths, referenced to sea level, are defined at points midway between integer values of $m$ and $n$. Velocities in the $x$ direction $(U)$ are defined at points midway between integer values of $m$ and at integer values of $\underline{n}$. Velocities in the $y$ direction (V) are defined at points midway between integer values of $\underline{n}$ and at integer values of $m$. The grid extends to the boundaries of the modeled area in the positive and negative $x$ and $y$ directions. On land areas, water depths ( $h$ ) are replaced by land altitudes $(-h)$, and water velocities are computed only at times when water levels exceed land altitudes. Time $(t)$ also is simulated in a stepwise manner, with computational elements defined at integer points and midway between integer points. Leendertse (1987) provides a complete description of how equations 1 through 4 are structured at each ( $x, y$, and $t$ ) point and how unknowns in each equation are solved. An overview of the solution scheme also is presented by Cheng and Casulli (1982, p. 1665).

\section{$\underline{\text { Schematization }}$}

The Charlotte Harbor estuarine system for which a SIMSYS2D model was developed is shown in figure 10. A single model of the entire system was undertaken rather than multiple models of various subareas so that tidal flow, circulation, and flushing between the subareas, as well as within the subareas, could be studied. 
The modeled area was subdivided into a $0.386-\mathrm{mi}^{2}\left(1-\mathrm{km}^{2}\right)$ grid. The computational grid extends 40 cells in the "M" direction and 74 cells in the "N" direction (fig. 10). This grid size adequately depicts important hydraulic features of Charlotte Harbor and maintains the size of the computational arrays at a reasonable level. A reduction in grid spacing by half would result in an eightfold increase in the computational time requirements. This increase is due to an increase in cell numbers by a factor of four and an increase in time by a factor of two because of the resulting need to cut the time step in half. Goodwin (1987) discusses potential effects that changes in grid size could have on model results. A time step of 3 minutes was used for the model runs for this study. The grid was oriented with the y-axis rotated 18.5 degrees west of due north to match the approximate orientation of the coastline and various islands within the modeled area. This orientation was used to minimize near-boundary problems arising from the space-staggered scheme of solving the finite-difference equations.

Various physical features of the Charlotte Harbor estuarine system must be provided as input to SIMSYS2D. The bottom configuration, defined as water depth at each grid cell, is the most important element in model development. The water depths define bottom shape characteristics that control how water is numerically distributed by the model. Existing detailed depth information was obtained from the National Ocean Survey (NOS) based on their surveys. Depths were derived from annotated "boat sheet" maps that were originally compiled at a scale of 1:10,000.

Depth determinations were made using manual techniques. The model grid was overlain on the NOS boat sheets, and an average depth was interpolated for each grid cell based on the depths annotated on the map. All depths were adjusted to sea level. Land altitudes for grid cells that were higher than mean high water were assigned a constant value of $-2.5 \mathrm{ft}$.

The shoreline is depicted as a no-flow boundary, except where tributary streams enter the harbor. A flooding and drying feature of the model simulates landward or seaward movement of the shoreline with changes in tidal stage by removing and replacing grid cells in the computation as they are dried and wetted during low and high tides. Tidal entrances were schematized using the barrier-cell feature of the model. The only exception was the tidal inlet at Blind Pass that was not modeled because of its size relative to the grid size and the negligible amount of flow transported through it (fig. 3 and table 3).

The lower reaches of the Myakka, Peace, and Caloosahatchee Rivers were included in the model implementation. Each of these rivers contributes freshwater inflow to the harbor and influences the tidal prism, which is the difference between the volume of water in the estuarine system at high and low tide. The extent that these rivers were schematized was determined by the grid scale. As much of each riverine reach as possible was included without producing excessive surface-area distortions. The upstream limit in each of the rivers was selected as the point where the channel constricts abruptly, even though it is known that some of the tidal prism is not being modeled and that saltwater often extends upstream from these constrictions. The cells representing the tidal rivers reflect an area somewhat larger than the surface area of the rivers, which provides a partial adjustment for the unmodeled tidal prism. For all of these reasons, the tidal rivers can be considered to be less well represented than the open-water areas of the estuarine system. 
The Caloosahatchee River was schematized with an exaggerated bend midway up the modeled reach to minimize the overall rectangular dimension of the model, thereby reducing the computational requirements and costs. The consequences of this alteration are minimal because the two-dimensioral characteristics of the Caloosahatchee River are not well represented by the grid. As noted previously, this reach was not included for the purpose of investigating its detailed flow characteristics, but rather to account for the effects of its tidal prism on tidal flows and circulation within Charlotte Harbor.

Fluctuations in tidal stage are the primary driving function that causes water motion in the harbor. Fluctuations in tidal stage are applied at the seaward boundary; the model then distributes water to and from sections of the estuary by solving the finite-difference equations for each designated time and space increment. Because of uncertainties in the tidal stage data across the boundary and the limitations of the finite-difference solution of the mass and momentum equations, model results in the vicinity of the seaward boundary are considered less reliable than the results a few grid cells away from the boundary. Based on results from previous estuarine simulation studies in west-central Florida (Goodwin, 1987 and 1991a), the seaward boundary was established about $5 \mathrm{mi}$ offshore from the barrier islands to ensure the reliability of results within the estuarine system.

\section{Calibration and Verification}

Calibration and verification steps precede any model application. During calibration, parameters that cannot be precisely measured in the field are adjusted so that simulated hydrodynamic features in the model match field observations of hydrodynamic features as closely as possible. During verification, field observations from another time period are compared with simulated hydrodynamic features, and the degree of similarity is defined statistically. No adjustment of parameters is made during verification.

The data used for model calibration were collected during July 17-22, 1986, and included continuous tidal-stage measurements at 8 sites; continuous measurement of tidal-current speed and direction at 9 sites; periodic measurement of vertical profiles of tidal-current speed and direction, salinity, and temperature at 24 sites; and tidal-cycle measurement of discharge through the tidal inlets. The locations of the measurement sites are shown in figure 2, and the period of record at each of the sites is shown in figure 11. The time period selected for calibration was based on the availability of the greatest amount of data, particularly measurements of discharge through the tidal inlets. This time period also includes the largest spring tides of the entire year.

The data used for model verification were collected July 9-16, 1986, and include continuous tidal-stage measurements at eight sites and continuous tidal velocity and direction at nine sites. Vertical profiles and tidal-inlet discharge are not available for the verification period. The data-collection period also includes a neap-tide period. Throughout the collection of calibration data and verification data, wind speeds at the Punta Gorda and Fort Myers weather stations were light and variable. The highest sustained wind for a 2 -hour period at Punta Gorda was 8 knots. Therefore, the calibration data and verification data were mostly a function of tidal and river forcing, with very little or no effect from wind. 
Before calibration could proceed through adjustment of model parameters, the tidal driving function at the boundary of the model needed to be defined. Measured tidal-stage data from shore-based stations at Venice, Cayo Costa, and Fort Myers Beach were used to produce the tidal driving function that existed at the seaward boundary. This process was largely trial-and-error in which the phase of the observed tidal-stage data was shifted earlier in time by 15or 30-minute increments and the amplitude was adjusted about the mean tide elevation by applying a multiplication factor. Simulated stage data at the shore-based stations were then compared to measured stage data. Adjustments to phase and amplitude were continued until the simulated stage at the shorebased stations accurately reproduced the observed data. The seaward boundary near Fort Myers Beach required a time shift of 30 minutes and a 5 -percent decrease in tidal amplitude. Near Cayo Costa, the timelag from the seaward boundary to the shore was 15 minutes; no change in amplitude was required. Near Venice, the timelag from the seaward boundary was 15 minutes and there was a 5-percent increase in amplitude. The boundary tide at the southwestern corner of the grid was determined by fractional combination of the boundary tides at Venice and Fort Myers Beach. The criteria for judging the best fractional combination was the production of a realistic offshore flow field with no apparent numerical artifacts, as well as general agreement with measured velocities at sites SI-9 and SI-10. The tidal driving function at the southwestern corner was finalized as 50 percent of the Venice record and 50 percent of the Fort Myers Beach record. The tidal driving function that was used for the calibration and verification time periods is shown in figure 12 .

Boundary conditions for the three major tributaries were set equal to freshwater inflows recorded at gaging stations during the calibration period. Recorded streamflows were adjusted using drainage-area ratios to account for additional inflow downstream from the monitoring stations. Freshwater inflows were 526, 1,728, and $1,616 \mathrm{ft}^{3} / \mathrm{s}$ for the Myakka, Peace, and Caloosahatchee River basins, respectively.

Configuration of the tidal inlets and modifications to roughness coefficients were the primary adjustments used to calibrate the model of the Charlotte Harbor estuarine system. Special grid cells called barriers can be used in SIMSYS2D to simulate hydraulic openings, such as tidal inlets, that are smaller than the grid width of $0.62 \mathrm{mi}$ (fig. 13). Initial values for the sill depth and width were derived from the fathometer-measured cross sections that are shown in figure 3. During calibration, the cross-sectional area of the passes was increased by as much as 15 percent and decreased by as much as 9 percent of the initial values. These percentages were estimated to be the probable range of field-measurement error. Tidal amplitude increased a maximum of 11 percent at Charlotte Harbor at Bokeelia (site 3, fig. 2) for the model simulations in which cross-sectional areas were modified. Optimal cross-sectional areas were determined by finding the best match between tidal stages and tidal-inlet discharges. The final barrier-cell depth and width for each of the tidal inlets in the calibrated model is tabulated in figure 13.

The bottom of the harbor was treated as an impermeable, fixed boundary that causes resistance to the free movement of water. Resistance increases as the roughness of the bottom material increases. Manning's $\underline{n}$ is an empirical coefficient of roughness that is assigned to each grid of the model. Goodwin (1987) provides a summary of $\mathrm{n}$ values that have been used in previous estuarine models. The previous modeling activities were used as a guide in selecting initial $\mathrm{n}$ values for Charlotte Harbor. Two intial values of roughness were specified in the model. An $\underline{n}$ of 0.022 was assigned for the 
deeper areas, such as offshore and in the passes and boat channels. An $\underline{n}$ of 0.028 was assigned for shallow tidal flats and harbor coastlines. These initial specifications proved to be optimal for most of the model grid. Only local adjustments were required in some areas to improve the match between tidal stage and discharge. An intermediate $\underline{n}$ value of 0.025 was assigned to some areas in the tidal rivers and adjacent to the inlets.

A level water surface was assumed throughout the harbor at the start of each model run at an altitude equal to the starting water level at the seaward boundary. The harbor was assumed to be motionless, and all tidal currents were set to zero. An initial salinity distribution was determined from Stoker (1992) for the freshwater inflow conditions that existed during the calibration and verification periods. About 12 hours were simulated before the effects of the assumed initial conditions disappeared and model computations accurately reflected real stage and current conditions. Circulation patterns were more sensitive, and about 24 hours were simulated before the effects of initial conditions disappeared. The first 12 to 24 hours of each simulation were considered a "start-up" period, and model computations during this period were disregarded.

For the calibration and verification periods, standard errors in simulated tidal stage averaged about $0.1 \mathrm{ft}$, or about 3 percent of the range in stage at the measurement sites (table 6). Agreement between observed and simulated stage data for the calibration and verification time periods is excellent throughout the modeled area, as shown in hydrographs for Ft. Myers Beach, Bokeelia, and E1 Jobean (fig. 14).

Because of the different orders of magnitude of discharge through the tidal inlets, the nominal standard errors provided the most meaningful comparison of simulation error between inlets. Nominal standard errors ranged from 0.03 at Captiva Pass to 0.10 at Gasparilla Pass (table 6). The fewest velocity profiles were measured in Gasparilla Pass (table 3 and fig. 15); consequently, the relatively large nominal standard error may be more a reflection of the small number of measurements than simulation error. The nominal standard errors computed for the inlet discharge for the Charlotte Harbor estuarine system were in the same range as nominal standard errors computed by Goodwin (1991b) for discharge simulated using a one-dimensional unsteady flow model in residential canals in Cape Coral, Fla.

Agreement between observed and simulated tidal-inlets discharge data is good despite the range in cross-sectional areas and velocities in the inlets (fig. 15). At all of the inlets simulated discharges have the same tidalphase characteristics as those observed in the field. The magnitude of simulated discharges was most accurate for Captiva Pass, which is a relatively narrow inlet with high velocities, and least accurate for San Carlos Pass, which is broad and shallow (fig. 15). Because of the substantial expense involved in making tidal-cycle measurements at the inlets, discharge was not measured during the period used for model verification.

The degree to which the model (calibrated to stage and inlet discharge) simulates observed tidal velocity characteristics at selected sites is illustrated by graphs that show the magnitude and direction of flow at a particular site (fig. 16). The angle of the graph line is the azimuth of the flow vector at a discrete point in time, and the length of the line represents the magnitude of the flow. Simulated velocity represents an average throughout the water column in one grid cell and is only an indication of 
Table 6. Standard errors between observed and computed tidal stage and inlet discharges for calibration and verification periods

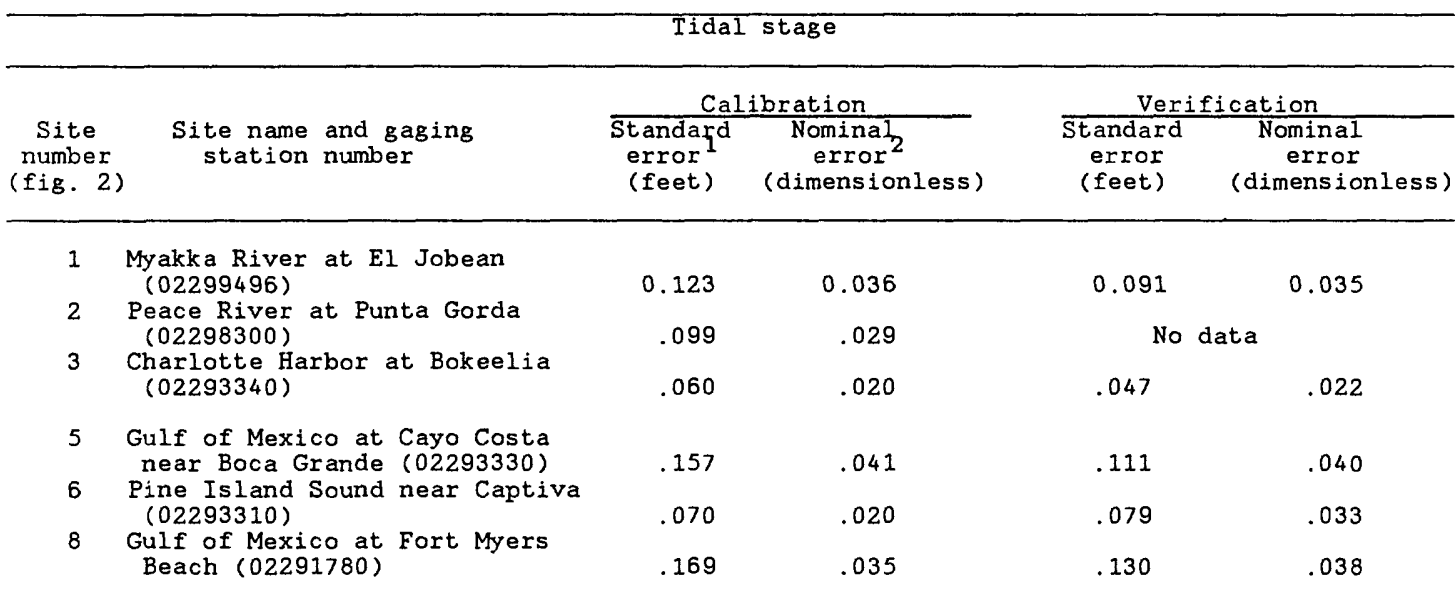

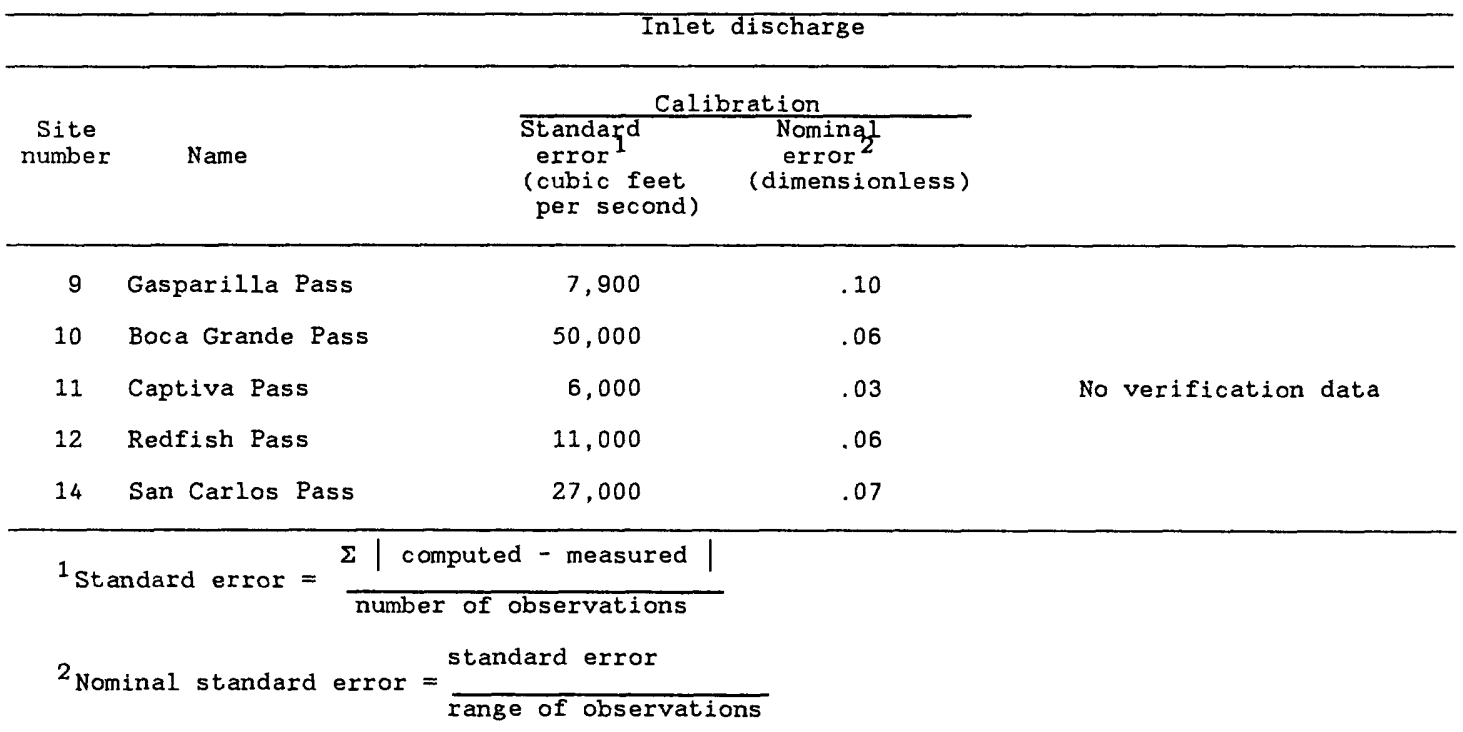

general velocity characteristics. Observed velocity is collected at a discrete point in space and is subject to many local influences that are not represented in the model. These influences include physical features such as small channels, depressions, shoals, and mounds that are not resolvable at the model scale, but often influence the distribution of velocity at that location. Because of local influences, discrete measurement points are not consistently reliable indicators of the general velocity characteristics.

Site SI-1 (fig. 2) is in northern Charlotte Harbor in an area of changing depths and converging river flows that create a complex lateral distribution of velocity. The graphs of velocity data (fig. 16) indicate considerable agreement between observed and simulated data. However, some observed velocity magnitudes were 50 percent greater than simulated magnitudes, and there were some deviations in azimuth of more than 30 degrees. There was a consistent tendency for flow reversal to occur earlier in the observed data than in the simulated data, which probably indicates that partially mixed conditions existed during field-data collection and that the near-bottom position of the meter ( $f i g .5$ ) resulted in quicker response to tidal influences. Had the meter been anchored nearer the surface, it could have been influenced by freshwater inflows for longer periods of time. 
Graphs of velocity data at sites SI-2 and SI- 3 are excellent examples to show the ability of the model to simulate water motion that was observed in the field. Simulated velocity magnitudes at SI-2 were slightly smaller than those that were observed, but there is good agreement between simulated and observed magnitude, direction, and phasing of tidal velocities at both sites. Agreement between simulated and observed data for site SI-6 also was good, although the magnitude of observed vectors is greater than that of simulated vectors. The bathymetry in the area of SI-6 is very complex, and the observed data were undoubtedly affected by local features that cannot be resolved at the scale modeleled.

In the middle of Pine Island Sound, site SI-7 is strongly influenced by flows through Redfish Pass. The simulated and observed data indicated the rotational nature of flow at this location. Generally, observed data had a greater magnitude than simulated data, which could have resulted from the proximity of the meter to the Intracoastal Waterway. Data collected at site SI- 8 were prone to measurement error because of local bathymetric features and the fact that the meter was disturbed after deployment. The two offshore sites, SI-9 and SI-10, had good phase comparisons, but the magnitude and direction of simulated flow at SI-9 were a poor representation of the observed tidal velocity, probably a result of the inability of the point velocity to accurately represent average velocity at the site. Comparisons between simulated and measured tidal-stage, inlet-discharge, and tidal-velocity data indicate that the model adequately simulates the hydrodynamic behavior of the Charlotte Harbor estuarine system and can be applied with some confidence to evaluate altered physical or hydrologic conditions.

\section{SIMULATION OF TIDAL-FLOW AND CIRCULATION CHARACTERISTICS}

Following calibration and verification, 65-day simulations were made for three conditions in the estuarine system. The first condition was defined as the baseline simulation and represented the existing physical configuration of the estuarine system, typical tidal patterns, and typical freshwater inflows from the tributary streams. The second condition represented the same physical configuration and tidal patterns as the baseline simulation, but had substantially reduced freshwater inflows from the tributaries. The third condition represented the same tidal patterns and freshwater inflows as the baseline simulation, but included modifications to represent physical conditions that might exist if parts of the Sanibel Causeway were removed. Tidal-flow and circulation patterns for these three conditions were analyzed from simulated output, and the results are presented in this section.

Harmonic analysis was applied to the measured tidal-stage data in order to develop a tidal-driving function for the seaward boundary of the model that could be used for the 65-day application runs. The tidal-driving function derived from harmonic components and the tidal-driving function derived from measured data for the calibration period were generated for Venice and Ft. Myers Beach (fig. 17). The tide generated from harmonic analysis closely emulates the measured tide at these sites.

Freshwater inflows used in the baseline simulation run were $526,1,728$, and 1,616 $\mathrm{ft}^{3} / \mathrm{s}$ for the Myakka, Peace, and Caloosahatchee River basins, respectively, and are the same as those used for the calibration period. Although these freshwater inflows are lower than computed average flows for 
the three tributary basins (Hammett, 1990), they are all higher than median flows. Consequently, the inflows used for the baseline simulation can be characterized as being nearer the high end of typical inflows.

For the reduced freshwater inflow condition, inflow from the Peace River basin was set at $420 \mathrm{ft}^{3} / \mathrm{s}$, which is the median flow, decreased to account for a potential trend in streamflow described by Hammett (1990). Inflows from the Myakka and Caloosahatchee River basins were reduced to $40 \mathrm{ft}^{3} / \mathrm{s}$ and $245 \mathrm{ft}^{3} / \mathrm{s}$, respectively. These inflows have been observed in the field and are hydrologically feasible, even without considering potential long-term changes in the inflow regimes.

Freshwater inflows for the simulation with parts of the Sanibel Causeway removed were the same as those used for the baseline simulation. To simulate the physical configuration that might exist if parts of the Sanibel Causeway were removed, two of the three barriers in the baseline configuration (fig. 13) were removed from the model and replaced with open cells. Depths for the open cells were taken from navigation charts that were prepared prior to construction of the causeway. The westernmost barrier (barrier 5, fig. 13) of the causeway was left in place because the spoil island it represents has been proposed for use as a recreation area.

\section{Lagrangian Particle Analysis}

One of the objectives of the Charlotte Harbor study is to use the mode 1 results to describe the tidal-flow and circulation characteristics of the Charlotte Harbor estuarine system. Tidal motion is the apparent water motion in an estuary, but the tidal motion masks the net water motion, which is typically much smaller than the tidal motion (Cheng and Casulli, 1982). The net water motion is often referred to as the residual circulation or nontidal circulation. Residual circulation drives long-term transport in an estuary, which is an important factor for determining the water quality and ecological condition of an estuary (Cheng and Casulli, 1982). Residual circulation can be calculated with either the Eulerian or the Lagrangian approach.

The Eulerian approach determines a nontidal average velocity at the model grid points by averaging the simulated velocities over a period of time that is longer than the tidal periods of interest (Goodwin, 1987). The result is an Eulerian average or residual velocity for which oscillatory tidal fluctuations are removed. Current-meter data that are averaged over a long period of time (table 5) represent an Eulerian residual velocity. Thus, Eulerian residual velocities are a useful method to compare measured and simulated velocities (Cheng and Casulli, 1982).

The Lagrangian approach tracks a fluid particle as the water velocity moves it through the estuary. Simulated Lagrangian particle tracks or residual velocities are not the same as measured or simulated Eulerian residual velocities (Cheng and Casulli, 1982; Ridderinkhof and Zimmerman, 1990). Eulerian analysis can only determine residual velocities at fixed points, whereas Lagrangian analysis is based upon a reference frame that moves at the same rate as the water velocity. Lagrangian particle tracks represent the transport process of advection, or transport by the water velocity, but do not represent the the transport process of dispersion (Schoellhamer and Jobson, 1986). The displacement of water mass and constituents in the water is a Lagrangian phenomenon, therefore, Lagrangian particle analysis was used to present simulation results for the Charlotte Harbor estuarine system. 
The continuous track of an example particle in Charlotte Harbor demonstrates the Lagrangian approach (fig. 18). The thin line represents the continuous particle track during the simulation, the symbol indicates the position of the particle at high tide, and the thick line is the track of the particle considering only high-tide positions. The example particle is injected at a high-tide position (first symbol). The tide then ebbs and floods and the particle moves to the second high-tide position, which is slightly closer to the inlet. After two more tide cycles, the tidal excursion distance increases as the particle approaches the inlet. The displacement of the high-tide particle positions also increases, which indicates that the residual velocity of the particle is increasing. The high-tide particle track can cross overland as a result of connecting the high-tide positions, but the particle does not actually move through land. Eventually, the particle exits the estuary through the inlet and enters the gulf. Once in the gulf, the example particle is transported out of the model domain. Velocity information was not available outside the model domain, so the particle position could not be determined once the model boundary was reached. The tracks that are presented were terminated at the last high-tide position in the model domain.

Limitations of the model and of particle injection need to be considered when interpreting Lagrangian particle tracks. The particle tracks are only as accurate as the simulated depth-averaged velocities. If the simulated depthaveraged velocities are inaccurate or if depth-averaging is not appropriate, then the particle tracks will not be accurate. At shorelines, the model prohibits flow perpendicular to the shoreline (cross-shore flow) and permits only tangential (or longshore) flow. Thus, particles that are very close to a shoreline may tend to travel parallel to the shoreline for an unreasonably long period of time. Finally, Lagrangian particle tracks are sensitive to the time of injection and initial position (Ridderinkhof and Zimmerman, 1990). The sequential particle injections are used to discuss the sensitivity of the model to the initial particle position.

Lagrangian particles were added to each of the three 65-day simulations. After the first 36 hours of simulated time, 157 particles (particle numbers 1 157) were synoptically added to the model domain at every fourth grid point so that the initial particle distribution was staggered like a checkerboard with a spacing of about $2.5 \mathrm{mi}$. The tide at this time was a lower-high slack tide at the neap location of the spring-neap cycle. In addition to the synoptically injected particles, sequential particle injections (particle numbers 158-205) at the mouths of the Caloosahatchee, Myakka, and Peace Rivers and Gator Slough were made at 2-hour intervals beginning from 168 hours (7 days) after the simulations began until 192 hours ( 8 days) after the simulations began. The particles were then transported in the model domain based upon the simulated water velocities.

\section{Baseline Simulation}

Typical flow patterns during floodtide and ebbtide are shown by simulated water-transport vectors in figures 19 and 20 . The vector lengths are scaled to represent the volumetric rate of transport in cubic feet per second. Southerly and easterly offshore flow directions are predominant during floodtide, whereas northerly and westerly offshore flow directions are predominant during ebbtide. The vectors indicate that large floodflows and ebbflows through Boca Grande Pass satisfy the tidal prism in upper and lower Charlotte Harbor and the upper part of Matlacha Pass, but contribute little to Gasparilla Sound and Pine Island Sound. Large floodflows and ebbflows through 
San Carlos Pass satisfy the tidal prism in the Caloosahatchee River, San Carlos Bay, the lower part of Matlacha Pass, and the lower extremity of Pine Island Sound. Flows through Gasparilla Pass have effects that appear to be limited to Gasparilla Sound.

There are areas of Pine Island Sound, Gasparilla Sound, and Matlacha Pass that have very low or no water transport (figs. 19 and 20). For the highslack-tide and low-slack-tide periods, however, there is some water transport through Pine Island Sound. During near high-slack tide (fig. 21), there is a northerly flow from San Carlos Bay, through Pine Island Sound, and into lower Charlotte Harbor. During near low-slack-tide conditions (fig. 22), there is a smaller but perceptible southward drift through Pine Island Sound.

Offshore vector directions in the southern part of the modeled area in figures 21 and 22 are opposite to the offshore vectors in figures 19 and 20 , respectively. This indicates that while floodflows are occurring landward of the barrier islands, the tide is reversing or has reversed direction in the Gulf of Mexico. This observation is consistent with tidal-stage information shown in figures $4 \mathrm{C}$ and $4 \mathrm{D}$, which indicates that tides in the gulf precede those within the estuarine system.

Circulation patterns for baseline simulation of typical freshwater inflow are shown by selected high-tide particle tracks from different subareas of the estuarine system (fig. 23A - 26A). Selected tracks for particles that were synoptically injected 1.5 days after the simulation began are shown in figures $23 \mathrm{~A}$ through 25A; figure 26A shows selected tracks for particles that were sequentially injected during the eighth day of the simulation. The particle tracks begin with the initial high-tide position and continue until either the particle leaves the model domain or until 40.0 days after the start of the simulation. Particle tracking continued throughout the 65 -day simulation, but 40.0 days was selected as the maximum length of the tracking plots so that the individual paths were more clearly distinguishable.

Particles that were injected in the Peace and Myakka Rivers moved seaward toward Boca Grande Pass either along the east or west side of upper Charlotte Harbor (particles 142 and 146, fig. 23A). Particle 147 (fig. 24A) was injected at the same time as particle 146 , but about $2.5 \mathrm{mi}$ from it. Although both particles were injected near the mouth of the Peace River, particle 147 first moved westward to the mouth of the Myakka River and then southward along the western shore. This example indicates that particle tracks are sensitive to the initial spatial positions of the particles even when the particles are injected into a relatively narrow feature, such as a river.

The particles injected sequentially at the mouths of the Myakka and Peace Rivers also followed tracks similar to particles 142 and 146, respectively (fig. 23A). However, when a particle was injected near the mouth of the Peace River during the first half of an ebbtide, it traveled the western shore of upper Charlotte Harbor, similar to the movement of particle 147. For example, particle 175 (fig. 26A) was injected during a floodtide 7.33 days after the simulation began and moved southward along the eastern shore, as did most of the sequentially injected particles. But particle 187, injected during the first half of an ebbtide 7.58 days after the simulation began ( 6 hours after particle 175 was injected), traveled to the western shore before moving to the south. This western track was followed by all of the particles injected at the mouth of the Peace River during the first half of an ebbtide and demonstrates the dependence of a particle track on the time of particle 
injection. Comparison of the particle displacements along the western shore (particles 142, 147, and 187) with those along the eastern shore (particles 146 and 175) indicates that the southerly residual velocity was greater along the western shore.

The seaward residual velocities of the particles were greater on the western shore than on the eastern shore. A 6.2-mi-long reach of the upper harbor (along the nearly north-south axis of the model grid and centered across from Gasparilla Pass) was selected for computation of average residual particle velocities. Particles 142 (fig. 23A) and 147 (fig. 24A) that were near the western shore of the upper harbor had an average residual velocity of $0.056 \mathrm{ft} / \mathrm{s}$ in the reach. On the eastern shore, particles 146 (fig. 23A) and 175 (fig. 26A) had an average residual velocity of $0.043 \mathrm{ft} / \mathrm{s}$ in the reach.

The flow pattern along the western and eastern shores of upper Charlotte Harbor was seaward, but the flow in the center channel of the harbor was landward. The high-tide position of particle 113 (fig. 23A), which was injected in southern upper Charlotte Harbor, moved to the north relatively slowly, and, eventually, its high-tide position during typical freshwater inflow was virtually stationary. Particle 113 was still oscillating with the tidal velocity, which is greater in the center channel of the upper harbor than near the shore (figs. 19 and 20), but it returned to virtually the same position near the middle of upper Charlotte Harbor at every high tide. The end of the plotted track (fig. 23A) represents the particle position 40.0 days after the simulation began, but the high-tide position of particle 113 remained at the same point for the remainder of the 65-day simulation. Similarly, particle 98 (fig. 24A) was injected near the middle of lower Charlotte Harbor, moved east, and then north into upper Charlotte Harbor. Upon reaching the northern part of the upper harbor, particle 98 turned to the west and began moving south along the western shore. Thus, particle 98 moved counter clockwise around the residual stagnation zone in which particle 113 had become trapped. Because wind-induced circulation and vertical velocity profiles created by gravitational circulation were not simulated, it is possible that the residual stagnation zone characterized by particle 113 is an artifact of the model.

Circulation in Lower Charlotte Harbor is strongly influenced by the tidal exchange through Boca Grande Pass. The high velocities near the pass (figs. 19 and 20) cause major displacements of high-tide particle positions. For example, particles 142 and 146 (fig. 23A), particles 70 and 147 (fig. 24A), and particles 91 and 96 (fig. 25A) all had significant displacements of their high-tide position when they reached the west-central part of lower Charlotte Harbor near Boca Grande Pass. Particle 70 left the model domain 6.3 days after injection in northern Pine Island Sound, and particle 146 left the model domain 38.3 days after injection at the mouth of the Peace River. Particle 91 started in Gasparilla Sound, entered the Gulf of Mexico through Gasparilla Pass, moved southward, entered and exited lower Charlotte Harbor through Boca Grande Pass, and continued southward in the gulf until it left the model domain west of Sanibel Island 28.9 days after injection. Particles 96, 142, and 147 were still in the model domain at the conclusion of the 65-day simulations.

Some particles remained in lower Charlotte Harbor for a relatively long period of time before reaching the area where there was significant influence from Boca Grande Pass. Particles 142 and 146 (fig. 23A), and particle 147 (fig. 24A), are examples. Particles 98 and 137 (fig. 24A) and particles 175 
and 187 (fig. 26A) were not directly influenced by the tidal exchange through the pass. These particles were in the southern, northern, or eastern part of lower Charlotte Harbor. Particle 98 was not initially influenced by the tidal exchange through Boca Grande Pass and was carried by a landward residual flow into upper Charlotte Harbor. Particle 96 (fig. 25A) was initially influenced by Boca Grande Pass, but then moved toward the eastern shore of lower Charlotte Harbor, similar to the movement of particle 98, and turned clockwise to the south as it moved westward in the southern lower harbor. Particles 142, 147, and 187 in the northern part of the lower harbor also moved westward. Thus, the residual flow pattern in the eastern half of the lower harbor is similar to that in the upper harbor with a seaward residual flow near the shorelines and a landward residual flow in the center channel. Particle 137 (fig. 26A) is an example of a particle track that parallels a shoreline due to a lack of a cross-shore velocity component as it moves tangentially around the northern part of Pine Island from Matlacha Pass through the lower harbor and into nothern Pine Island Sound.

In Charlotte Harbor, the landward residual flow in the relatively deep center channel and the seaward residual flow along the shorelines is probably caused by the presence of Boca Grande Pass and enhanced by inertia and friction. During floodtide, flow follows the deep channel from the pass through the lower harbor and north into the upper harbor (fig. 19). During ebbtide, the flow through Boca Grande Pass is more uniform than during floodtide. The net result is a landward residual flow in the deep channel and a seaward residual flow near the shorelines as indicated by the preceding particle track analyses. This type of inlet-induced residual flow has been presented by Stommel and Farmer (1952) and Fischer and others (1979). In addition, the inertia of the floodtide flow in the deep channel may enhance the landward residual by prolonging the floodtide and shortening the ebbtide in the channel. Conversely, the effect of bottom friction increases as the water depth decreases, thus prolonging the ebbtide and shortening the floodtide in the shallow water along the shoreline. Therefore, the landward residual flow in the deep channel and seaward residual flow near the shoreline may be enhanced by the net result of inertia in the deep channel and friction in shallow water.

Gasparilla Pass has much smaller tidal velocities (figs. 19 and 20) than Boca Grande Pass, and the particle displacements in Gasparilla Sound were smaller. Particle 97 ( $\mathrm{fig}$. 24A) started in the southeastern corner of Gasparilla Sound and slowly drifted northwest and into the Gulf of Mexico through Gasparilla Pass. Particle 91 (fig. 25A) started in the center of Gasparilla Sound and, compared to particle 97, quickly entered the Gulf of Mexico through Gasparilla Pass. The small residual flow toward Gasparilla Pass in Gasparilla Sound indicates that there is a small northwesterly residual flow into the sound from upper Charlotte Harbor. Because this northwesterly residual flow is small, none of the selected particles moved from the upper harbor into Gasparilla Sound.

Particles that were injected near the mouth of the Caloosahatchee River either traveled north into Pine Island Sound or southeast into the Gulf of Mexico through San Carlos Bay. Particle 150 (fig. 23A) traveled westward out of the Caloosahatchee River and turned north into Pine Island Sound. Most of the particles injected sequentially at the mouth of the Caloosahatchee River followed a similar track into Pine Island Sound. However, when a particle was injected during the first half of an ebbtide, the particle remained in San Carlos Bay before traveling to the southeast to enter the Gulf of Mexico. For example, particle 172 (fig. 26A), which was injected in the Caloosahatchee 
River during a floodtide 7.25 days after the simulation began, moved west and then north into Pine Island Sound, similar to the movement of particle 150 . Particle 184 (fig. 26A) was injected near the site of particle 172 and 6 hours later after the beginning of an ebbtide. The particle remained in San Carlos Bay about 2 weeks before entering the Gulf of Mexico and leaving the model domain 20.0 days after injection.

Particles in San Carlos Bay traveled to the southeast and entered the Gulf of Mexico. The high-tide position of particle 54 (fig. 23A) was initially near the southern boundary of San Carlos Bay. However, once the particle exited San Carlos Bay, it was quickly carried out of the model domain 8.9 days after injection. Particle 129 (fig. 24A), which was started farther north than particle 54, also moved southeast from San Carlos Bay into the Gulf of Mexico, but remained close to the shoreline and did not leave the model domain. The 12 particles that were sequentially injected at the mouth of the Caloosahatchee River remained in San Carlos Bay an average of 14.9 days.

The residual flow pattern in Pine Island Sound is northward. Particle 150 (fig. 23A) and particle 172 (fig. 26A) entered Pine Island Sound from the south with large high-tide position displacements that diminished as the particles moved northward. Particle 150 never left the model domain, but particle 172 entered the Gulf of Mexico through Captiva Pass and left the model domain west of Sanibel Island 54.25 days after injection at the mouth of the Caloosahatchee River.

As particles moved to the west in Pine Island Sound, they were more likely to enter the Gulf of Mexico through one of the passes. Particle 74 (fig. 24A), which started close to the end position of particle 150, slowly drifted northward until it turned west as it was influenced by Captiva Pass, accelerated, and entered the Gulf of Mexico through the pass. Similarly, particle 65 (fig. 25A) drifted northward, turned west, and accelerated as it entered the Gulf of Mexico through Redfish Pass. In the northern part of Pine Island Sound, particle 70 (fig. 24A) also moved northward and entered the Gulf of Mexico through Boca Grande Pass.

The residual flow in Matlacha Pass is northward. Particle 134 (fig. 23A) was injected at the southern end of Matlacha Pass, and its position during high tide slowly moved northward, although the high-tide position retreated southward during neap tide. The average residual velocity northward toward lower Charlotte Harbor was $0.005 \mathrm{ft} / \mathrm{s}$. This particle did not leave the model domain during the 65-day simulation. Particle 137 (fig. 24A) drifted slowly northward until it entered lower Charlotte Harbor with an average residual velocity of $0.014 \mathrm{ft} / \mathrm{s}$. Movement of this particle stagnated but did not reverse direction during neap tide. All particles injected sequentially at Gator Slough moved northward into the southeastern corner of lower Charlotte Harbor. Because the residual flow in Matlacha Pass is northward, water is probably entering Matlacha Pass from San Carlos Bay, but none of the selected particles followed this path because of the relatively small residual flow northward into Matlacha Pass.

The residual flow offshore in the Gulf of Mexico is southward. Particle 91 (fig. 25A) entered the Gulf of Mexico through Gasparilla Pass, moved southward, entered and exited lower Charlotte Harbor through Boca Grande Pass, and continued southward. Movement of this particle indicates that a water mass that enters the gulf through a northern pass (Gasparilla) can reenter the estuarine system through a more southerly pass (Boca Grande). Particles 74 
and 65 (figs. 24A and 25A), which entered the gulf through Captiva and Redfish Passes, respectively, moved to the south. Particles 54 and 129 (figs. 23A and 24A) that entered the gulf through San Carlos Bay also traveled southward.

\section{Reduced Freshwater Inflow Simulation}

The water-transport vectors for the reduced freshwater inflow simulation are similar to the water-transport vectors for the baseline simulation (figs. 19-22); therefore, they are not included in this report. There are large floodflows and ebbflows through Boca Grande Pass and San Carlos Pass and relatively small floodflows and ebbflows through Redfish and Captiva Passes. The areas of low or no water transport in Pine Island Sound, Gasparilla Sound, and Matlacha Pass in figures 19 and 20 also are present for reduced freshwater inflow.

The general residual circulation patterns for reduced freshwater inflow are similar to those for typical freshwater inflow, but some of the particle tracks in figures 23 through 26 differ. Although the general circulation characteristics of the estuarine system cannot be reliably deduced from the track of a single particle, tracks from multiple particles provide the information needed to make reasonable inferences about the general circulation patterns.

For the reduced freshwater inflow simulation, all particles released at the mouth of the Myakka River traveled south along the western shore of upper Charlotte Harbor, similar to the movement of particle 142 (fig. 23B). The residual velocity of particle 142 in the 6.2 -mi reach along the north-south axis of upper Charlotte Harbor was $0.056 \mathrm{ft} / \mathrm{s}$ for typical freshwater inflow, but decreased to $0.030 \mathrm{ft} / \mathrm{s}$ for reduced freshwater inflow. For typical freshwater inflow, all 12 particles sequentially injected at the mouth of the Myakka River passed the midpoint of the $6.2 \mathrm{mi}$ reach and had an average time of passage of 11.5 days following injection. For reduced freshwater inflow, only five of the particles passed the midpoint, with an average time of passage of at least 56.3 days. The exact length of time could not be determined because 7 of the 12 particles stagnated near the mouth of the river and did not pass the midpoint of the reach during the 65-day simulation. None of the particles left the model domain during the simulation. Thus, the residence time of water from the Myakka River in the upper harbor is at least five times greater for reduced freshwater inflow than for typical freshwater inflow.

Particles injected at the mouth of the Peace River moved southward through the upper harbor, either along the western or eastern shore. The high-tide position of particle 146 ( $f i g$. 23B) remained in the vicinity of the mouth of the Peace River 22 days before the particle moved west and then south along the western shore. Particle 147 ( $f i g .24 B$ ) followed a similar track, except it moved more rapidly. Both of these synoptically injected particles traveled to the western shore before they turned to the south, but all of the sequentially injected particles moved to the south along the eastern shore of the upper harbor, similar to particles 175 and 187 (fig. 26B). When particles 146, 175, and 187 were in the $6.2-\mathrm{mi}$ reach and along the eastern shore of the upper harbor, the average residual velocity was $0.043 \mathrm{ft} / \mathrm{s}$ for typical freshwater inflow and $0.019 \mathrm{ft} / \mathrm{s}$ for reduced freshwater inflow. 
For typical freshwater inflow, one of the 12 particles injected sequentially at the mouth of the Peace River did not pass the midpoint of the $6.2-\mathrm{mi}$ reach, and the average time of passage for those that did pass the midpoint was 19.5 days. Three particles left the model domain during the 65day simulation. For reduced freshwater inflow, four particles did not pass the midpoint, and the average time of passage for those that did was 35.2 days; none of the particles left the model domain during the 65-day simulation. The residual velocity and time-of-passage calculations indicate that seaward residual flow is slower for reduced freshwater inflow. Water from the Peace River remains in the upper harbor about twice as long for reduced freshwater inflow as for typical freshwater inflow.

The effect of reduced freshwater inflow on the landward residual flow in the deep center channel of upper Charlotte Harbor cannot be clearly determined from the particle tracks. Particle 113 (fig. 23A) was trapped in a residual stagnation point for typical freshwater inflow, but for reduced freshwater inflow, particle 113 (fig. 23B) started at the southern end of the upper harbor and moved north before it turned counterclockwise and moved south with the western shore seaward residual current. Particle 98 (fig. 24A) moved toward the western shore for typical freshwater inflow but toward the eastern shore for reduced freshwater inflow (fig. 24B). Particle 96 (fig. 25A) did not move into the upper harbor for typical freshwater inflow, but after 40 days of simulation time for reduced freshwater inflow, particle 96 moved near the northern edge of the upper harbor (fig. 25B). Neither particle 96 nor particle 98 left the model domain during the 65-day simulation of reduced freshwater inflow. Thus, the landward residual flow in the deep channel of the upper harbor is present for both typical and reduced freshwater inflow, but the effect of reducing the freshwater inflow on this circulation feature cannot be determined from the available particle tracks.

For typical and reduced freshwater inflow simulations, lower Charlotte Harbor is strongly influenced by the tidal exchange through Boca Grande Pass. Landward residual flow in the deep center channel is demonstrated by particle 98 (fig. 24A and B). Particle 96 (fig. 25B) had a landward residual flow into upper Charlotte Harbor for reduced freshwater inflow, but during typical freshwater inflow, this particle was turned back toward the west as it approached the eastern shore of the harbor (fig. 25A). Particle 91 (fig. 25A and $B$ ) followed the same initial path for both inflow conditions, but for reduced freshwater inflow, it exited the model domain west of Boca Grande Pass 20.3 days after injection. For typical freshwater inflow, however, particle 91 moved southward in the gulf after exiting through Boca Grande Pass. Conversely, particle 70 (fig. 24A) exited the model domain west of Boca Grande Pass for typical freshwater inflow, but for reduced freshwater inflow, the particle migrated southward in the gulf after exiting through Boca Grande Pass, reentered the estuarine system through Captiva Pass, exited back to the gulf, and continued southward until it left the model domain.

Residual circulation in Gasparilla Sound is toward Gasparilla Pass. Tidal velocities within Gasparilla Sound, however, are much slower than in other parts of Charlotte Harbor (figs. 19-22), and, when freshwater inflow is reduced, the tidal velocities, as shown through movements such as particle 97 (fig. 24B), are even slower. Particle 97 did not leave the model domain during the 65-day simulation. The small residual flow toward Gasparilla Pass in Gasparilla Sound indicates that there is a small northwesterly residual 
flow into the sound from upper Charlotte Harbor. However, for typical and reduced freshwater inflow, the northwesterly residual flow is so small that no particles moved from the upper harbor into the sound.

The reduction of freshwater inflow from the Caloosahatchee River slightly increased the residence time of particles in San Carlos Bay. For typical freshwater inflow, particle 129 (fig. 24A) was injected into San Carlos Bay and moved out of the bay through San Carlos Pass within a few tidal cycles. However, for reduced freshwater inflow, particle 129 did not exit through San Carlos Bay, but instead moved into the Caloosahatchee River, returned to San Carlos Bay, and finally entered Pine Island Sound (fig. 24B). The 12 particles injected sequentially at the mouth of the Caloosahatchee River remained in San Carlos Bay an average of 14.9 days for typical freshwater inflow and an average of 16.1 days for reduced freshwater inflow. Particles 172 and 184 (fig. 26A and B) are examples of this movement.

Reduction of freshwater inflow seems to have a minimal effect on residual flow in Pine Island Sound. Particle 74 (fig. 24A and B) was injected into Pine Island Sound and followed a similar track for both freshwater inflow conditions. For typical freshwater inflow, this particle exited the sound through Captiva Pass 23.0 days after injection, and, for reduced freshwater inflow, the particle exited 26.2 days after injection. Particle 65 (fig. 25A and $B$ ) followed similar tracks for both inflow conductions, exiting Pine Island Sound through Redfish Pass 10.1 days after injection during the typical freshwater inflow simulation and 9.1 days after injection during the reduced inflow simulation. Particle 150 (fig. 23A) followed a slightly different track for the reduced freshwater inflow case than for the typical freshwater inflow case and entered Pine Island Sound in shallower water. This difference in the initial shallower position in the sound also affected the ultimate movement of particle 150 for reduced freshwater inflow.

The northward residual flow in Matlacha Pass was slightly greater for the reduced freshwater inflow simulation than for the typical freshwater inflow simulation. Particle 134 (fig. 23A and B) was injected in southern Matlacha Pass and moved farther north for the reduced freshwater inflow simulation than for typical freshwater inflow simulation. The average residual velocity of particle 134 was $0.005 \mathrm{ft} / \mathrm{s}$ for typical freshwater inflow and $0.006 \mathrm{ft} / \mathrm{s}$ for reduced freshwater inflow. Particle 137 ( $\mathrm{fig} .24 \mathrm{~A}$ and $\mathrm{B}$ ) was injected in the middle of Matlacha Pass and moved to the north for both freshwater inflow conditions. The average residual velocity of particle 137 while in Matlacha Pass was $0.014 \mathrm{ft} / \mathrm{s}$ for typical freshwater inflow and $0.015 \mathrm{ft} / \mathrm{s}$ for reduced freshwater inflow. Because the residual flow in Matlacha Pass is southward during neap tide and generally is more northerly when freshwater inflow is reduced, the residual flow seems to be a combination of a southerly riverine component that is dependent on the freshwater inflow and a northerly tidal component that is dependent on the spring-neap cycle.

\section{Simulation Without Sanibel Causeway}

The model was used to investigate the change in residual circulation caused by the simulated removal of the Sanibel Causeway for typical freshwater inflow conditions. The magnitude and direction of water-transport vectors for this new model configuration generally are similar to those presented in figures 19 through 22. The only exception is at the causeway site where removal of the causeway produces a more uniform water-transport profile through San Carlos Pass than is shown on figures 19 through 22. 
The selected particles and end time for this simulation (40.0 days after the simulation began) are the same as those used in the previous models. The particle tracks for typical freshwater inflow with the causeway are presented as figures 23A through $26 \mathrm{~A}$ and are repeated as figures $27 \mathrm{~A}$ through $30 \mathrm{~A}$ to offer an easy comparison of the effect of the causeway removal on particle tracks (figs. 27B-30B). The general residual circulation patterns with and without the causeway are similar, but some of the particle tracks differ.

The Sanibel Causeway has little effect on the residual circulation in upper and lower Charlotte Harbor. The general pattern of seaward residual flow along the shoreline and landward residual flow in the deep center channel is the same with or without the causeway. The particle tracks in upper and lower Charlotte Harbor (figs. 27-30) are similar, if not nearly identical.

The residual flow in Gasparilla Sound is only slightly affected by the Sanibel Causeway. Particle 97 (fig. 28A and B) followed a nearly identical track while in the sound, but small differences in the flow patterns caused it to exit the sound differently. With the causeway, this particle exited the sound and stagnated near Gasparilla Pass, possibly because it was close to a shoreline, which would prevent cross-shore motion. Without the causeway, this particle did not stagnate near the shoreline, moved south, and entered lower Charlotte Harbor through Boca Grande Pass. The southerly movement in the gulf and reentry into the estuarine system through a pass farther south is a characteristic that was discussed previously. The tracks for particle 91 (fig. 29A and B) are similar with or without the causeway.

Removal of the causeway affected the tracks of some particles that were injected at the mouth of the Caloosahatchee River, but consistent changes in residence times or residual flow patterns were not observed in San Carlos Bay. With the causeway in place, particle 54 (fig. 27A) left the model domain just west of Fort Myers Beach 8 days after injection. Without the causeway, particle 54 stagnated adjacent to the beach and did not leave the model domain (fig. 27B). The reverse occurred for particle 129 (fig. 28A and B); the particle stagnated with the causeway and it exited the model domain without the causeway. For particles synoptically injected into San Carlos Bay, the computed average residence time was 6.3 days, with or without the causeway. With the causeway removed, 12 particles that were sequentially injected at the mouth of the Caloosahatchee River moved into Pine Island Sound similar to the movement of particles 172 and 184 (fig. 30B). With the causeway in place, particle 184 never passed into Pine Island Sound, but exited south from San Carlos Bay directly into the Gulf of Mexico. Of the 12 particles sequentially injected, the residence time of 8 particles in San Carlos Bay decreased with removal of the causeway, 1 was unchanged, and 3 increased.

The particle tracks in Pine Island Sound did not conclusively indicate any effect of removing the causeway on the northerly residual flow. Without the causeway, particle 150 (fig. 27B) moved north more rapidly in Pine Island Sound, and particle 172 (fig. 30B) exited the sound more quickly than with the causeway in place. However, particle 65 (fig. 29B) remained in the sound 6.3 days longer without the causeway. In the northern part of the sound, the tracks of particles 70 and 74 (fig. 28B) were not significantly affected by removing the causeway. Ten particles were synoptically injected in Pine Island Sound south of Redfish Pass. Removal of the causeway increased the residence time of two particles, decreased the residence time of four particles, and did not affect the residence time of four particles, one of 
which did not leave the sound during either simulation. The computed average residence time in the sound for particles that were injected south of Redfish Pass was 15.2 days with the causeway and 15.5 days without the causeway.

The northward residual flow in Matlacha Pass was not significantly affected by removing the Sanibel Causeway. The track of particle 134 (fig. $27 \mathrm{~A}$ and $\mathrm{B}$ ) was virtually the same with or without the causeway. Without the causeway, particle 137 (fig. 28B) followed a track similar to its track with the causeway in place until it reached northeastern Pine Island. Particle 137 moved out of Matlacha Pass and into lower Charlotte Harbor with the causeway in place (fig. 28A), and stagnated at the shoreline of Pine Island without the causeway. As mentioned previously, a small difference in water velocity that is not associated with a significant difference in residual circulation can shift the track of a particle slightly so that it stagnates against a shoreline. This seems to be the case for particle 137.

\section{SIMULATION OF FLUSHING CHARACTERISTICS}

The flushing characteristics of Charlotte Harbor were determined by simulating the motion of conservative constituents in the estuary. A conservative constituent does not decay with time or react with other constituents, so the transport of a conservative constituent is determined only by the processes of advection and dispersion. Advection is the movement of a constituent with the mean water velocity, and dispersion is the tendency of a constituent to spread due to water velocity fluctuations about the mean velocity. In the previous section, the residual circulation was determined by studying the advective characteristics of discrete Lagrangian water particles. Simulation of conservative constituents is better suited for determining flushing characteristics because the conservative constituent can be injected uniformly in a subarea of the estuary instead of at discrete points. The process of dispersion is included in the constituent transport equation (eq. 4).

A series of numerical experiments were made in which elevated concentrations of a simulated conservative dye were imposed on several different parts of the modeled flow system at the beginning of the 65-day simulation period. For each of the three 65-day simulations, dye was injected in one of four subareas of Charlotte Harbor (fig. 1): upper Charlotte Harbor, lower Charlotte Harbor (including Gasparilla Sound), Pine Island Sound, and San Carlos Bay. The elevated concentration for each injection was set at a value of 2.0 units (which can be interpreted as a mass per unit volume, such as milligrams per liter), and the remainder of the simulated water volume was given a concentration of 1.0 unit. To reduce the likelihood of numerical instability caused by a discontinuous dye distribution, several rows or columns of mode1 cells were assigned initial concentrations so that the initial distribution gradually decreased from 2.0 to 1.0 unit.

During the simulations, the boundary concentrations of water entering the model domain were specified. The dye concentration of all freshwater entering the model domain was equal to 1.0 unit. At the Gulf of Mexico open boundary when water was leaving the model domain, the model stored the concentrations of the exiting water at each grid cell. The concentrations for up to 60 minutes of simulation time were stored, and concentrations of water that exited more than 60 minutes prior to the current simulation time were discarded. When water was entering the model domain from the gulf, the concentration of the incoming water was determined by reversing the order of 
the stored concentrations at each grid cell. After all the stored concentrations re-entered the model domain, a concentration of 1.0 unit was assumed at the inflow open boundary. This approach approximately returns water to the model domain for the first 60 minutes of a floodtide with the same concentration it had when it left the model domain during the preceeding ebbtide. After 60 minutes, original gulf water was added to the model domain at the open boundary.

The results from each of the four subareas that were injected with dye are presented separately (figs. 31 - 34). These include percentages of initially injected dye that remain in each subarea and Matlacha Pass reported in 15-day increments at mid-tide conditions. Each time increment shows three bars representing the simulated conditions of reduced freshwater inflow, typical freshwater inflow, and typical freshwater inflow without the Sanibel Causeway.

\section{Baseline Simulation}

The simulation of dye injection in upper Charlotte Harbor for typical freshwater inflow (fig. 31) showed that after 15 days 57 percent of the initially injected dye remained in the upper harbor (fig. 31A). The seaward residual flow along the shoreline moved the dye from the upper harbor into lower Charlotte Harbor (fig. 31B) and about half of the mass had reached the lower harbor by the midpoint of the simulation. The concentration of dye in the lower harbor decreased during the second half of the simulation because more dye exited to the Gulf of Mexico and Pine Island Sound (fig. 31C) than entered from the upper harbor. None of the dye injected in the upper harbor entered San Carlos Bay (fig. 31D) during the simulation. Less than 0.5 percent of the injected dye mass entered the northern part of Matlacha Pass (fig. 31E) from the lower harbor. Dye entered the Gulf of Mexico (fig. 31F) through Boca Grande Pass. After 60 days, 16 percent of the injected dye mass remained in upper Charlotte Harbor, 26 percent was in the lower harbor, 2 percent was in Pine Island Sound, and the remainder was in the other subareas in negligible amounts, or had exited the model domain.

For typical freshwater inflow, about one-half of the dye injected into lower Charlotte Harbor left the lower harbor (fig. 32B) after about 15 days. The landward residual flow in the center of Charlotte Harbor transported dye from the lower harbor into the upper harbor (fig. 32A) where the dye concentration peaked at about the midpoint of the simulation. Dye also entered Pine Island Sound (fig. 32C) and the gulf (fig. 32F) through Boca Grande Pass. A small mass of dye, equal to less than 0.5 percent of the total, was initially injected at the northern boundary of Matlacha Pass (fig. $32 E)$ to avoid model instability. The northerly residual flow in the pass transported this dye into the lower Charlotte Harbor.

After 30 days of simulation time, 23 percent of the injected dye mass remained in the lower harbor, 20 percent was in the upper harbor, 4 percent was in the Gulf of Mexico, 2 percent was in Pine Island Sound, and the remaining 51 percent had exited the model domain at the open gulf boundary. Thus, simulation of flushing characteristics for typical freshwater inflow indicates that 30 days after the injection of dye in the lower harbor, the amount of dye that has moved seaward is two and one-half times greater than the amount of dye that has moved landward. The dye concentration decreased in all subareas during the second half of the simulation. After 60 days of simulation time, 15 percent of the injected dye remained in the lower harbor, 15 percent was in the upper harbor, and the remainder of the dye had either 
left the model domain or was in other subareas in negligible amounts. Because 15 percent of the dye mass that was injected in the lower harbor was still present in the upper harbor after 60 days, the model results indicate that landward residual flow in the center of Charlotte Harbor is a significant transport mechanism.

The results of simulated dye injection into Pine Island Sound for typical freshwater inflow (fig. 33C) show that only 36 percent of the dye remained in the sound after 15 days. The dye exited the sound into lower Charlotte Harbor (fig. 33B) and into the Gulf of Mexico (fig. 33F). The dye that entered the lower harbor was located near Boca Grande Pass, through which dye entered the gulf, similar to the movement of particle 70 (fig. 24A). After 15 days, 42 percent of the dye injected into Pine Island Sound was in the gulf, 3 percent was in the lower harbor (fig. 33B), and the remaining 19 percent had exited the model domain. For the simulation of flushing characteristics during typical freshwater inflow, none of the dye injected into Pine Island Sound ever reached the upper harbor (33A) or Matlacha Pass (33E). Only 8 percent of the injected dye mass remained in the model domain after 60 days of simulation time and most of that was in the Gulf of Mexico subarea (fig. 33F).

Simulation of flushing characteristics for injection of dye in San Carlos Bay for typical freshwater inflow shows that after 15 days only 24 percent of the dye is left in the bay (fig. 34D). The residual flow transported most of the dye into Pine Island Sound (fig. 34C), which is consistent with the tracks of the Lagrangian particles that were injected in San Carlos Bay and at the mouth of the Caloosahatchee River. Some dye also moved into Matlacha Pass (fig. 34E) and into the Gulf of Mexico (fig. 34F) through San Carlos Pass. After 15 days, 48 percent of the dye injected into San Carlos Bay was in Pine Island Sound, 4 percent was in the gulf, 3 percent was in Matlacha Pass, and the remainder had exited the model domain. The relatively high percentage of dye in Pine Island Sound indicates that the residual flow from San Carlos Bay into the sound is a significant transport mechanism and that residual transport from the bay into Matlacha Pass and the gulf is relatively minor. Some dye entered lower Charlotte Harbor (fig. 34B) late in the simulation, but no dye reached the upper harbor (fig. 34A). After 60 days of simulation time, 34 percent of the excess dye remained in the model domain, about onethird of which was in Pine Island Sound and the remainder in the gulf.

\section{Reduced Freshwater Inflow Simulation}

Dye injected into upper Charlotte Harbor during simulated reduced freshwater inflow remained in the harbor for a longer period of time than with the simulation of typical freshwater inflow (fig. 31A). After 15 days, 65 percent of the injected dye mass remained in the upper harbor for reduced freshwater inflow compared to 57 percent for typical freshwater inflow. Almost 30 days were needed to flush one-half of the injected dye from the upper harbor for reduced freshwater inflow compared to a little more than 15 days for typical freshwater inflow. This increase in residence time is consistent with the increased residence times and decreased seaward residual velocities for reduced freshwater inflow that were determined with Lagrangian particles. Thus, reduced freshwater inflow decreases the flushing of the upper harbor. Lower Charlotte Harbor receives seaward residual flow from the upper harbor. Therefore, the arrival of dye in the lower harbor during this simulation was slower, but extended over a longer period of time (fig. 31B). The arrival of dye in Pine Island Sound (fig. 31C) was delayed by the reduced seaward residual transport in Charlotte Harbor. Less than 0.5 percent of the 
injected dye mass entered the northern part of Matlacha Pass during the simulation for reduced freshwater inflow (fig. 31E). None of the dye injected in the upper harbor for reduced freshwater inflow arrived in San Carlos Bay (fig. 31D) or could be detected in the Gulf of Mexico (fig. 31F).

The simulated injection of dye in lower Charlotte Harbor (fig. 32) indicated that the flushing time of the lower harbor (fig. 32B) was reduced only slightly by the reduction in freshwater inflow and that the net landward residual transport into upper Charlotte Harbor increased (fig. 32A). Slightly more dye remained in the lower harbor for reduced freshwater inflow than remained for typical freshwater inflow (fig. 32B). The time required to flush one-half of the injected dye mass from the lower harbor was not significantly different for typical and reduced freshwater inflows (about 15 days). Because the river flow was smaller, the seaward residual flow in the upper harbor was reduced and more dye mass accumulated in the upper harbor. For example, after 30 days, 20 percent of the excess dye injected in the lower harbor had moved landward into the upper harbor for typical freshwater inflow, but 24 percent of the excess injected dye had moved into the upper harbor for reduced freshwater inflow. Thus, reduced freshwater inflow significantly reduces the seaward residual transport, and the result is a net increase in landward residual transport. The concentration of dye in the Gulf of Mexico (fig. 32F) decreased more slowly for reduced freshwater inflow than it did for typical freshwater inflow because dye entered the gulf more slowly from Charlotte Harbor. The concentration of dye in Pine Island Sound (fig. 32C) was slightly greater for reduced freshwater inflow, although the amount of excess dye mass in the sound was relatively small. In San Carlos Bay (fig. 32D) and Matlacha Pass (fig. 32E) the flushing characteristics for dye injected in lower Charlotte Harbor were the same for reduced freshwater inflow as for typical freshwater inflow.

The flushing time of dye injected into Pine Island Sound was increased only slightly by the simulated reduction in freshwater inflow. The excess concentration of dye in the sound was slightly greater for reduced freshwater inflow than it was for typical freshwater inflow (fig. 33C). The time required to flush one-half of the injected dye mass from the sound was not significantly different for typical and reduced freshwater inflows (less than 15 days). Because dye remained in the sound longer, the dye concentration in the Gulf of Mexico (fig. 33F) was slightly reduced. Slightly more dye mass moved into lower Charlotte Harbor (fig. 33B) for the reduced freshwater inflow simulation, but concentrations of dye in the other subareas did not change significantly (fig. 33A, 33D, and 33E).

The simulated reduction in freshwater inflow slightly altered the residual transport from $S$ an Carlos Bay. The reduction in freshwater inflow slightly increased the flushing time of San Carlos Bay as dye remained in the bay longer (fig. 34D). The time required to flush one-half of the injected dye mass from the bay was not significantly different for typical and reduced freshwater inflows (less than 15 days). The injected dye moved into Pine Island Sound more slowly (fig. 34C), and was flushed from the sound over a longer period of time, as indicated by the slightly lower percentage for days 15 and 30 and the higher percentage for days 45 and 60 . Because the dye is released more slowly from San Carlos Bay and Pine Island Sound with reduced freshwater inflow, the concentration of dye in the Gulf of Mexico (fig. 34F) is reduced. The greater concentration of dye in Matlacha Pass indicates that the residual transport from San Carlos Bay to Matlacha Pass (fig. 34E) increases with reduced freshwater inflow. This is consistent with the 
increased displacement of particle 134 (fig. 23) for reduced freshwater inflow. The movement of dye injected in San Carlos Bay to the lower (fig. 34B) and upper harbor (fig. 34A) was about the same for reduced freshwater inflow as for typical freshwater inflow.

\section{Simulation Without Sanibel Causeway}

Removal of the Sanibel Causeway did not significantly affect the results of the injection of dye in upper Charlotte Harbor for the typical freshwater inflow simulation. Percentage of dye in the upper harbor ( $f i g .31 \mathrm{~A}$ ) was unaffected by removal of the causeway, and percentages of dye in the other subareas (figs. 31B, 31C, 31D, 31E, 31F) were either unchanged or only slightly altered.

Results of the injection of dye in lower Charlotte Harbor (figs. 32A-32F) were not significantly altered by removing the causeway. Percentages of dye in most subareas at most times were virtually the same with or without the causeway.

Results of the injection of dye in Pine Island Sound (figs. 33A-33F) indicate that removal of the Sanibel Causeway did not significantly affect flushing in the sound. The time required to flush one-half of the excess injected dye mass did not change from the value of about 11 days with the causeway in place. For dye injection in Pine Island Sound with the causeway removed, changes in flushing characteristics in the other subareas were also insignificant.

Removal of the causeway slightly increased the residual flow from San Carlos Bay into Pine Island Sound ( $\mathrm{fig}$. 34C) and slightly decreased the residual flow from the bay into Matlacha Pass (fig. 34E). The dye injected in San Carlos Bay remained in the bay (fig. 34D) slightly longer when the causeway was removed. However, the time required to flush one-half of the excess injected dye mass did not significantly change from the value of about 9 days with the causeway in place. The percentage of dye in Pine Island Sound (fig. 34C) was slightly increased by removing the causeway, and the percentage of dye in Matlacha Pass was slightly decreased (fig. 34E). Near the end of the simulation there was a slight increase in the percentage of dye in the lower harbor (fig. 34B) and a larger increase in the Gulf of Mexico (fig. $34 \mathrm{~F}$ ). The upper harbor (fig. 34A) showed no change.

\section{SUMMARY}

Charlotte Harbor is a coastal plain estuarine system on the west coast of Florida that is being subjected to increased environmental stress by rapid population growth and development. To evaluate the probable response of the estuarine system to growth-induced changes, a hydrodynamic model was developed to define the characteristics of the estuarine system and its interaction with the inflowing river systems and the Gulf of Mexico.

A two-dimensional circulation and constituent-transport model, SIMSYS2D, was used to simulate water motion and transport in Charlotte Harbor. The model was driven by tidal stage at the seaward boundary in the Gulf of Mexico and included freshwater inflows from the Myakka, Peace, and Caloosahatchee Rivers. The model was calibrated and verified using field observations of tidal stage at eight sites, tidal discharge at five major inlets, and tidal velocity and direction at nine sites. The calibration and verification 
periods included spring and neap tide ranges, respectively. Standard errors of simulated tidal stage for the calibration and verification periods averaged about $0.1 \mathrm{ft}$, which represents an average of about 3 percent of the stage range at the measurement sites. Standard errors of simulated discharge through the tidal inlets ranged from 3 to 10 percent of the range of flow measured in the inlets for the calibration period.

Application of the model is limited to conditions that can be depth averaged, which excludes density stratification of the water column. Depth-averaged baroclinic terms were included in the model, but the model cannot reproduce the bottom landward residual flow and the seaward surface residual flow that may be present if these terms are significant. Model simulations were performed without wind forcing, so wind-induced residual circulation was not considered.

Following calibration and verification, the model was used to simulate hydrodynamic and constituent transport for three different conditions. The first simulation represented the existing physical configuration of the estuarine system, typical tidal patterns, and typical freshwater inflow from the three major tributaries. The same physical configuration and tidal patterns were used for the second simulation, but freshwater inflow from the tributaries was substantially reduced. The third simulation used the same tidal patterns and freshwater inflow as the first simulation, but the model configuration was altered to represent physical conditions that might exist if the Sanibel Causeway was removed.

Residual circulation patterns for the three simulations were evaluated through Lagrangian particle tracks. For the current physical configuration, the residual flow patterns were similar for both typical and reduced freshwater inflow. Residual flow from the Myakka River moves southward along the western shore of upper Charlotte Harbor. Residual flow from the Peace River moves southward along either the western or eastern shore of the upper harbor. Both upper and lower Charlotte Harbor have a seaward residual flow along the shoreline and a landward residual flow in the deep center channel. This residual flow pattern can be generated by floodtide flow that follows the deep channel from Boca Grande Pass through the lower harbor and may be enhanced by inertia and friction. A residual stagnation point was observed in upper Charlotte Harbor for the typical freshwater inflow simulation but was not apparent in the particle tracks when freshwater inflow was reduced. The residual flow in Gasparilla Sound is toward Gasparilla Pass. Most of the residual flow that enters San Carlos Bay from the Caloosahatchee River moves into Pine Island Sound, but some moves north into Matlacha Pass and some moves south into the Gulf of Mexico. The northerly residual flow in southern Pine Island Sound is stronger in the relatively deeper center channel than it is in the surrounding shallow water. The residual flow in Matlacha Pass is small and northward. The Gulf of Mexico has a southerly residual flow, and water mass that enters the gulf through a northern pass can reenter the estuarine system through an inlet farther south.

A decrease in freshwater inflow reduced the residual flow in some parts of the estuary. The residence time in the upper harbor of water from the Myakka River was about five times greater for reduced freshwater inflow than it was for typical freshwater inflow, and the residence time of water from the Peace River was about two times greater for reduced freshwater inflow. The residence time in San Carlos Bay also increased when freshwater inflow was decreased. An exception was the nearly northward residual velocity in Matlacha Pass. The residual flow in Matlacha Pass seemed to be a combination 
of a southerly riverine flow that is dependent upon the freshwater inflow and a northerly tidal component that is dependent upon the spring-neap cycle. Residual flow in Gasparilla Sound, Pine Island Sound, and the Gulf of Mexico was not significantly affected by the difference in freshwater inflow.

The particle tracks do not conclusively indicate the effect of removing the Sanibel Causeway on the northerly residual flow in Pine Island Sound. Causeway removal did not significantly affect residual flows in Matlacha Pass, Gasparilla Sound, the Gulf of Mexico, or the upper and lower Charlotte Harbor.

In addition to Lagrangian particles, injections of dye were simulated to analyze the flushing characteristics of the estuary. For each of the three 65-day simulations, dye was injected into one of four subareas of Charlotte Harbor. Results of the dye injections confirm the residual circulation patterns observed with the Lagrangian particles and provide quantitative information on the flushing times.

For the simulation of typical freshwater inflow, after 15 days, 57 percent of the dye injected into upper Charlotte Harbor remained in the upper harbor, 48 percent of the dye injected in the lower harbor remained in the lower harbor, 36 percent of the dye injected into Pine Island Sound remained in the sound, and 24 percent of the dye injected into San Carlos Bay remained in the bay. The upper harbor has a relatively long flushing time, probably because it is not directly connected to the gulf and some of the dye that exits to the lower harbor returns to the upper harbor by way of the landward residual flow in the deep center channel. The lower harbor has a substantial tidal exchange with the Gulf of Mexico through Boca Grande Pass, which provides flushing, but the landward residual flow into the upper harbor retards flushing. Most of the dye injected into Pine Island Sound entered the gulf relatively quickly because of the tidal exchange through Captiva and Redfish Passes; residual flow in the sound is seaward. San Carlos Bay has a relatively short residence time, but the residual flow from San Carlos Bay is into Pine Island Sound, not directly into the gulf, so most of the injected dye was landward of the barrier islands for longer than 15 days.

Mode1 simulation of reduced freshwater inflow indicated that the residence times in some subareas increased as the freshwater inflow decreased. Dye injected in upper Charlotte Harbor remained in the harbor longer with reduced freshwater inflow than with typical freshwater inflow. After 15 days, 65 percent of the excess injected dye mass remained in the upper harbor for reduced freshwater inflow compared to 57 percent for typical freshwater inflow. Reduced freshwater inflow significantly reduced the seaward residual transport from the upper to the lower harbor, and the result was a net increase in landward residual transport. The flushing time of Pine Island Sound was reduced only slightly by the simulated reduction in freshwater inflow. Reduced freshwater inflow slightly decreased the residual transport from San Carlos Bay to Pine Island Sound and slightly increased the residual transport from the bay to Matlacha Pass.

The simulated injection of dye indicated that removal of the Sanibel Causeway slightly affected flushing of the southern study area. Residual flow from San Carlos Bay into Pine Island Sound was increased, and residual flow from the bay into Matlacha Pass was decreased. Upper and lower Charlotte Harbor were not affected by removal of the causeway. Residual circulation was affected more by the simulated difference in freshwater inflow than by the simulated removal of the causeway. 


\section{REFERENCES}

Boggess, D.H., 1970, The magnitude and extent of salt-water contamination in the Caloosahatchee River between La Belle and 01ga, Florida: Florida Bureau of Geology Information Circular no. 62, pt. 2, p. 17-39.

Cheng, R.T., and Casulli, Vincenzo, 1982, On Lagrangian residual currents with applications in south San Francisco Bay, California: Water Resources Research, v. 18, no. 6, p. 1652-1662.

Eckert, C., 1958, The equation of state of water and sea water at low termperatures and pressures: American Journal of Science, v. 256, p. $240-250$.

Elder, J.W., 1959, The dispersion of marked fluid in turbulent shear flow: Journal of Fluid Mechanics, v. 5, p. 544-560.

Estevez, E.D., 1986, Infaunal macroinvertebrates of the Charlotte Harbor estuarine system and surrounding inshore waters, Florida: U.S. Geological Survey Water-Resources Investigations Report 85-4260, 116 p.

Filadelfo, Ronald, Wilson, R.E., and Gomez-Reyes, Eugenio, 1991, Subtidal Eulerian currents in the upper and lower East River tidal strait: Spring 1981: Journal of Geophysical Research, v. 96, no. C8, p. 15217-15226

Fischer, H.B., List, E.J., Koh, R.C.Y., Imberger, Jorg, and Brooks, N.H., 1979, Mixing in inland and coastal waters: Orlando, Fla., Academic Press, $483 \mathrm{p}$.

Florida Department of Natural Resources, 1984, Estuaries: St. Petersburg, Fla., Bureau of Marine Research pamphlet.

Fraser, T.H., 1986, Long-term water-quality characteristics of Charlotte Harbor, Florida: U.S. Geological Survey Water-Resources Investigations Report 86-4180, 43 p.

Goodwin, C.R., 1987, Tidal-flow, circulation, and flushing changes caused by dredge and fill in Tampa Bay, Florida: U.S. Geological Survey WaterSupply Paper 2282, 88 p.

-.. 1991a, Tidal-flow, circulation, and flushing changes caused by dredge and fill in Hillsborough Bay, Florida: U.S. Geological Survey Open-File Report 88-76, $85 \mathrm{p}$.

-... 1991b, Simulation of the effects of proposed tide gates on circulation, flushing, and water quality in residential canals, Cape Coral, Florida: U.S. Geological Survey Open-File Report 91-237, 43 p.

Goodwin C.R., and Michaelis, D.M., 1976, Tides in Tampa Bay, Florida: June 1971 to December 1973: U.S. Geological Survey Open-File Report FL-75004, $338 \mathrm{p}$.

Hammett, K.M., 1990, Land use, water use, streamflow characteristics and water-quality characteristics of the Charlotte Harbor inflow area, Florida: U.S. Geological Survey Water-Supply Paper 2359-A, 64 p.

-..- 1992, Physical processes, salinity characteristics, and potential salinity changes due to freshwater withdrawals in the tidal Myakka River, Florida: U.S. Geological Survey Water-Resources Investigations Report $90-4054,20 \mathrm{p}$.

Holley, E.R., 1969, Unified view of diffusion and dispersion: American Society of Civil Engineers, v. 95, no. HY2, p. 621-631.

Hunter, J.R., and Hearn, C.J., 1987, Lateral and vertical variations in the wind-driven circulation in long shallow lakes: Journal of Geophysical Research, v. 92, p. 13106-13114.

Hydrosystems Associates, Inc., 1989, The Sanibel Bridge study: Tampa, Fla., Consultant's report prepared for Lee County, $83 \mathrm{p}$.

Jin, Kang-Ren, and Raney, D.C., 1991, Horizontal salinity gradient effects in Apalachicola Bay: Journal of Waterway, Port, Coastal, and Ocean Engineering, v. 117, no. 5, p. 451-470. 
Leendertse, J.J., 1970, A water-quality simulation mode1 for wel1-mixed estuaries and coastal seas: Volume I, Principles of computation: Santa Monica, Calif., The Rand Corporation, RM-6230-RC, 71 p.

-..- 1987, Aspects of SIMSYS2D, a system for two-dimensional flow computation: Santa Monica, Calif., The Rand Corporation, R-3572-USGS, $80 \mathrm{p}$.

Leendertse, J.J., and Gritton, E.C., 1971, A water-quality simulation mode1 for well-mixed estuaries and coastal seas: Volume II, Computation procedures: New York, The New York City Rand Institute, R-708-NYC, 48 p. McAnally, W.H., Letter, J.V., Stewart, J.P., Thomas, W.A., and Brogdon, N.J., 1984, Application of Columbia Hybrid Modeling System: Journal of Hydraulic Engineering, American Society of Civil Engineering, v. 110, no. 5, p. 627-642.

McPherson, B.F., and Miller, R.L., 1987, The vertical attenuation of light in Charlotte Harbor, a shallow, subtropical estuary, southwestern Florida: Estuarine, Coastal and Shelf Science, v. 25, p. 721-737.

... 1990, Nutrient distribution and variability in the Charlotte Harbor estuarine system, Florida: Water Resources Bulletin, v. 26, no. 1, p. $67-80$.

McPherson, B.F., and Montgomery, R.T., 1989, The effects of freshwater inflow on the phytoplankton carbon-14 productivity and chlorophyll-a in the Charlotte Harbor estuarine system, southwestern Florida: in U.S. Geological Survey Second National Symposium on Water Quality: Abstracts of the Technical Sessions, Orlando F1a., November 12-17, 1989, U.S. Geological Survey Open-File Report 89-409, p. 60.

Miller, R.L., and McPherson, B.F., 1987, Concentration and transport of phosphorus and radium-226 in the Peace River and Charlotte Harbor, southwestern Florida: Proceedings of the American Chemical Society, New Orleans, La., August 30-September 4, 1987, p. 389-391.

-.. 1991, Estimating estuarine flushing and residence times in Charlotte Harbor, Florida, via salt balance and a box model: Limnology and Oceanography, v. 36, no. 3, p. 602-612.

Pritchard, D.W., and Vieira, M.E.C., 1984, Vertical variation in residual current response to meteorological forcing in the mid-Chesapeake Bay, in Kennedy, V.S., ed., The estuary as a filter: New York, Academic Press, p. $27-65$.

Ridderinkhof, H., and Zimmerman, J.T.F., 1990, Mixing processes in a numerical model of the western Dutch Wadden Sea, in Cheng, R.T., ed., Residual currents and long-term transport: New York, Springer-Verlag, v. 38, p. 194-209.

Scarlatos, P.D., 1988, Caloosahatchee Estuary hydrodynamics: South Florida Water Management District Technical Publication 88-7, 39 p.

Schoellhamer, D.H., and Jobson, H.E., 1986, User's manual for a onedimensional Lagrangian transport mode1: U.S. Geological Survey WaterResources Investigations Report 86-4145, 95 p.

Sheng, Y.P., Parker, S.F., and Henn, D.S., 1985, A three-dimensional estuarine hydrodynamic software mode1: Princeton, N.J., Aeronautical Research Associates of Princeton Report no. 568, 125 p.

Smith, L.H., and Cheng, R.T., 1987, Tidal and tidally averaged circulation characteristics of Suisun Bay, California: Water Resources Research, v. 23, no. 1, p. 143-155.

Smith, P.E., Cheng, R.T., Burau, J.R., and Simpson, M.R., 1991, Gravitationa1 circulation in a tidal strait: Proceedings, National Conference on Hydraulic Engineering, July 29-August 2, 1991, Nashville, Tenn., p. 429-434. 
Southwest Florida Water Management District, 1988, A citizen's guide to the SWIM priority 1ist: Surface Water Improvement and Management Report, $23 \mathrm{p}$.

Stoker, Y.E., 1986, Water-quality of the Charlotte Harbor estuarine system, Florida, November 1982 through October 1984: U.S. Geological Survey Open-File Report 85-563, 213 p.

.... 1992, Salinity distribution, and variation with freshwater inflow and tide, and potential changes in salinity due to altered freshwater inflow in the Charlotte Harbor estuarine system, Florida: U.S. Geological Survey Water-Resources Investigations Report 92-4062, $30 \mathrm{p}$.

Stoker, Y.E., Henderson, S.E., and McPherson, B.F., 1989, Hydraulic and salinity characteristics of the tidal reach of the Peace River, southwestern Florida: U.S. Geological Survey Water-Resources Investigations Report 88-4162, $37 \mathrm{p}$.

Stoker, Y.E., and Karavitis, G.A., 1983, Literature assessment of the Charlotte Harbor estuarine system and surrounding area, southwest Florida: U.S. Geological Survey Open-File Report 83-127, 144 p.

Stomme1, H., and Farmer, H.G., 1952, On the nature of estuarine circulation: Woods Hole Oceanographic Institute References Nos. 52-51, 52-63, 52-88 ( $3 \mathrm{v}$. containing chap. 1-4 and 7).

U.S. Geological Survey, 1986, Water resources data for Florida, v. 3A, southwest Florida surface water: published annually.

U.S. National Oceanic and Atmospheric Administration, 1981, Estero Bay to Lemon Bay, including Charlotte Harbor: Asheville, N.C., National Ocean Service, Nautical Chart 11426, 1 sheet.

-... 1985a, Tidal current tables 1985-Atlantic Coast of North America: Asheville, N.C., National Ocean Service, 241 p.

... 1985b, Tide tables 1985-High and low water predictions-east coast of North and South America including Greenland: Asheville, N.C., National Ocean Service, $258 \mathrm{p}$. 
Illustrations 


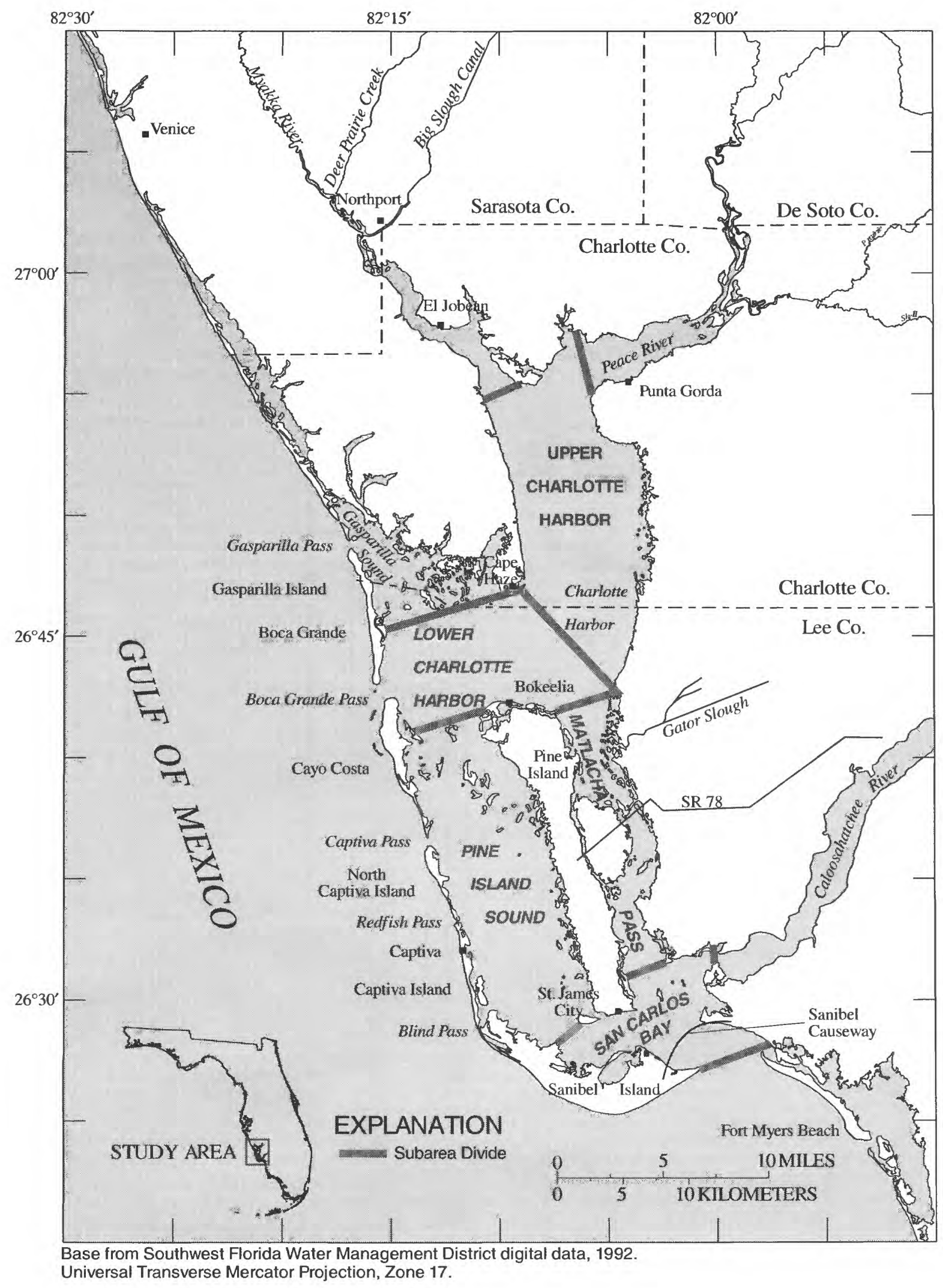

Figure 1. Charlotte Harbor estuarine system and subareas. 


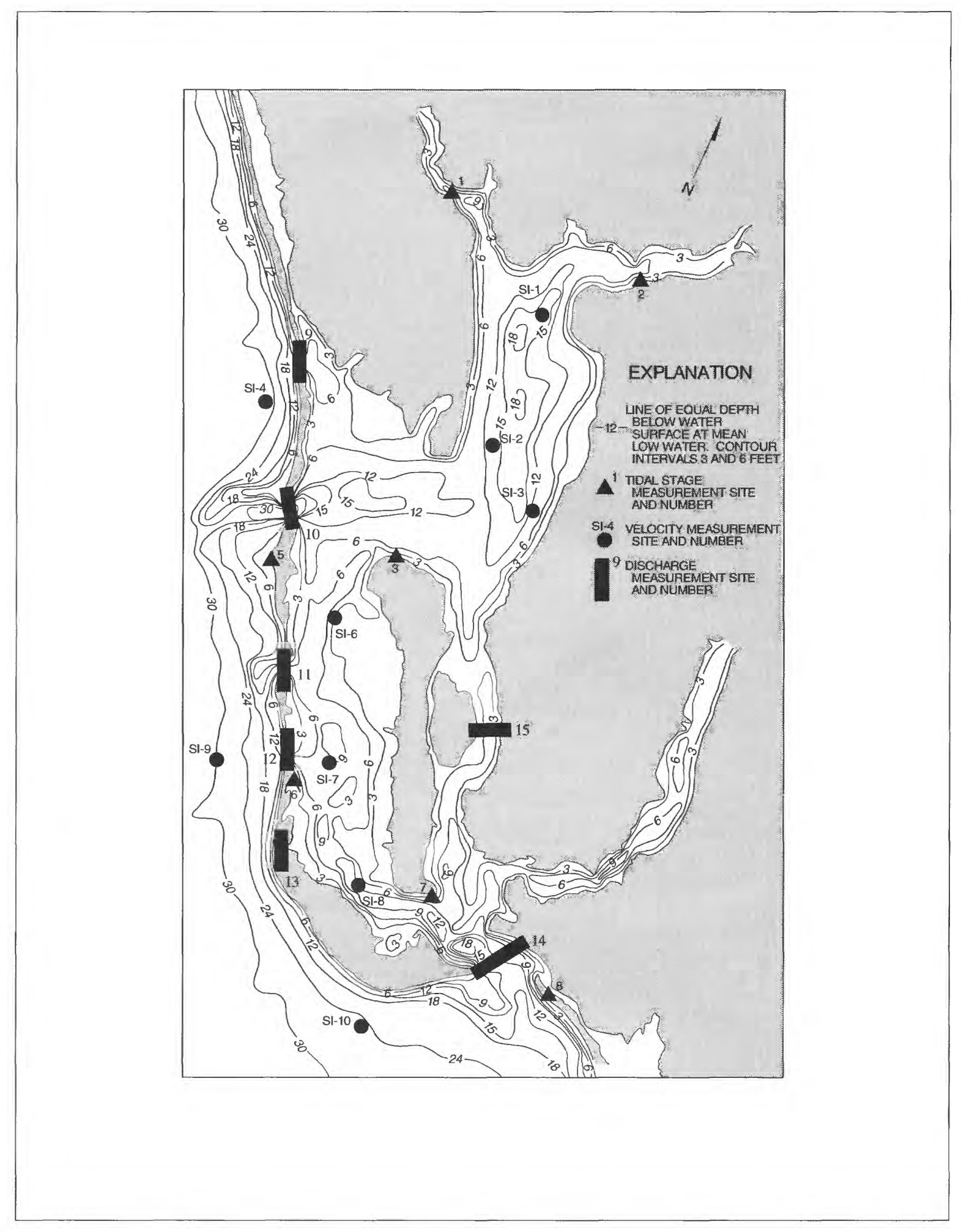

Figure 2. Generalized bottom configuration of Charlotte Harbor estuarine system and nearshore Gulf of Mexico, and data-measurement sites. 

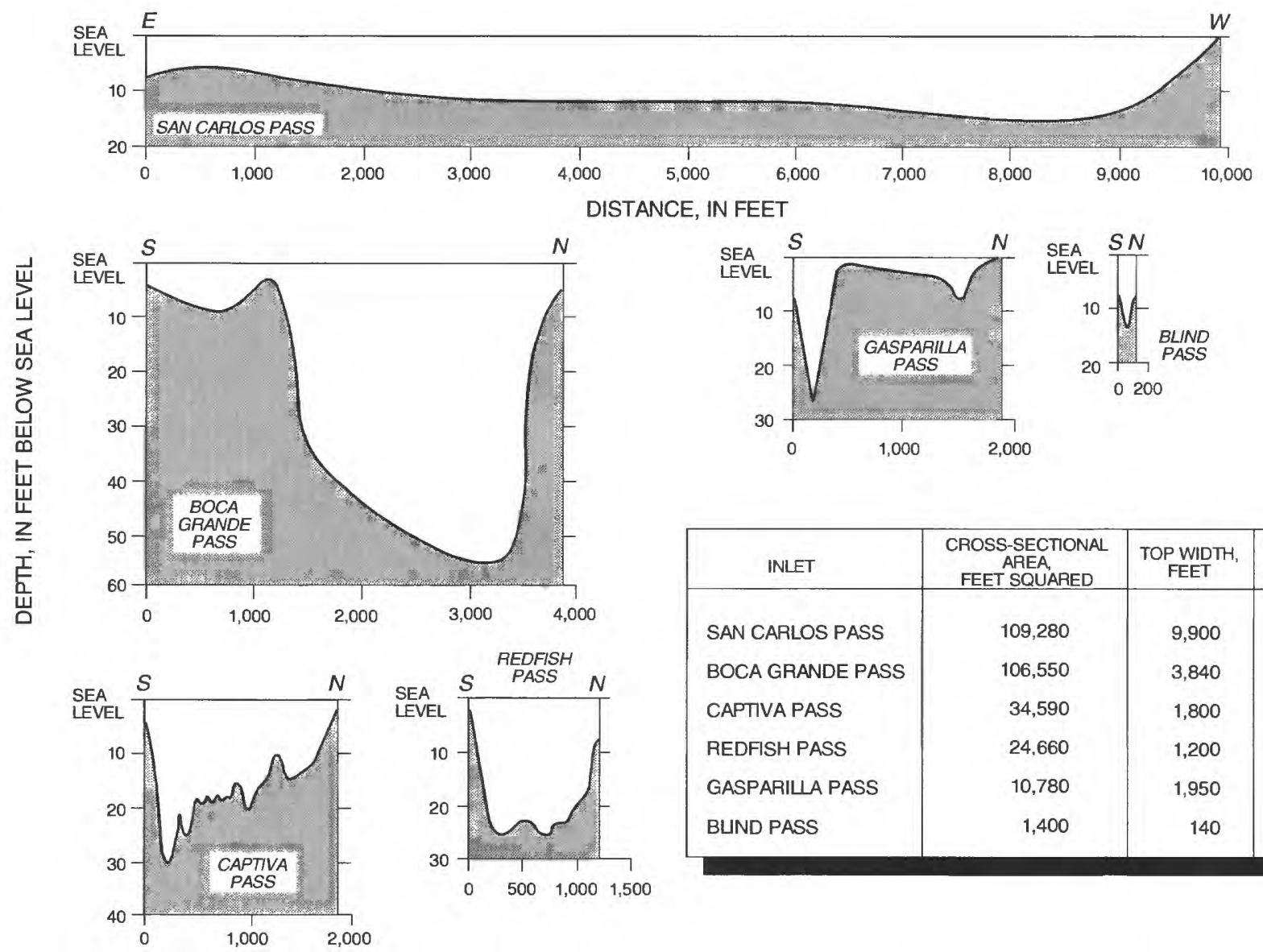

\begin{tabular}{|l|c|r|r|}
\hline \multicolumn{1}{|c|}{ INLET } & $\begin{array}{c}\text { CROSS-SECTONAL } \\
\text { AREA } \\
\text { FEET SQUARED }\end{array}$ & $\begin{array}{c}\text { TOP WIDTH, } \\
\text { FEET }\end{array}$ & $\begin{array}{c}\text { MAXIMUM } \\
\text { DEPTH. } \\
\text { FEET }\end{array}$ \\
\hline SAN CARLOS PASS & 109,280 & 9,900 & 16 \\
BOCA GRANDE PASS & 106,550 & 3,840 & 55 \\
CAPTIVA PASS & 34,590 & 1,800 & 31 \\
REDFISH PASS & 24,660 & 1,200 & 27 \\
GASPARILA PASS & 10,780 & 1,950 & 26 \\
BUND PASS & 1,400 & 140 & 14 \\
\hline
\end{tabular}

Figure 3. Cross sections of tidal inlets. 

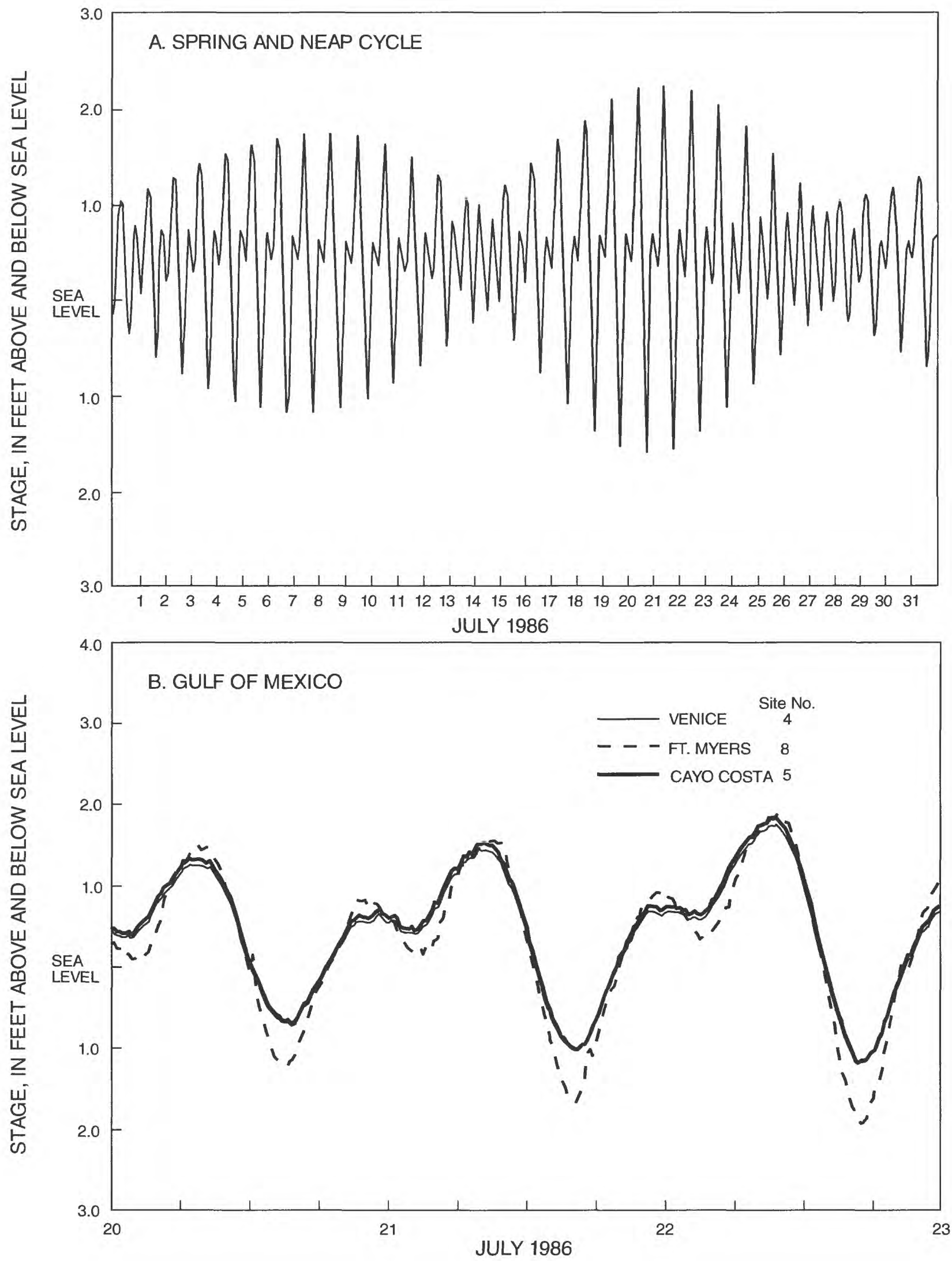

Figure 4. Typical monthly spring and neap tidal cycle in: (a) the Gulf of Mexico and comparative daily tides for (b) the Gulf of Mexico, (c) northern Charlotte Harbor, and (d) southern Charlotte Harbor. 

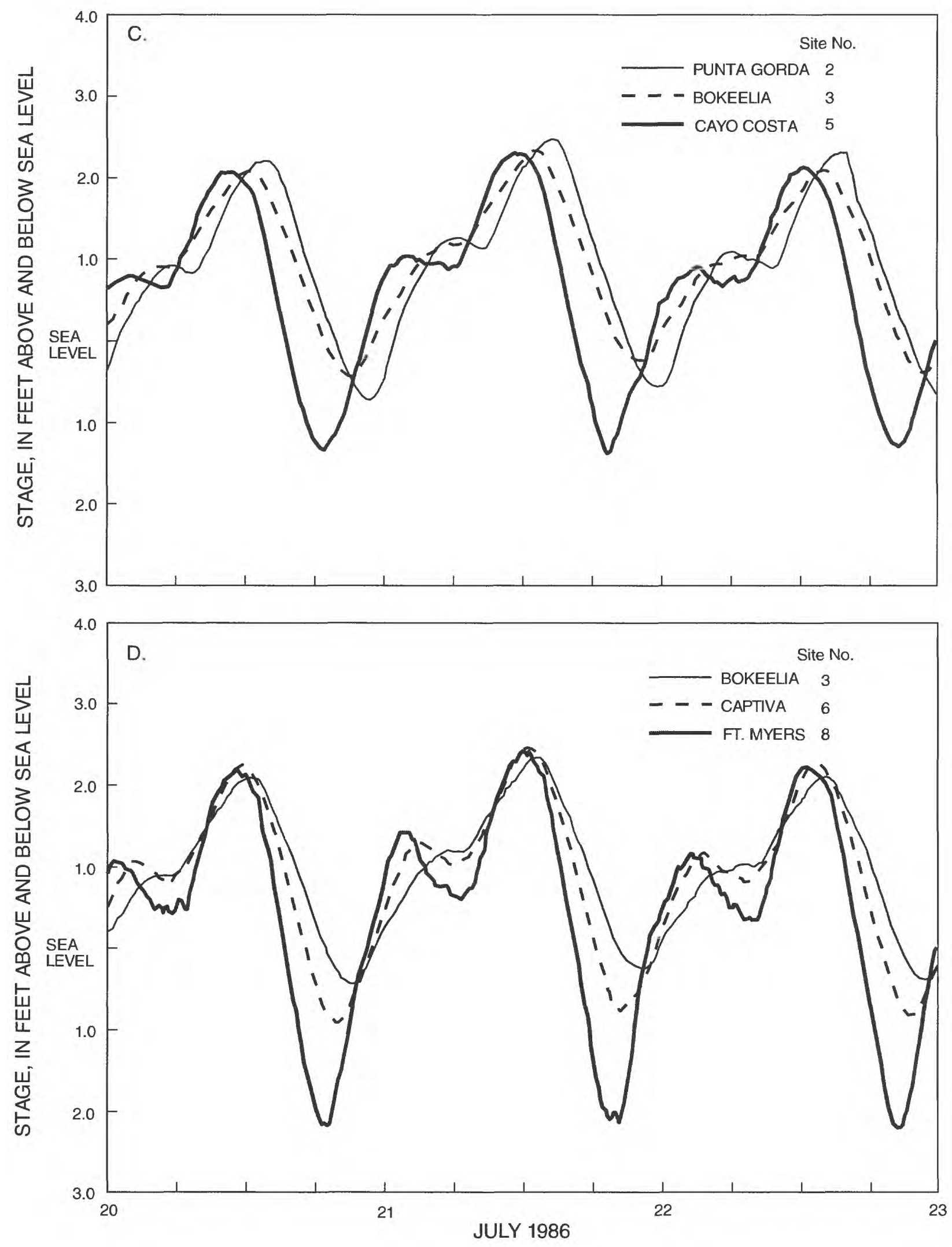

Figure 4. Continued.-- Typical monthly spring and neap tidal cycle in: (a) the Gulf of Mexico and comparative daily tides for (b) the Gulf of Mexico, (c) northern Charlotte Harbor, and (d) southern Charlotte Harbor. 


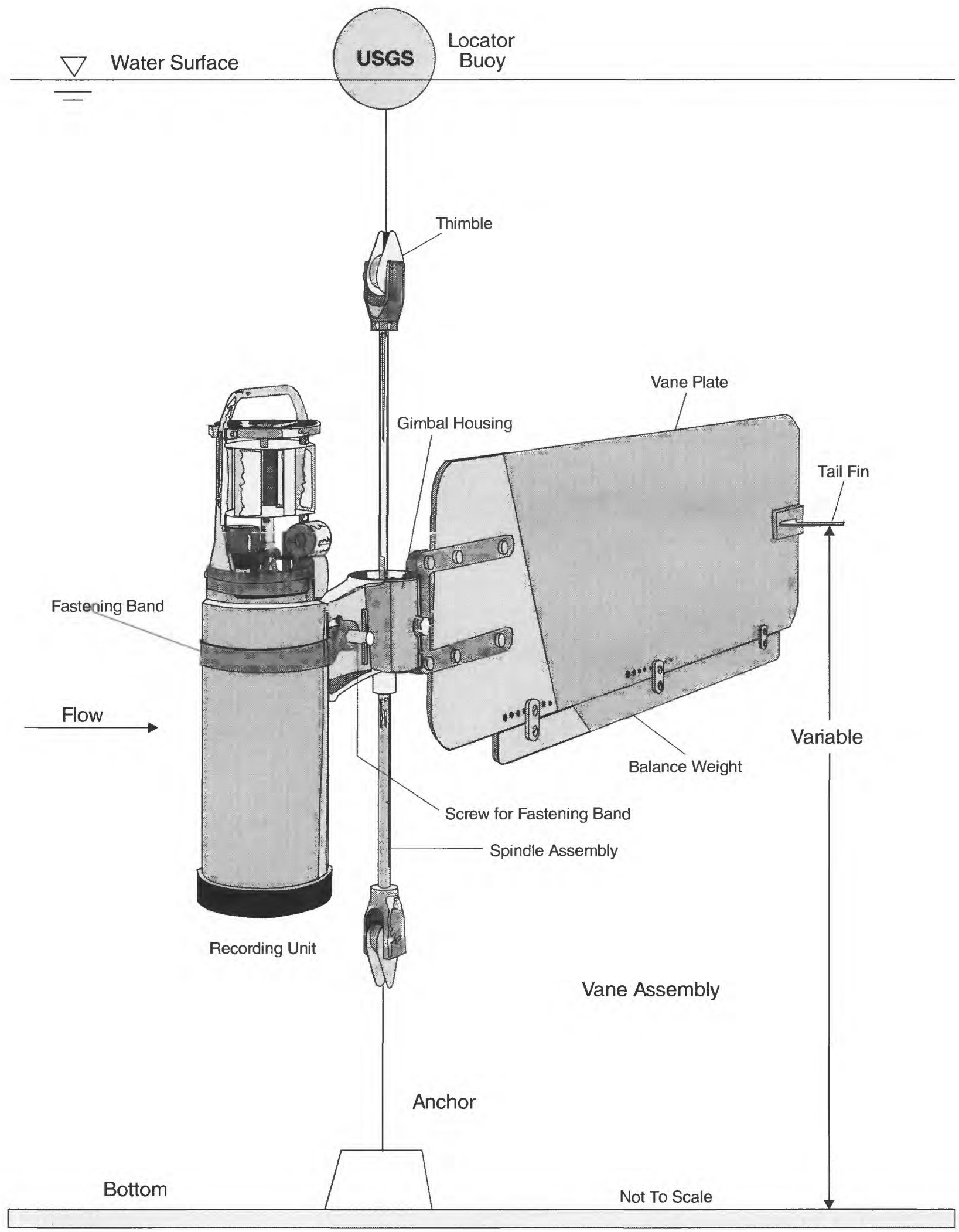

Figure 5. Typical deployment of tidal velocity current meter. 


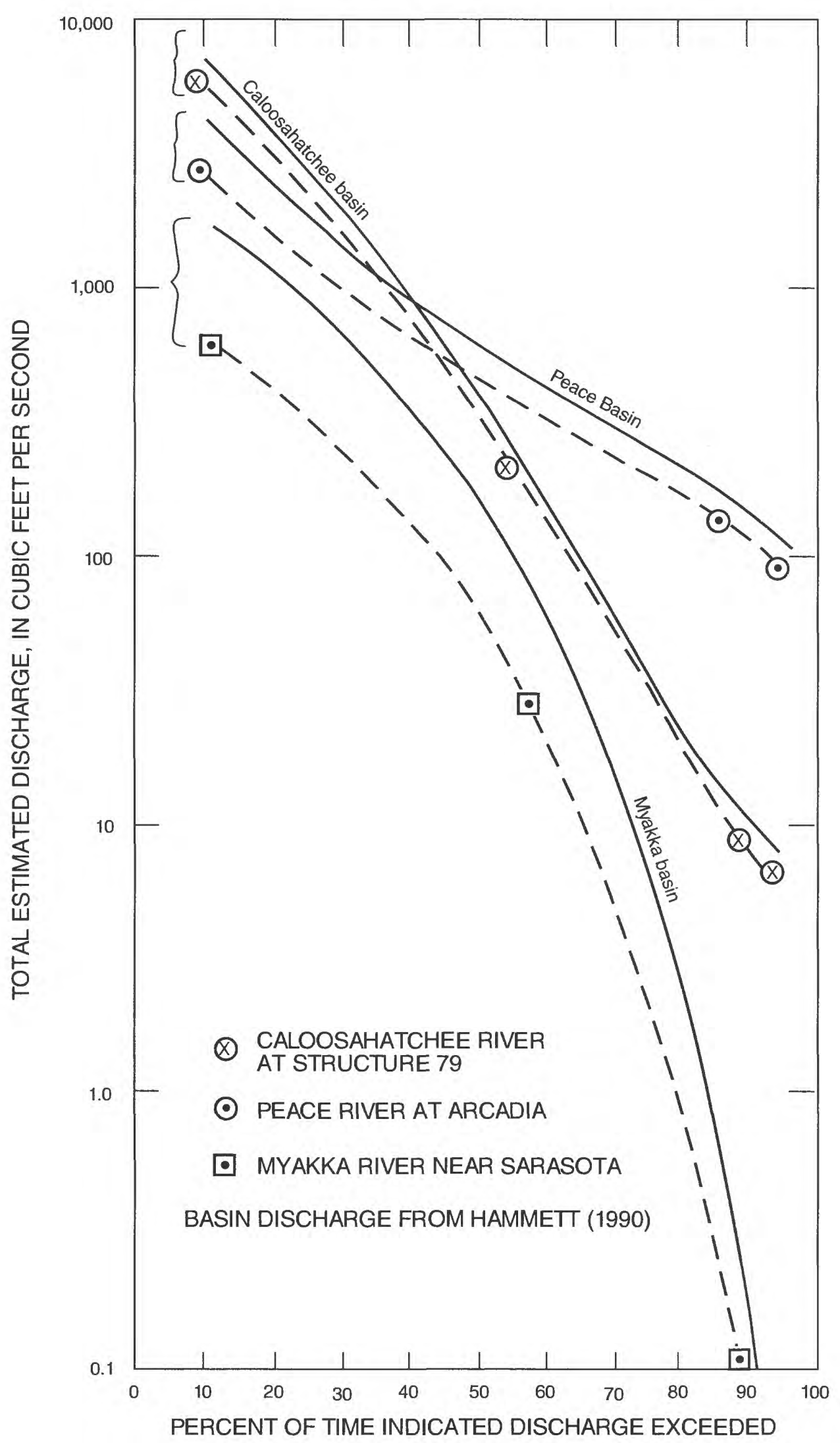

Figure 6. Streamflow duration curves for the Myakka, Peace, and Caloosahatchee River basins. 


\section{HIGHLY STRATIFIED}

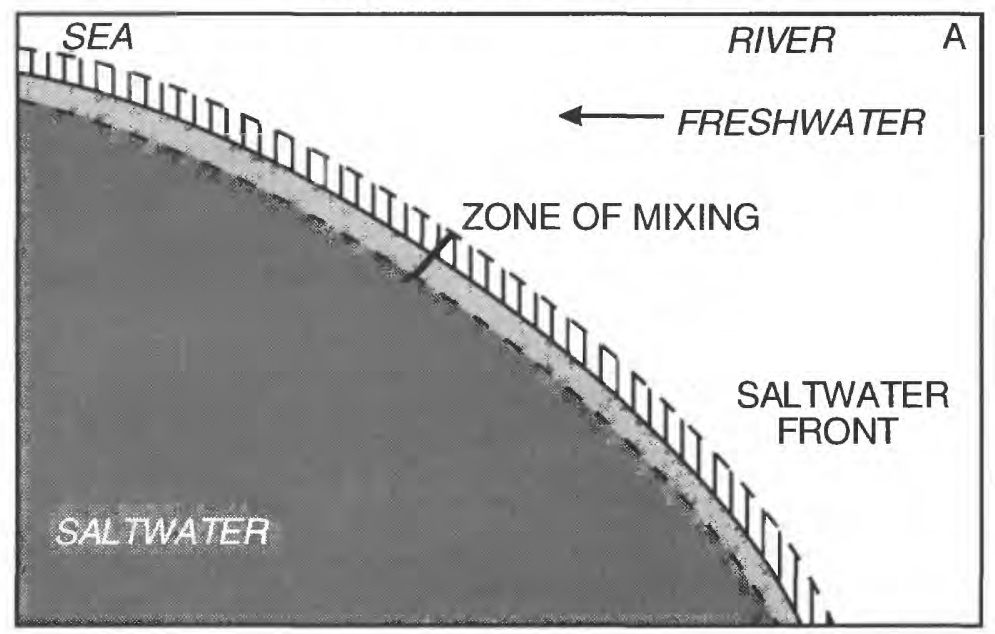

PARTIALYY MIXED

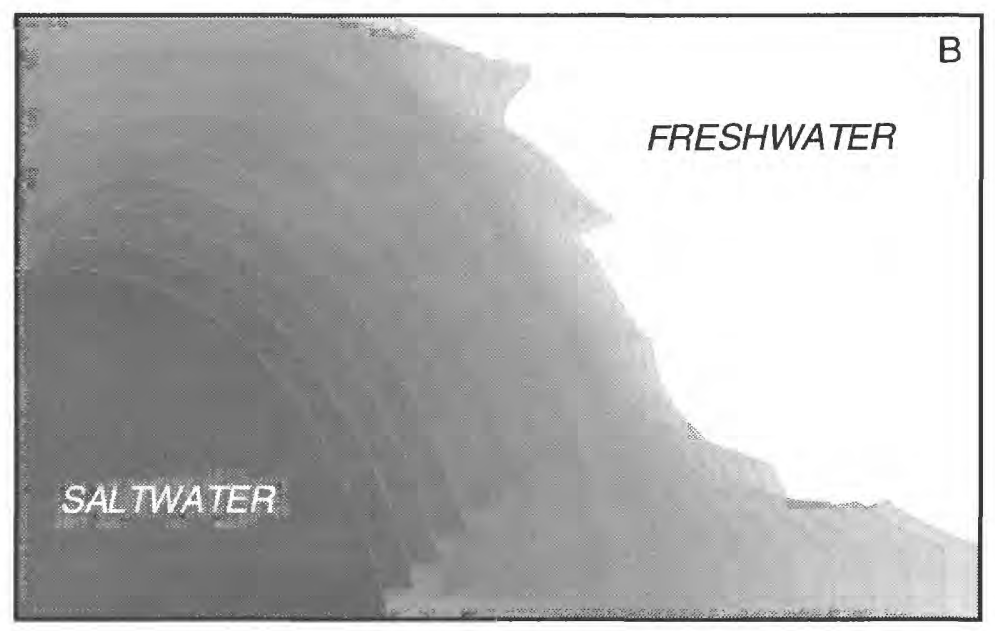

WELL MIXED

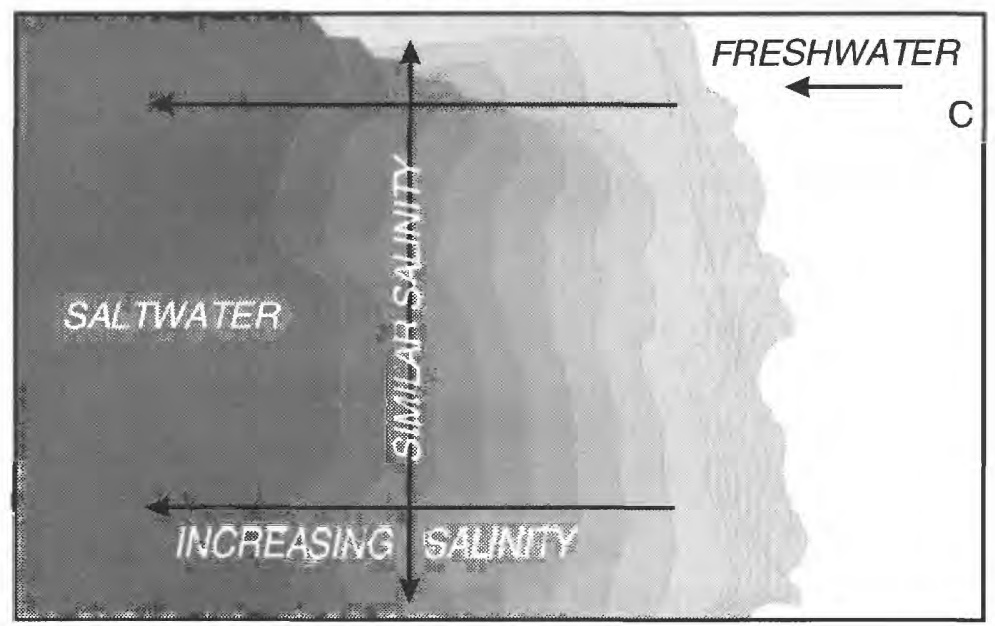

Figure 7. Highly-stratified, partially-mixed, and wellmixed vertical distributions of salinity. (From Hammett, 1992.) 


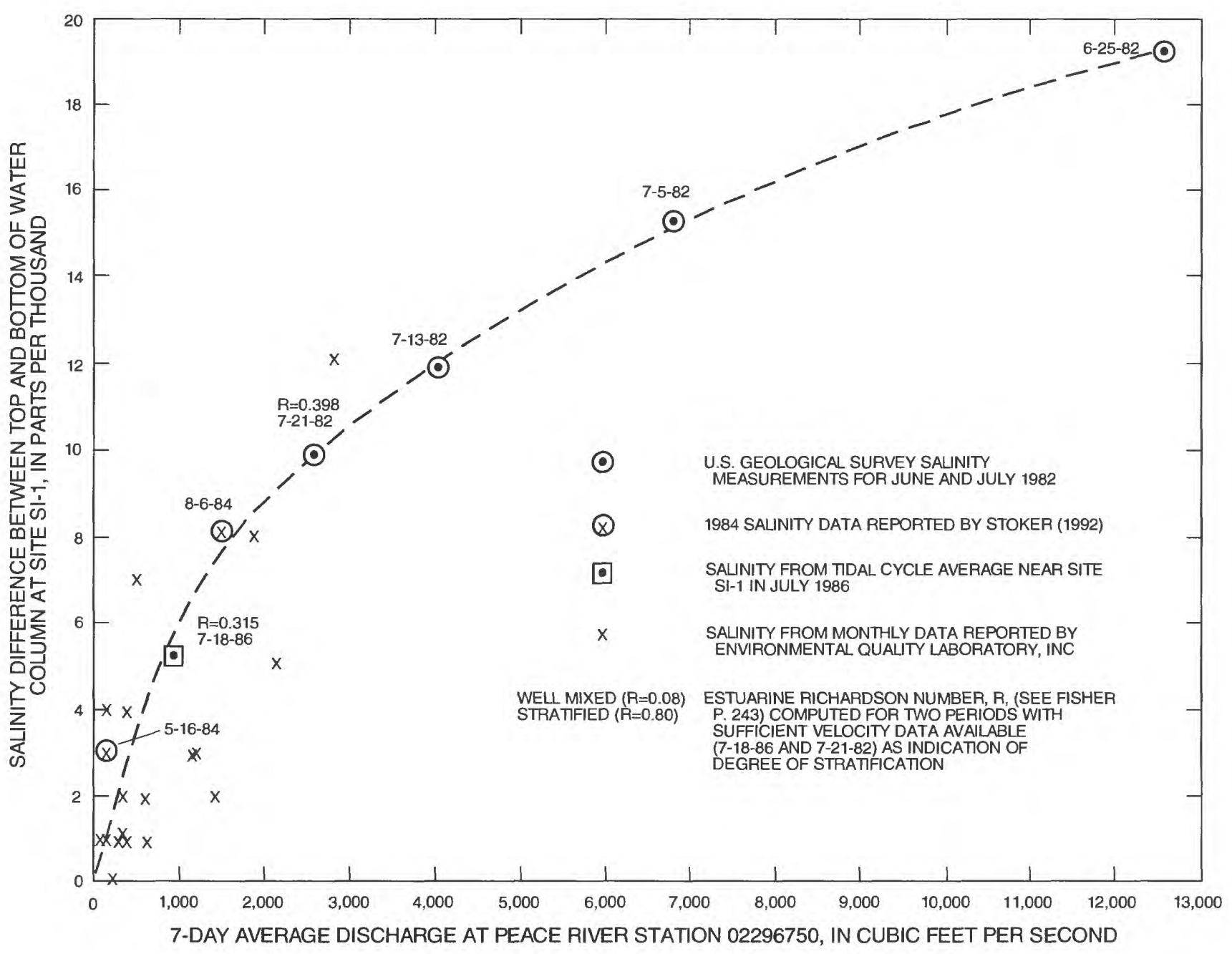

Figure 8. Relation between freshwater inflow from the Peace River and the vertical salinity gradient in northern Charlotte Harbor. 


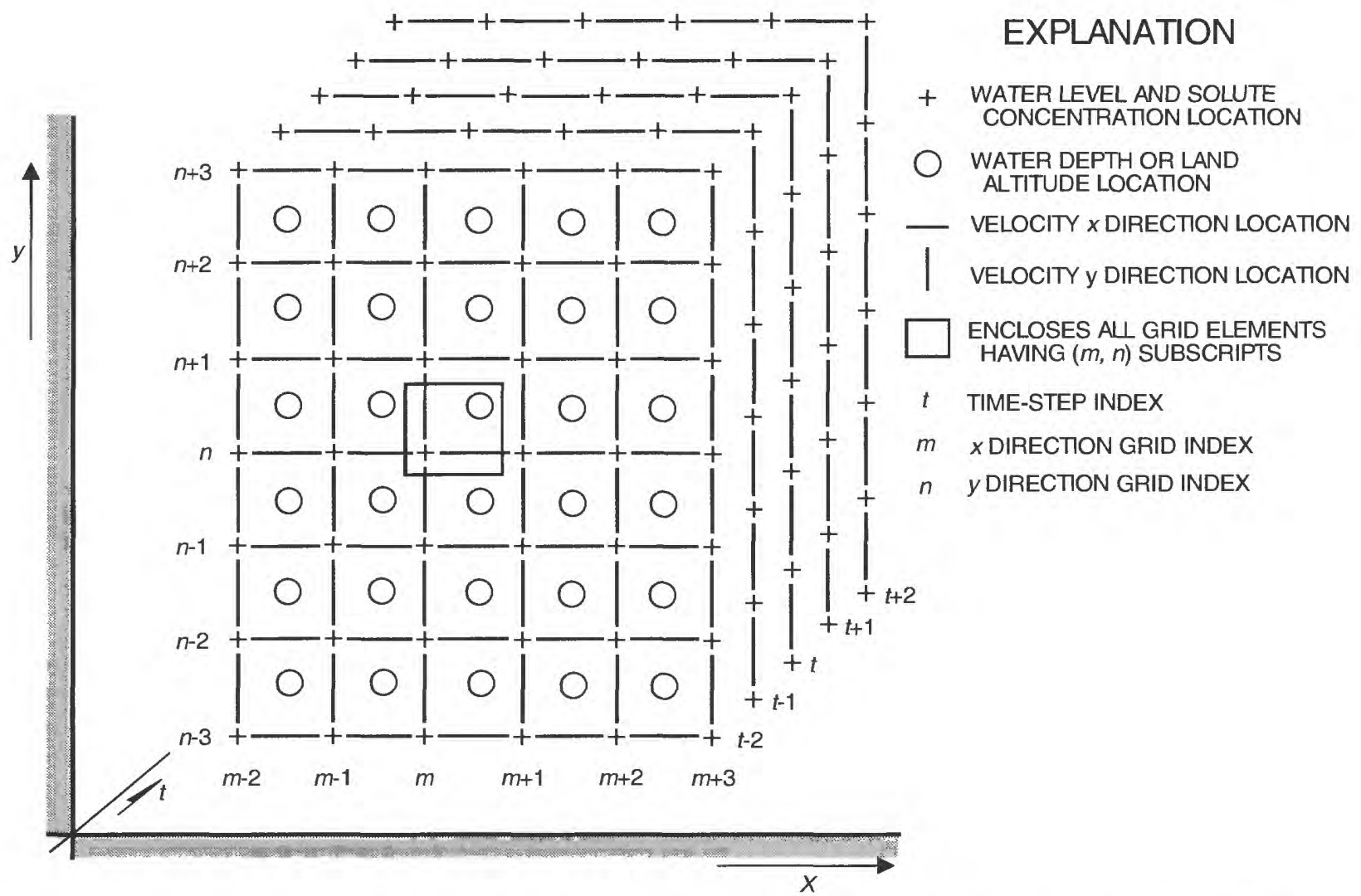

Figure 9. Finite-difference scheme for computer simulation model. (From Goodwin, 1987.) 


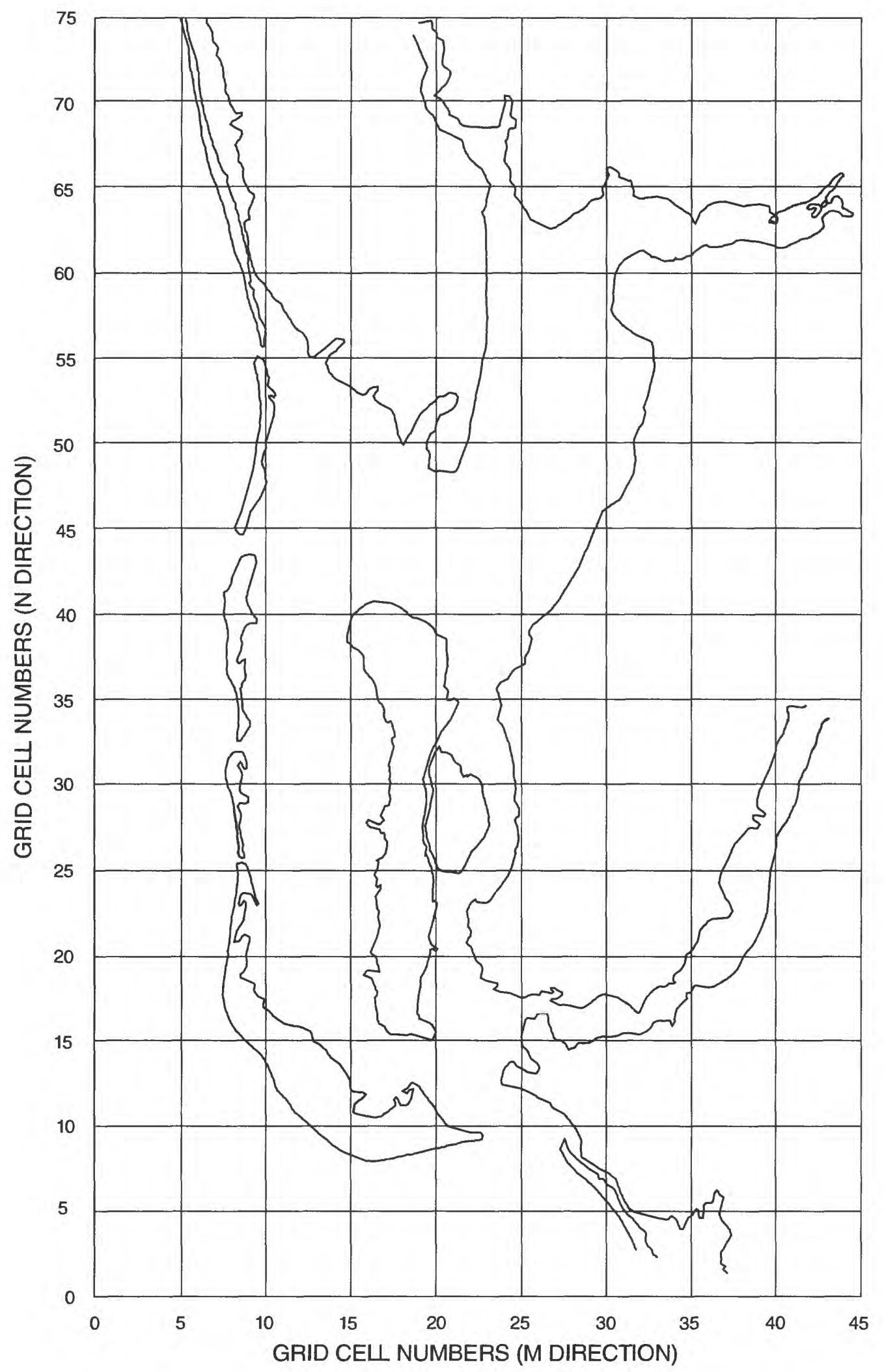

Figure 10. Grid used for the Charlotte Harbor estuarine system model. 


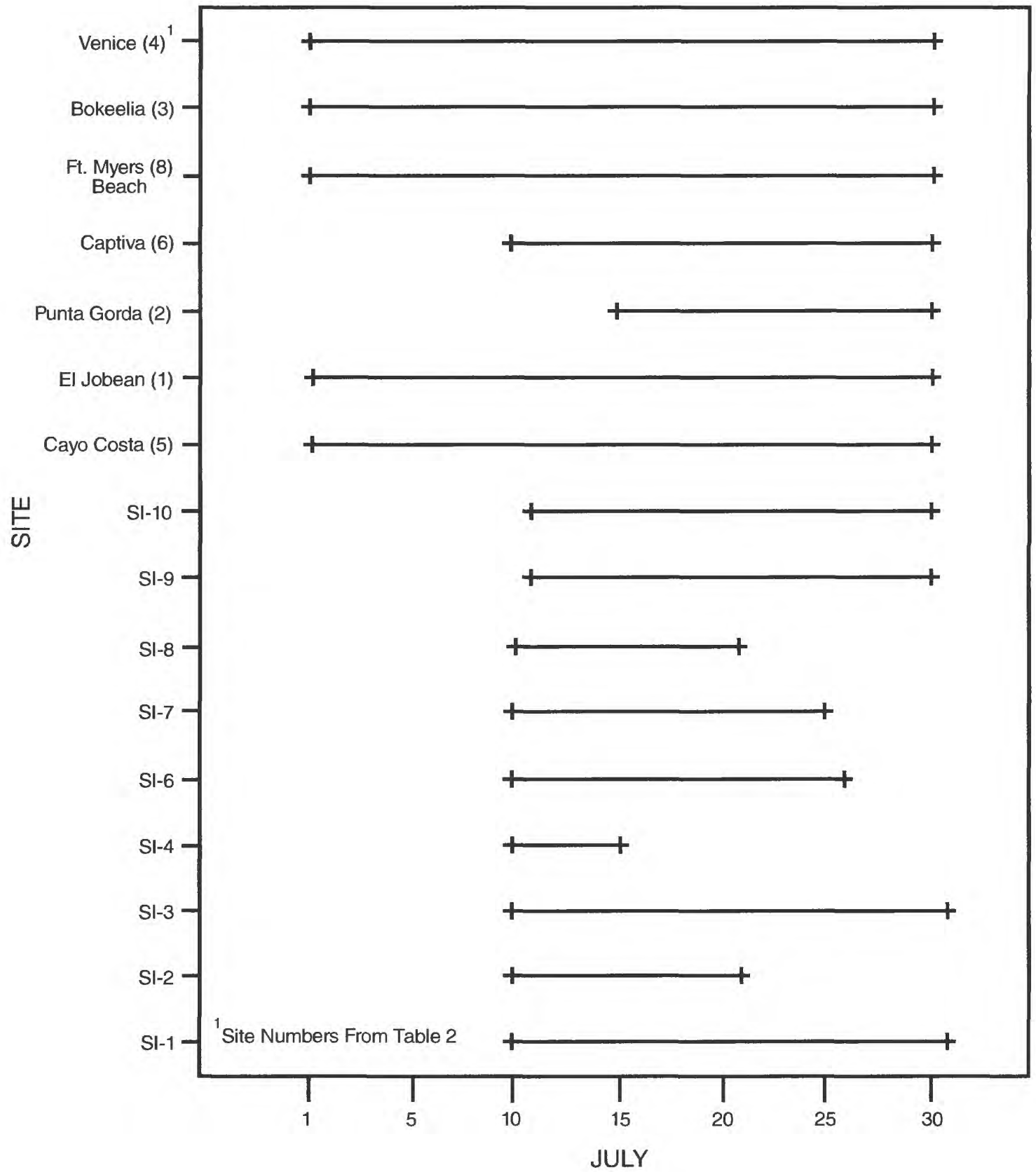

Figure 11. Data available for model calibration and verification. 


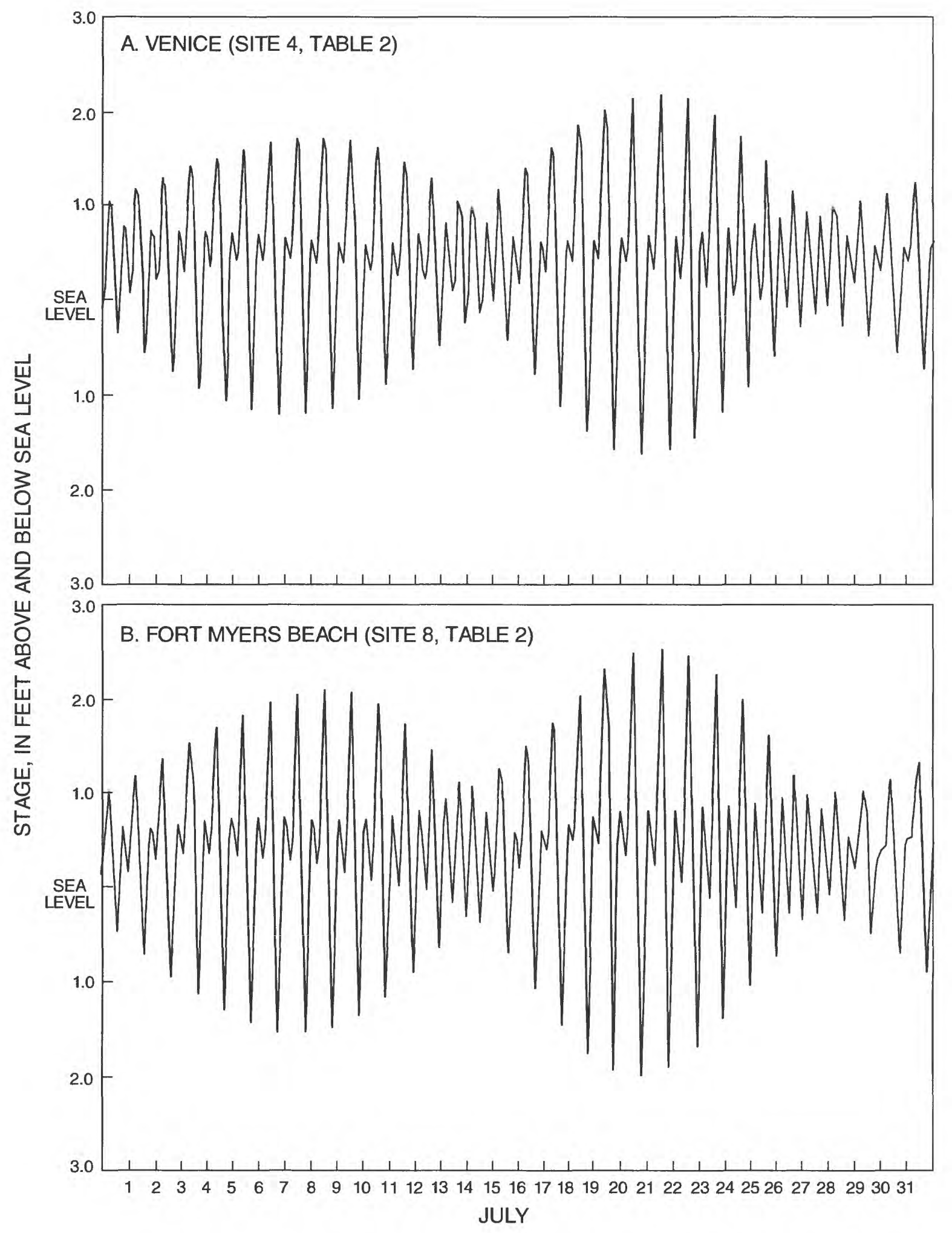

Figure 12. Tidal driving functions used for model calibration and verification at (a) Venice and (b) Fort Myers Beach. 
0.427 feet

Initial water surface $\nabla$ above sea level
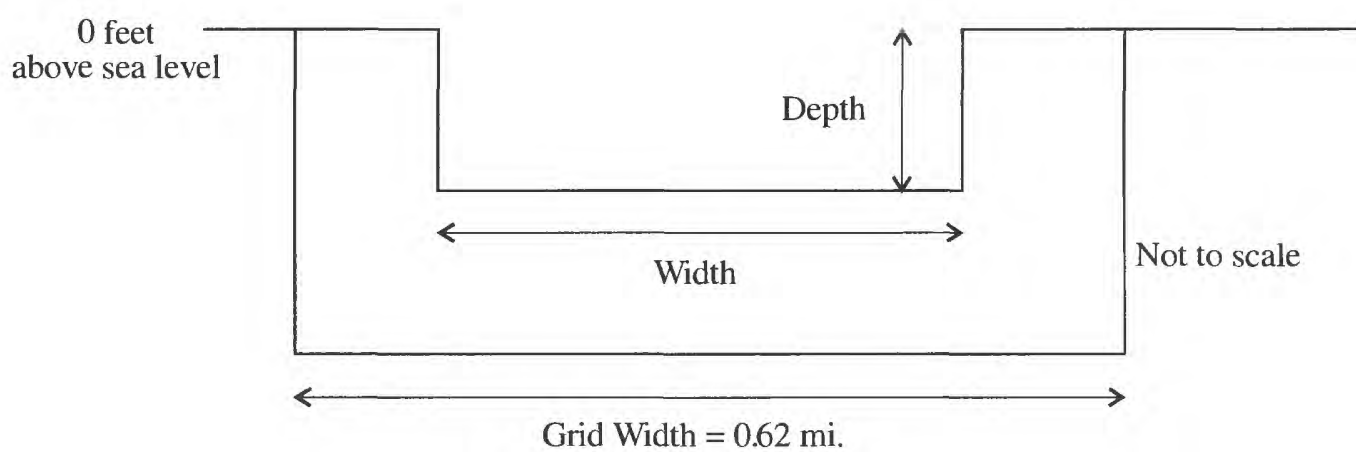

FINAL BARRIER-CELL CONFIGURATION

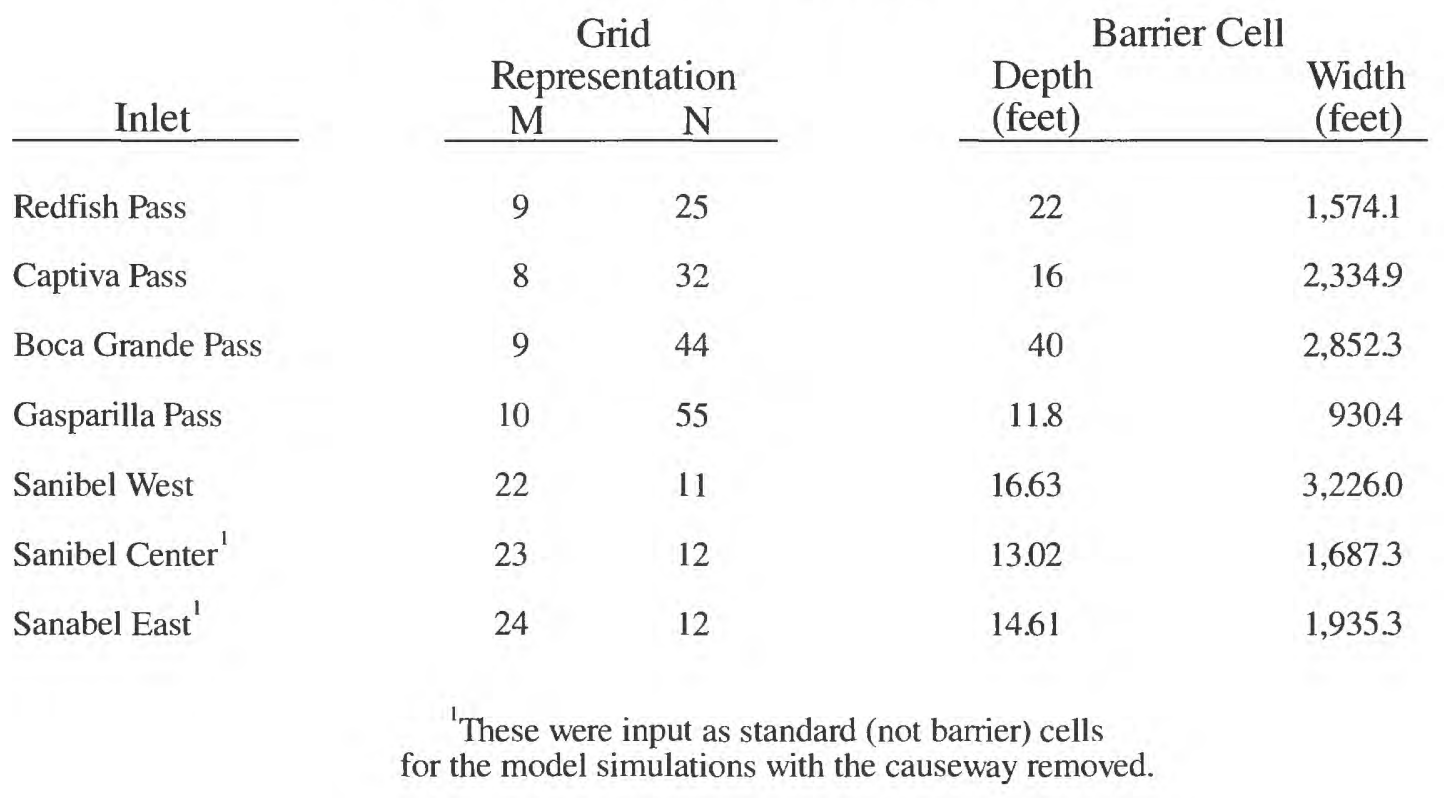

Figure 13. Barrier cell configuration used for tidal inlets. 

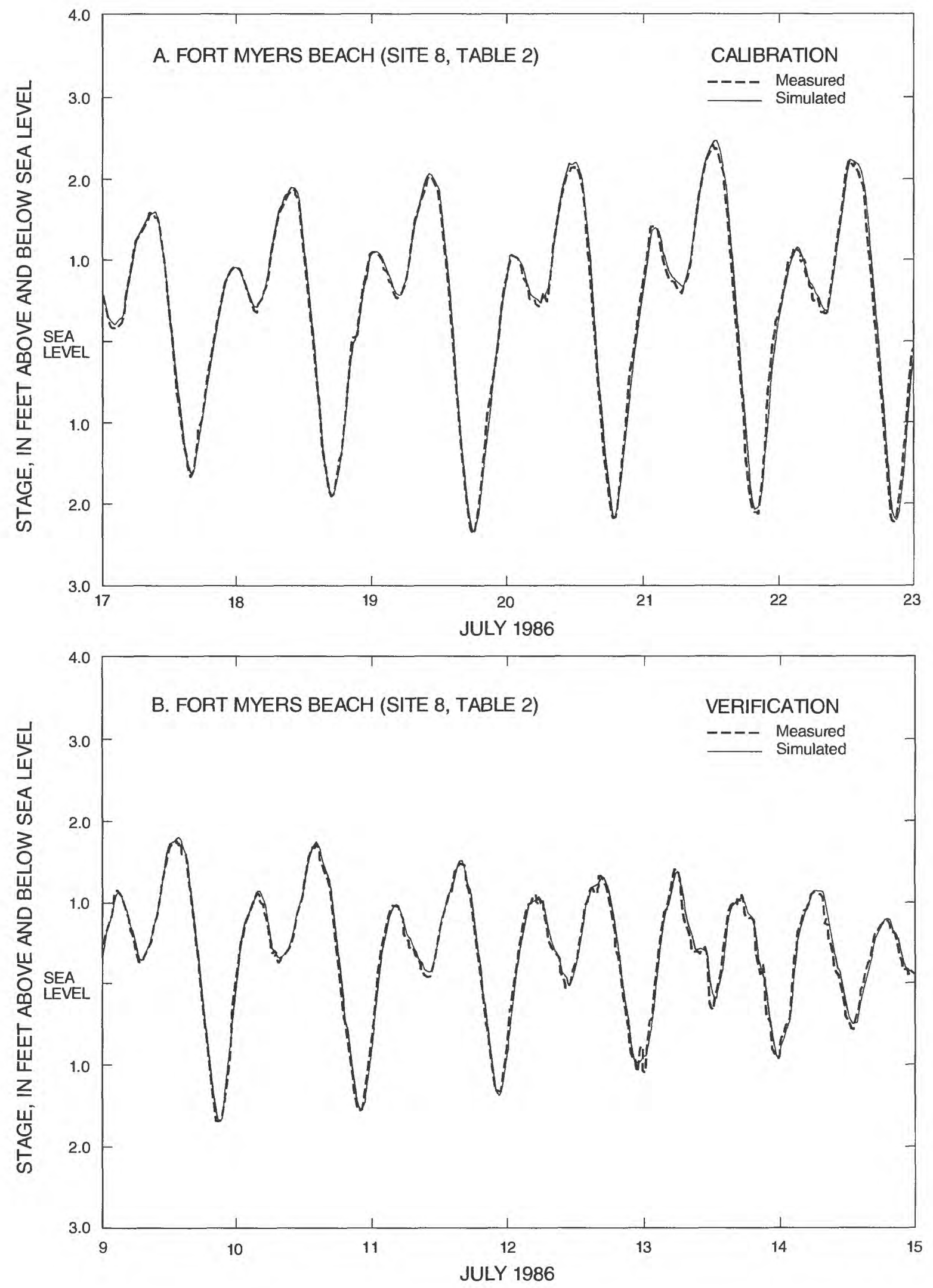

Figure 14. --Simulated and measured tidal stages for the calibration and verification periods. 

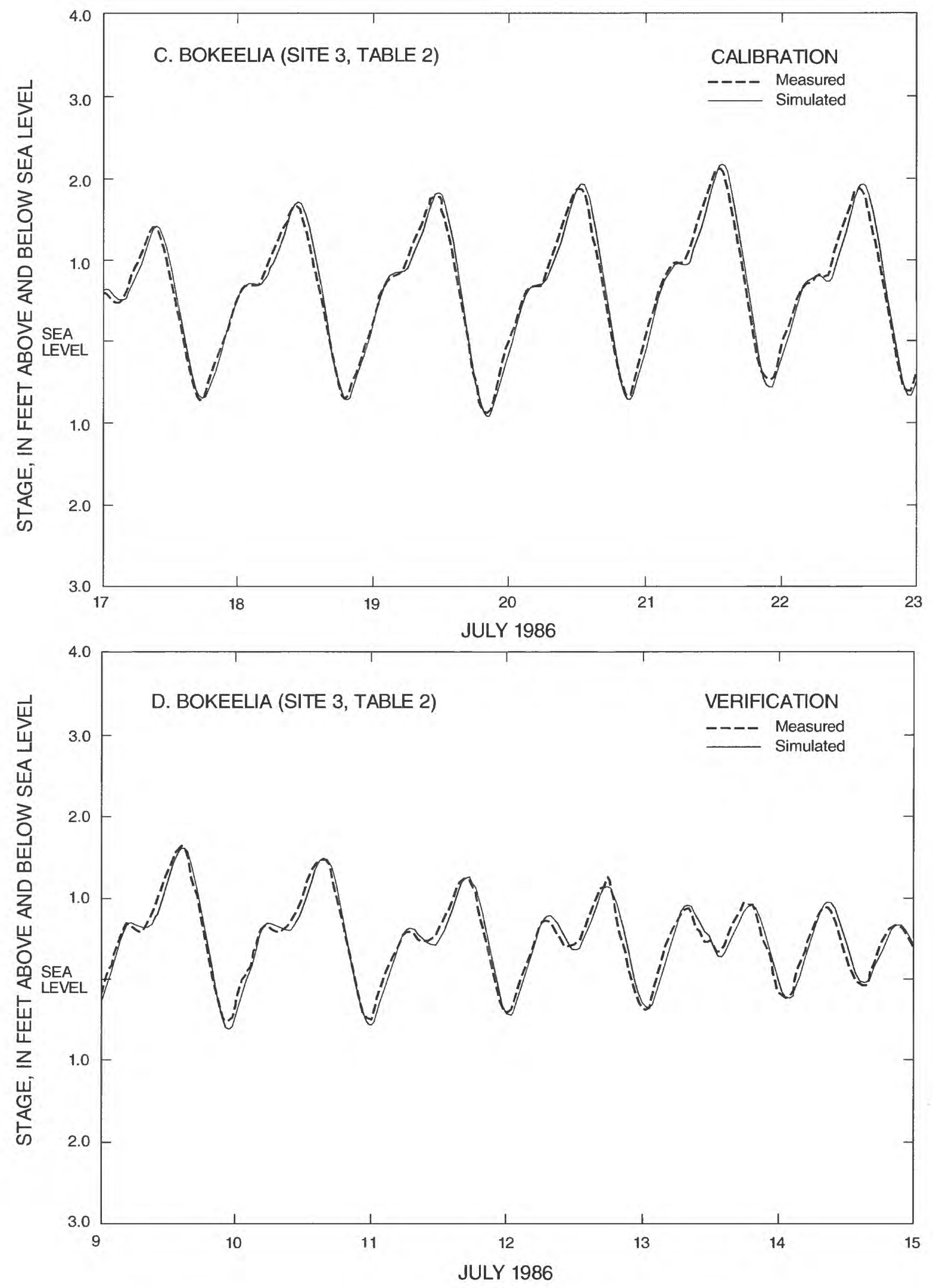

Figure 14. --Continued. Simulated and measured tidal stages for the calibration and verification periods. 

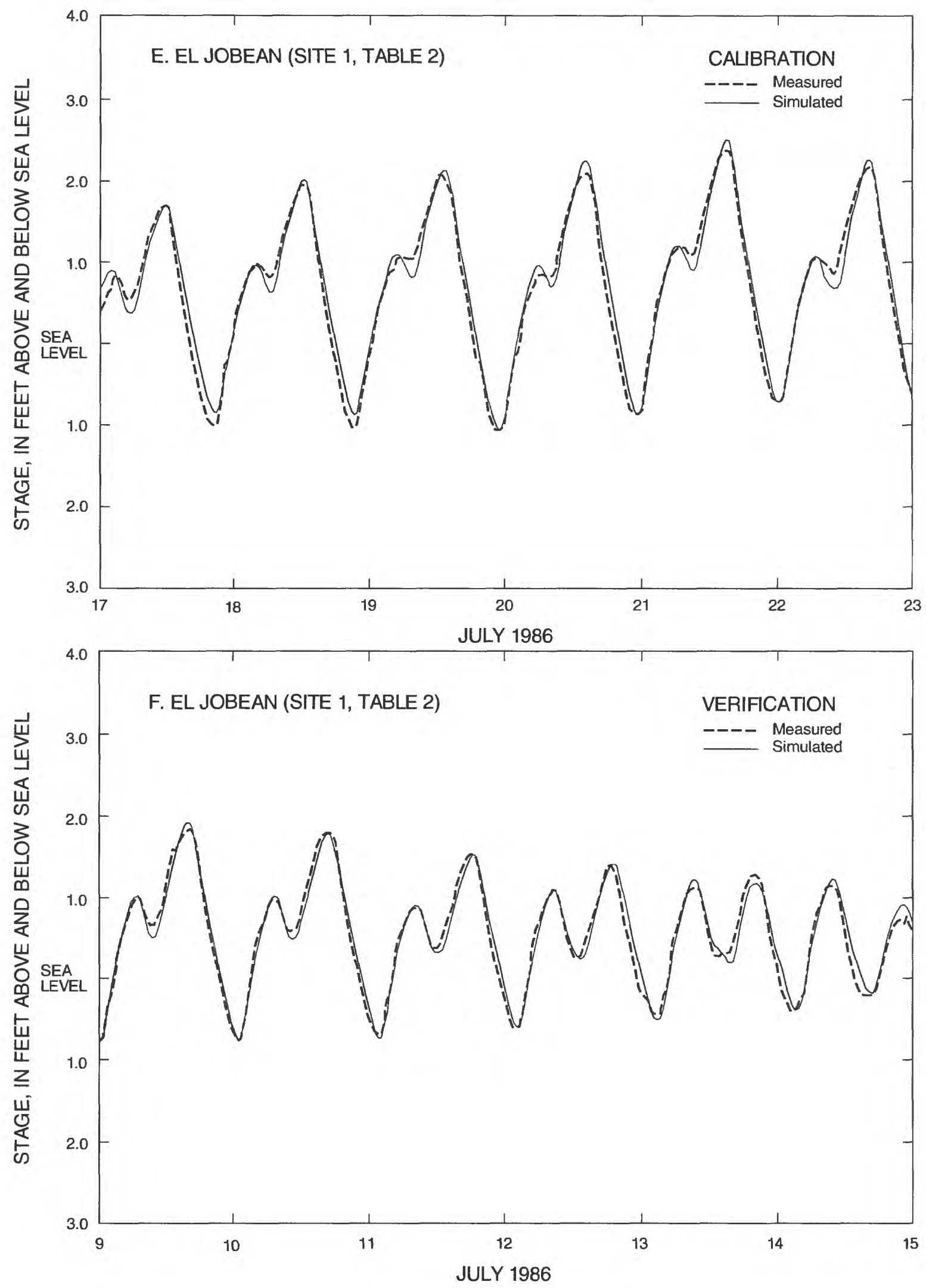

Figure 14. Continued.-- Simulated and measured tidal stages for the calibration and verification periods. 


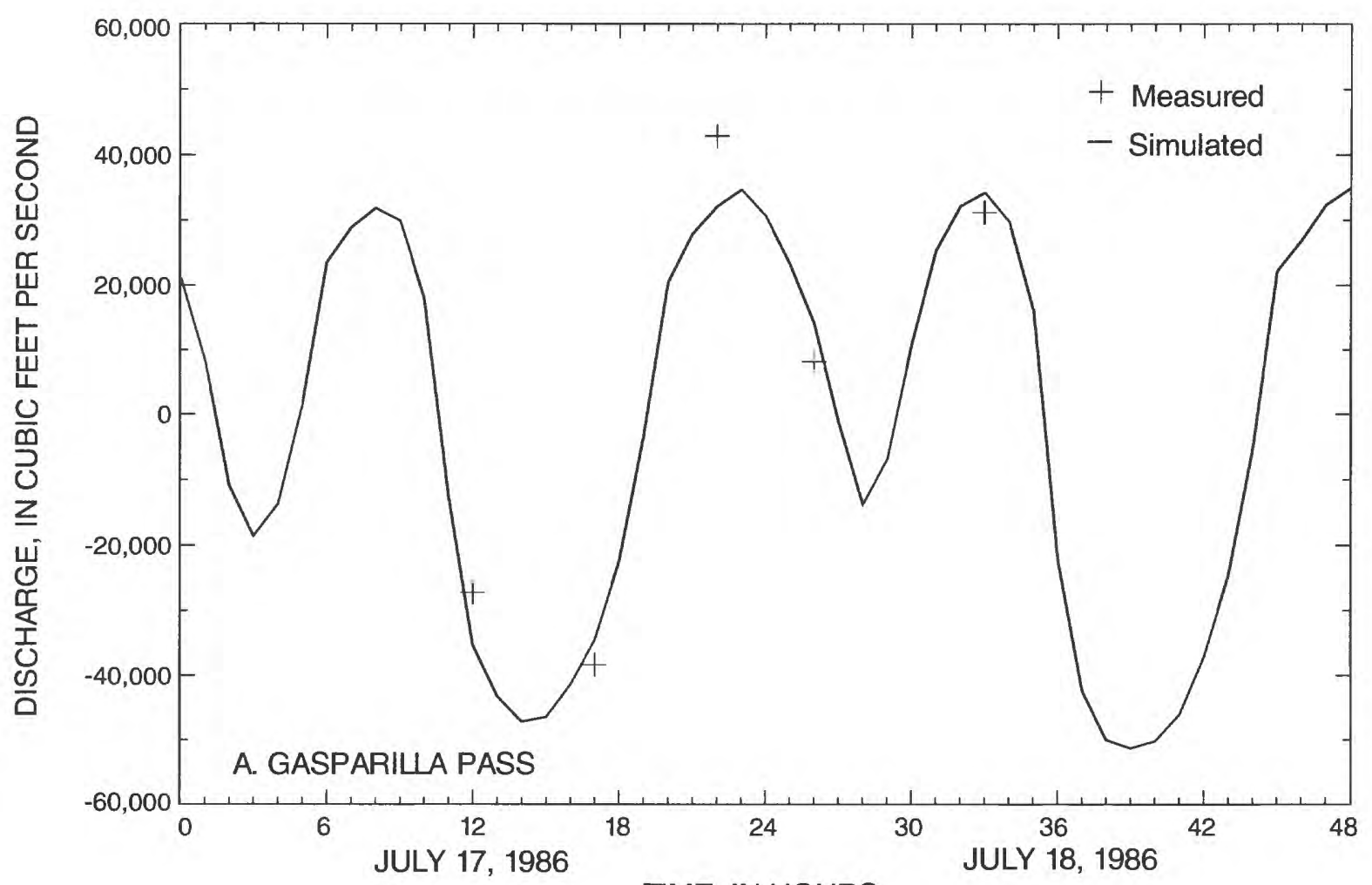

TIME, IN HOURS

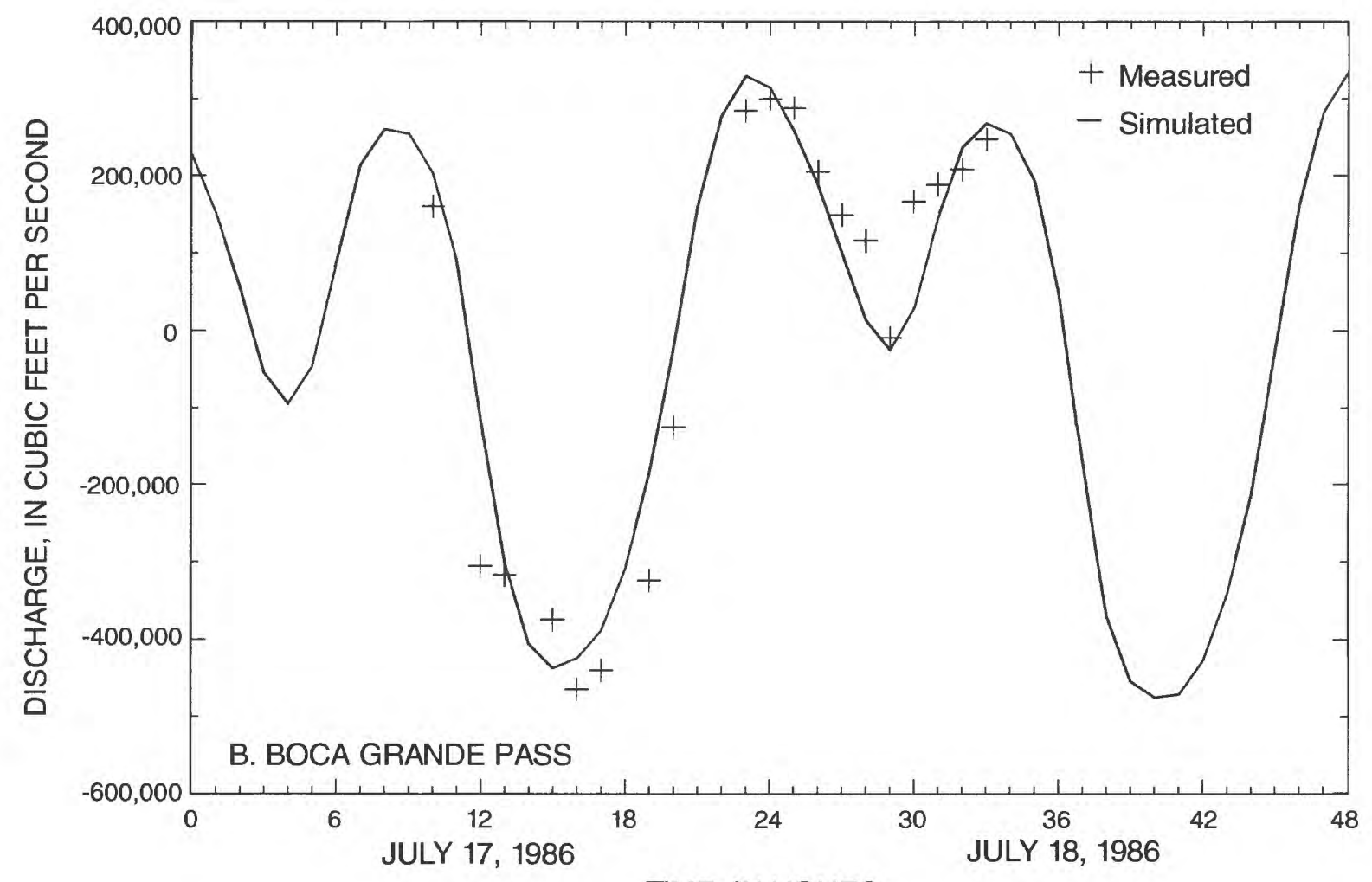

TIME, IN HOURS

Figure 15. Simulated and measured inlet discharges during the calibration period. 

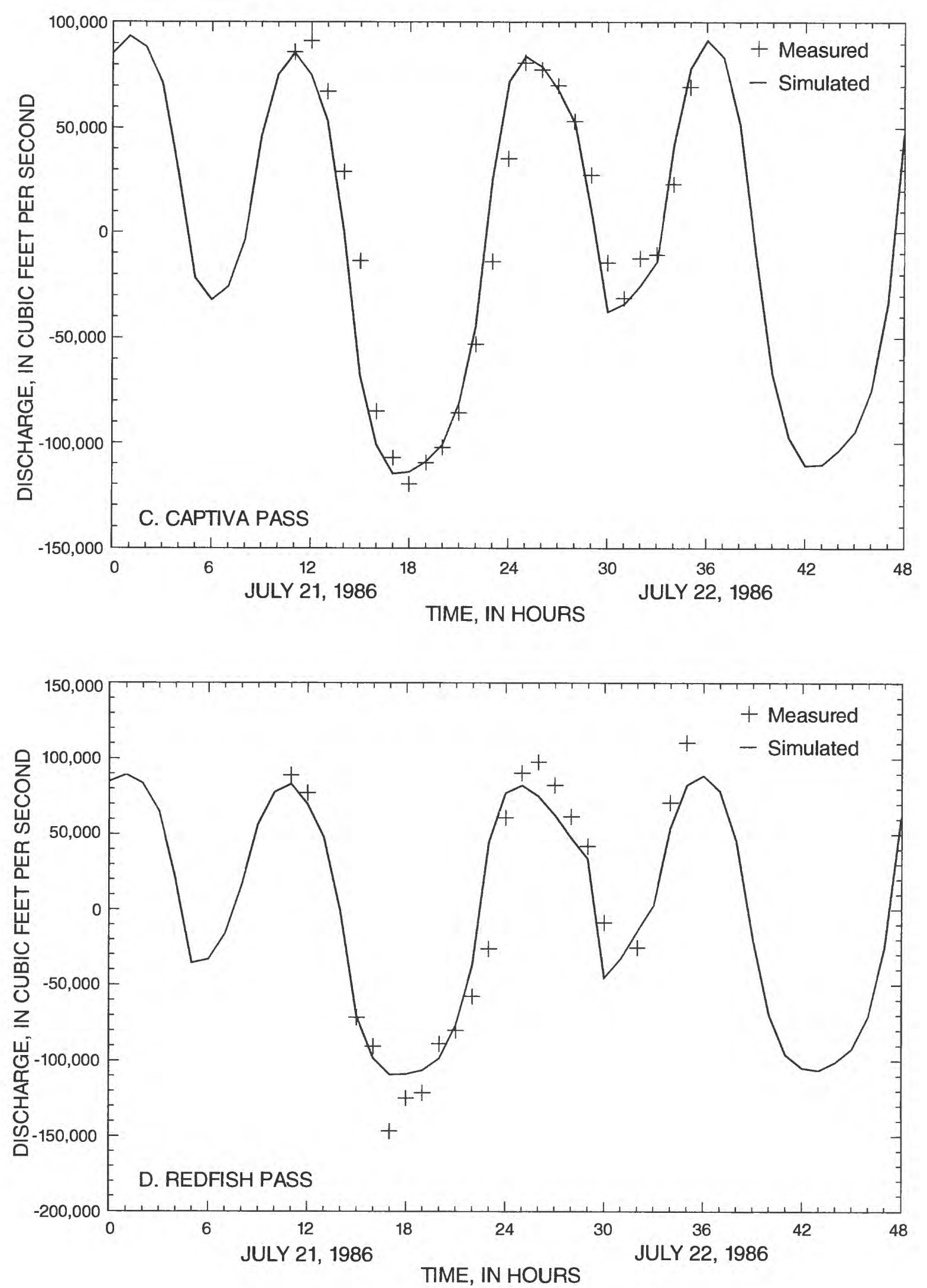

Figure 15. Continued.-- Simulated and measured inlet discharges during the calibration period. 


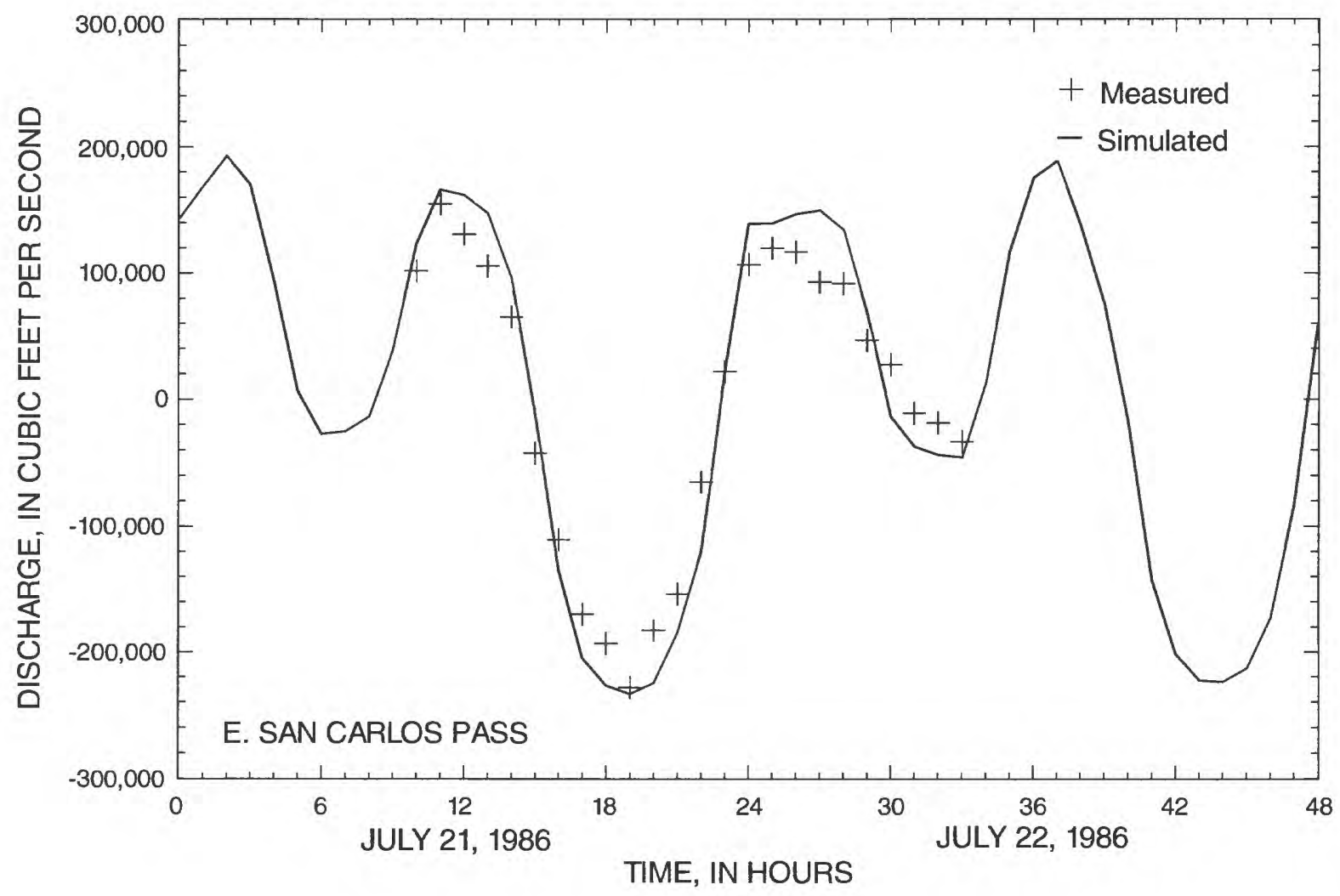

Figure 15. Continued.-- Simulated and measured inlet discharges during the calibration period. 

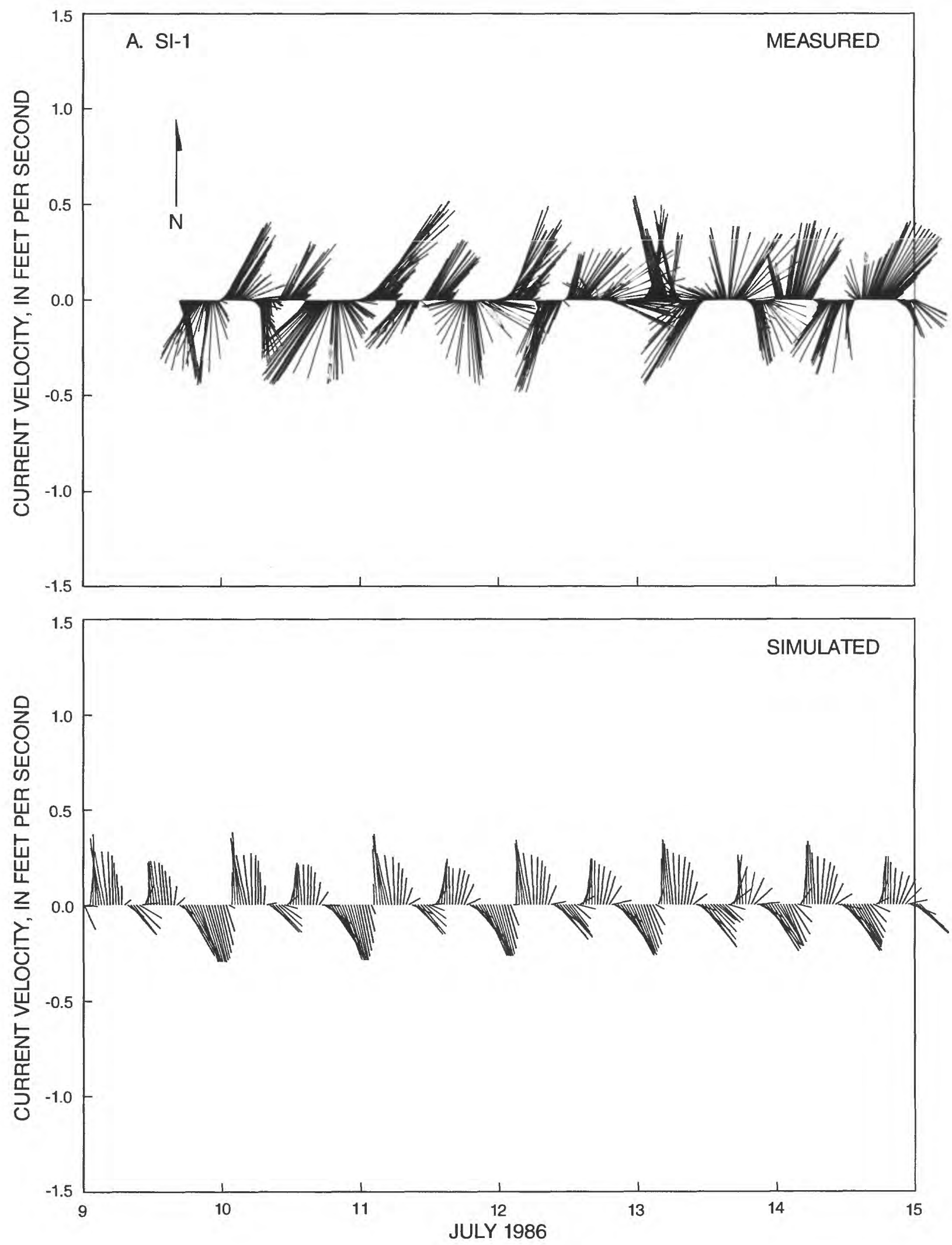

Figure 16. Simulated and measured velocity data for the verification period. 

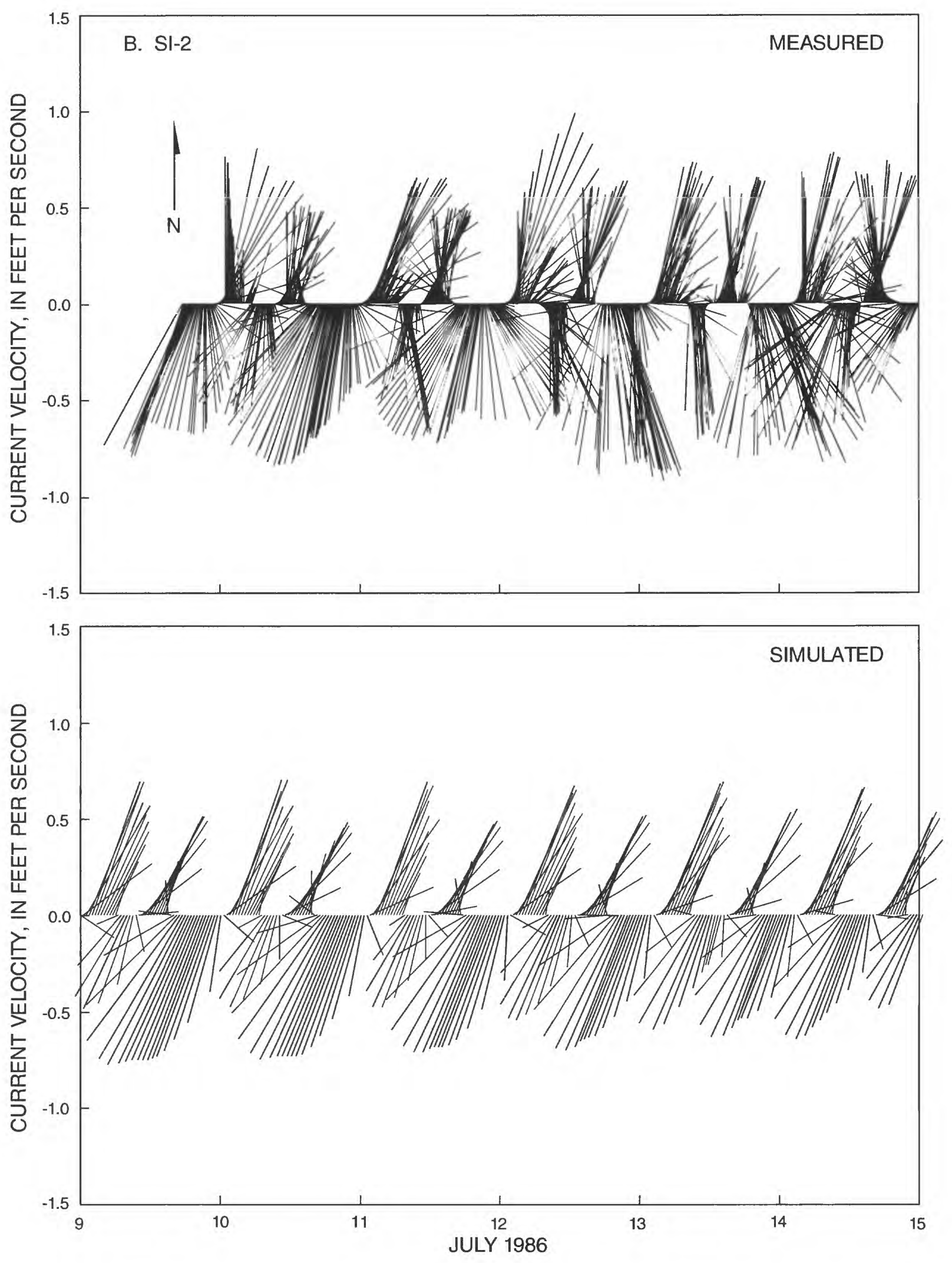

Figure 16. Continued.-- Simulated and measured velocity data for the verification period. 

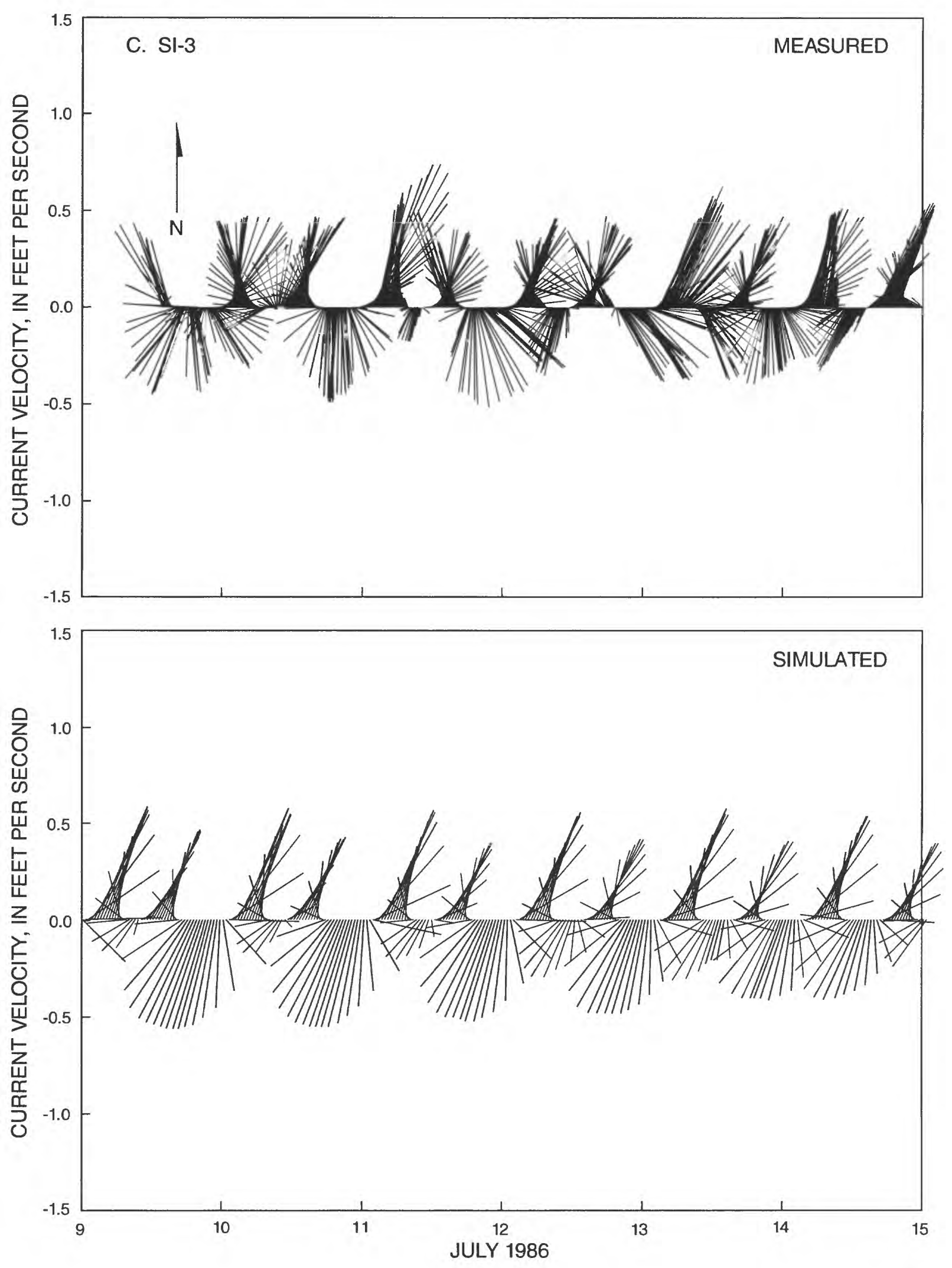

Figure 16. Continued.-- Simulated and measured velocity data for the verification period. 

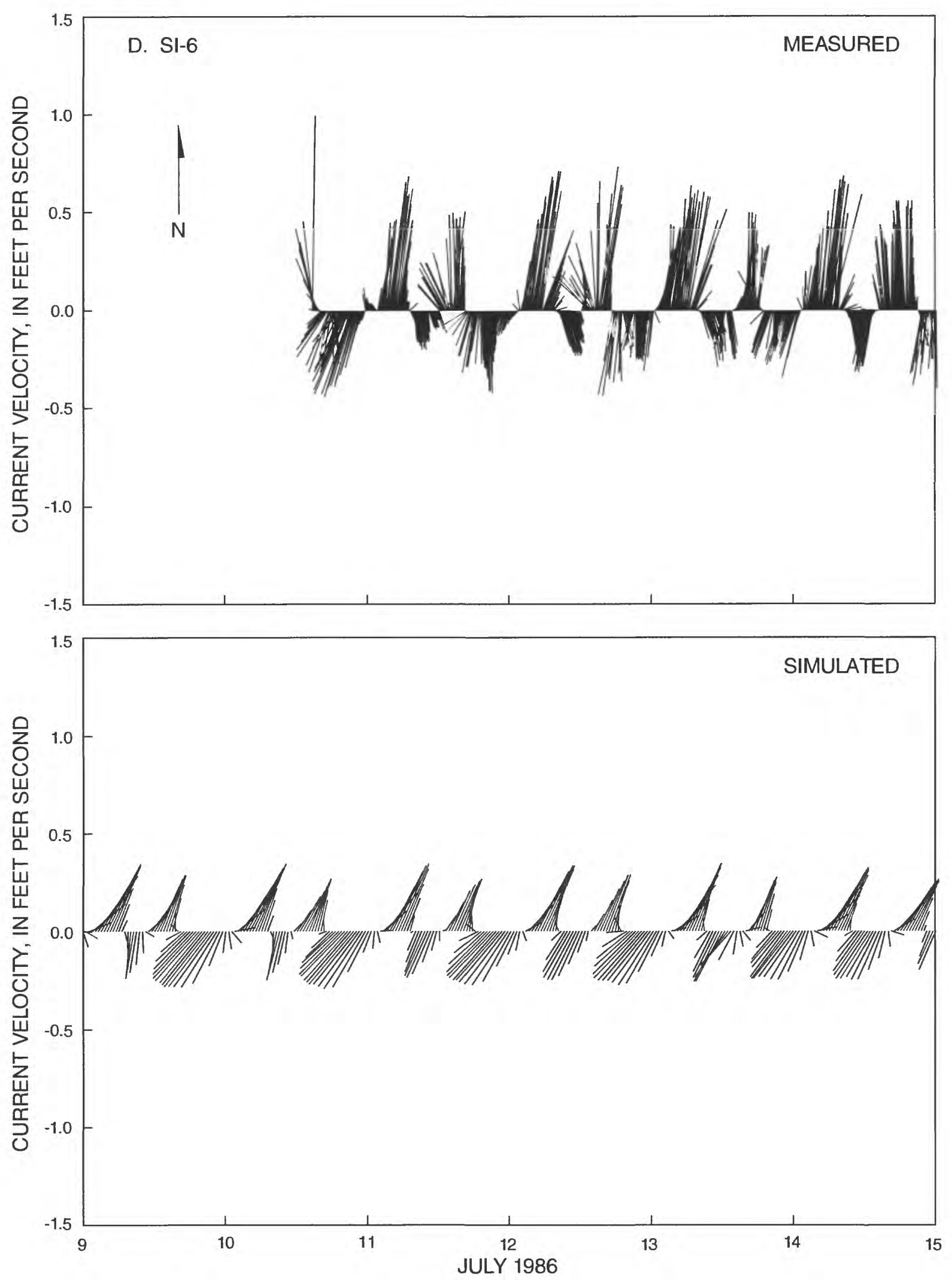

Figure 16. Continued.-- Simulated and measured velocity data for the verification period. 

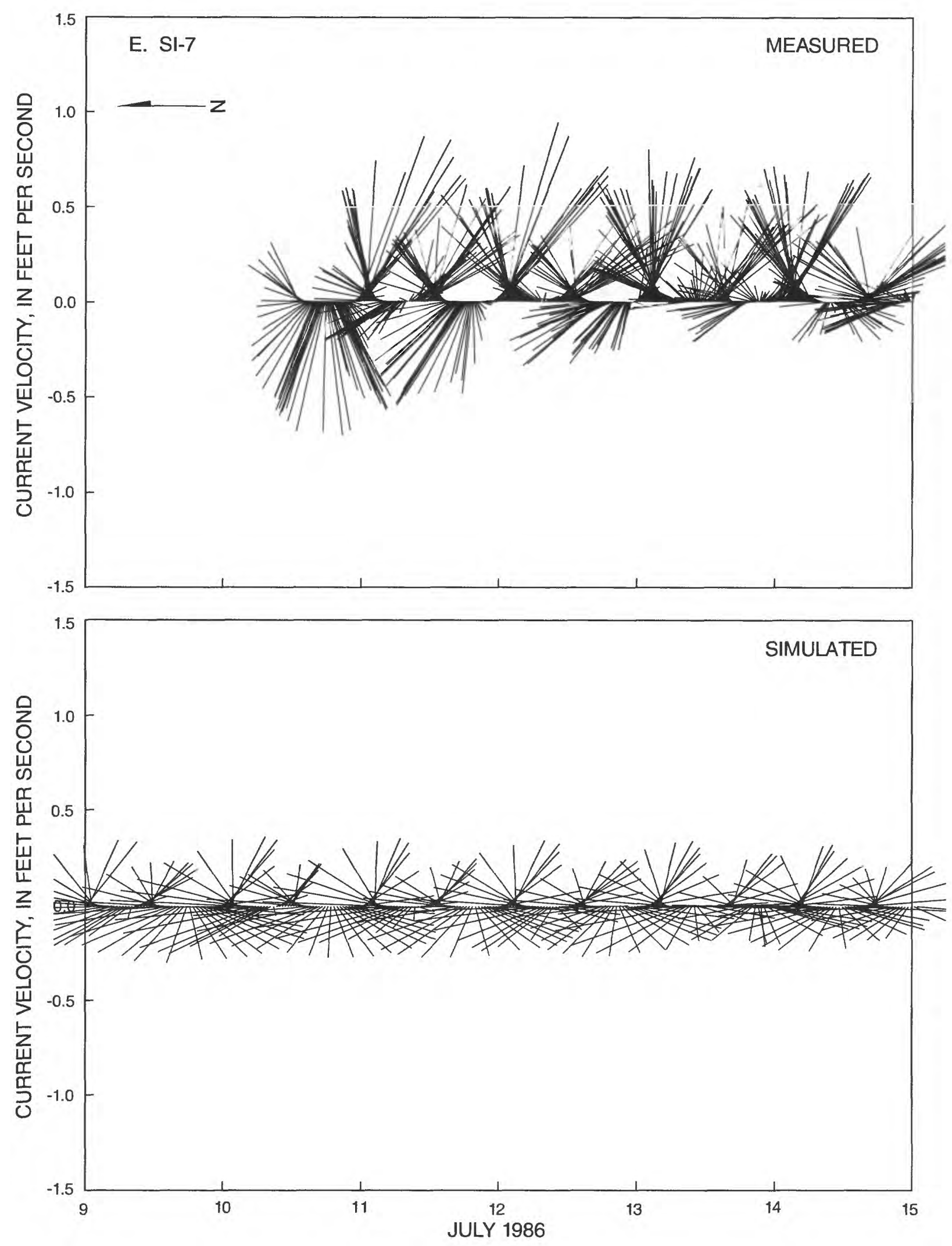

Figure 16. Continued.-- Simulated and measured velocity data for the verification period. 

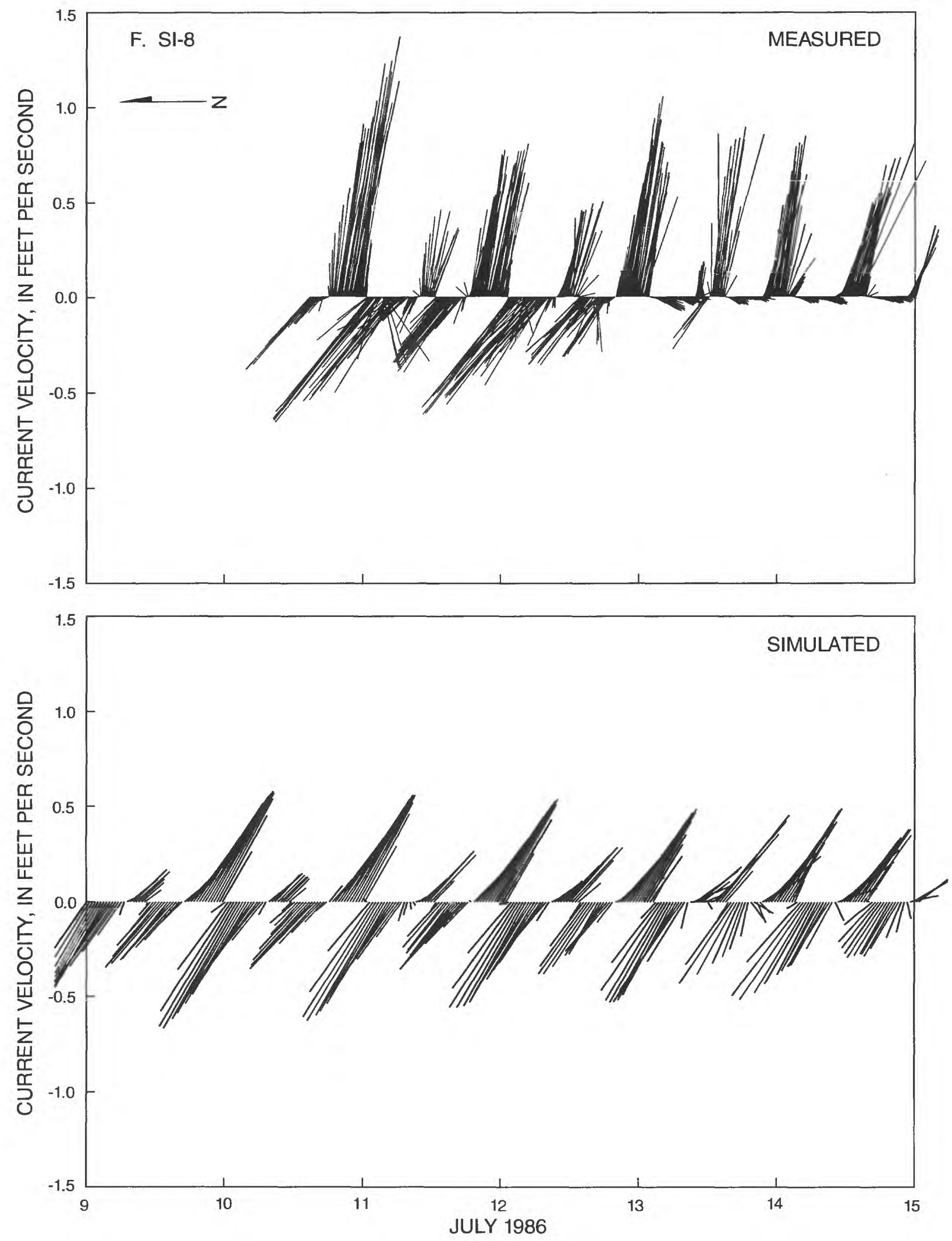

Figure 16. Continued.-- Simulated and measured velocity data for the verification period. 

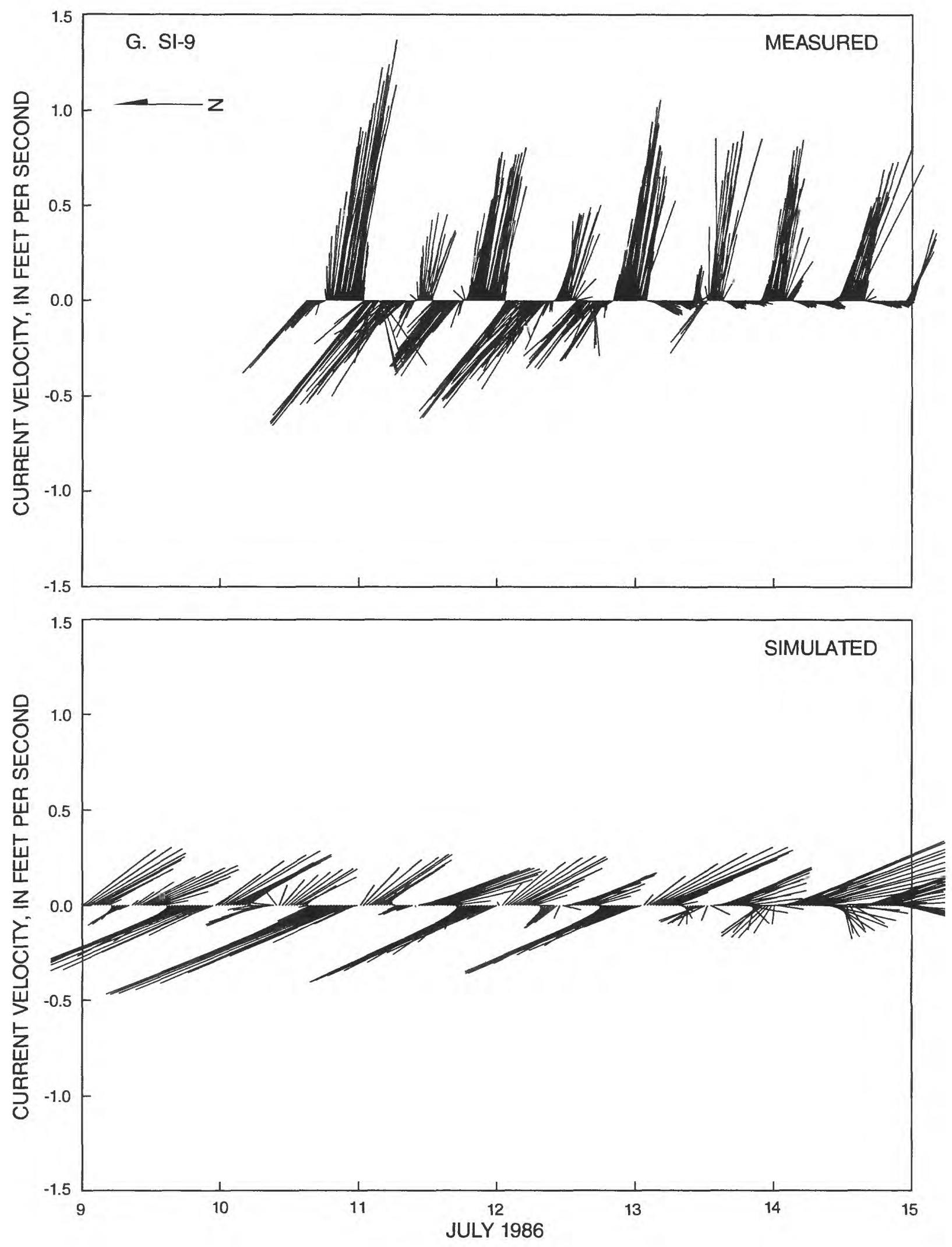

Figure 16. Continued.-- Simulated and measured velocity data for the verification period. 

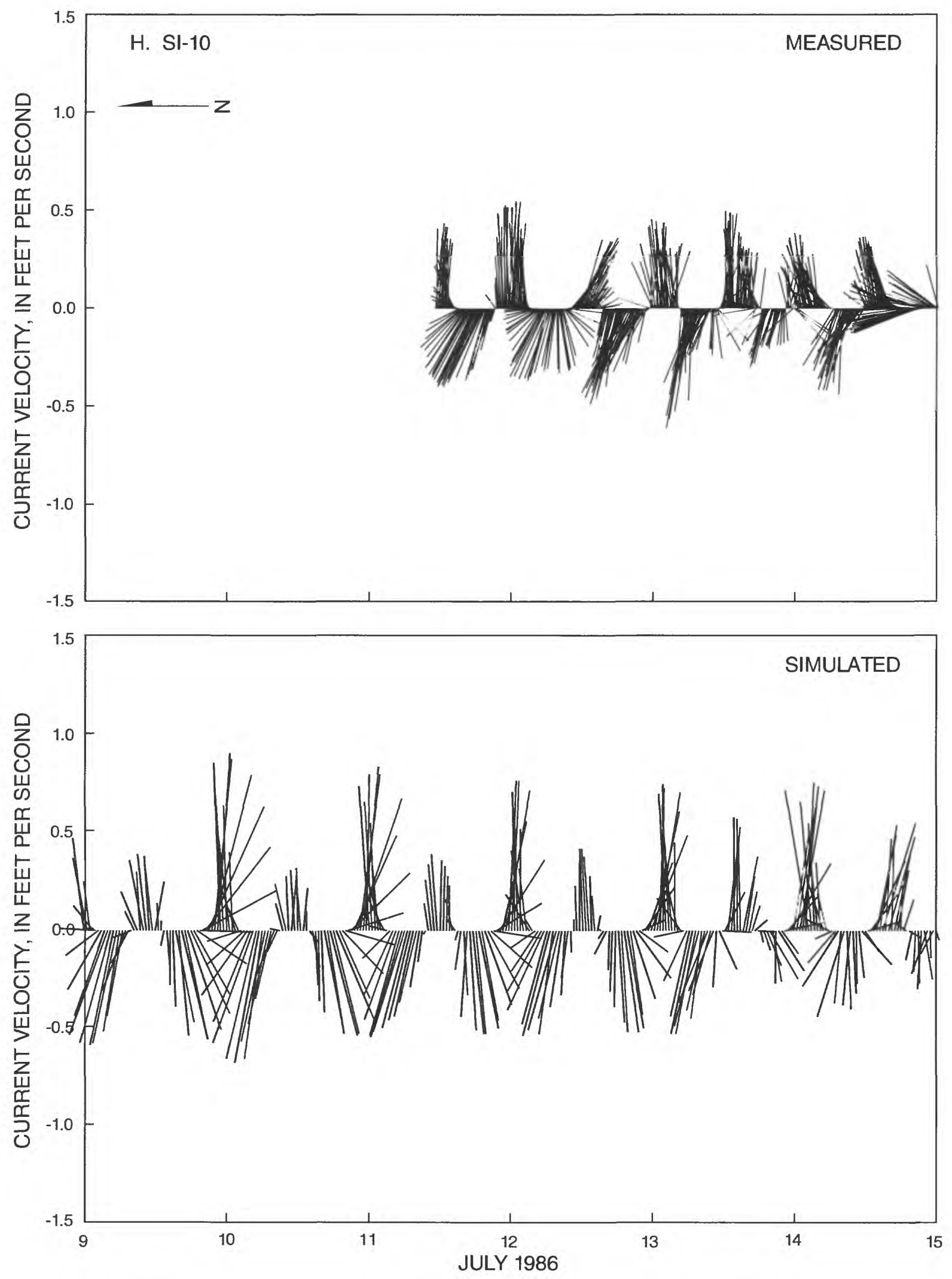

Figure 16. Continued.-- Simulated and measured velocity data for the verification period. 


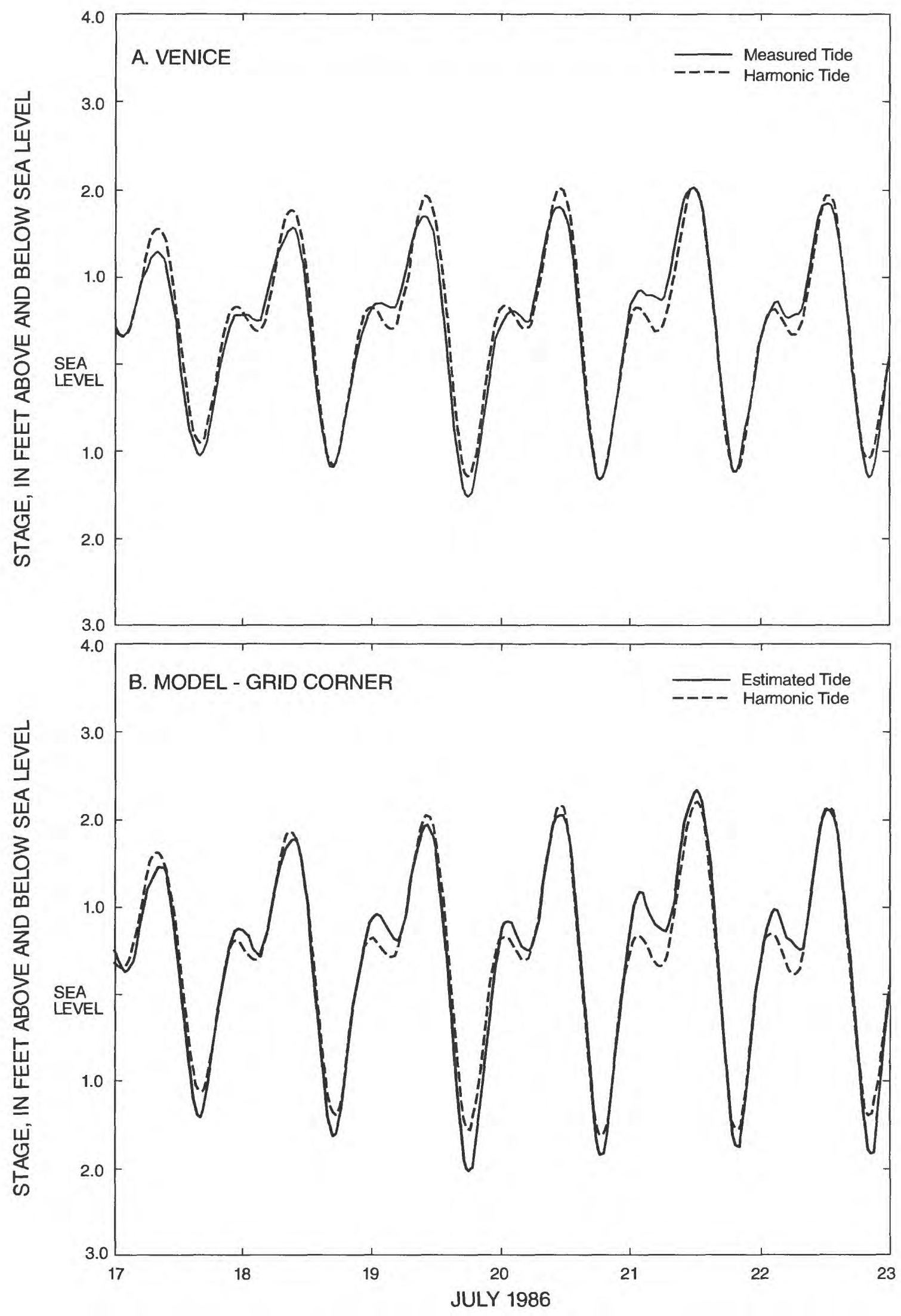

Figure 17. Measured tidal-driving function and tidal-driving function generated from harmonic components. 


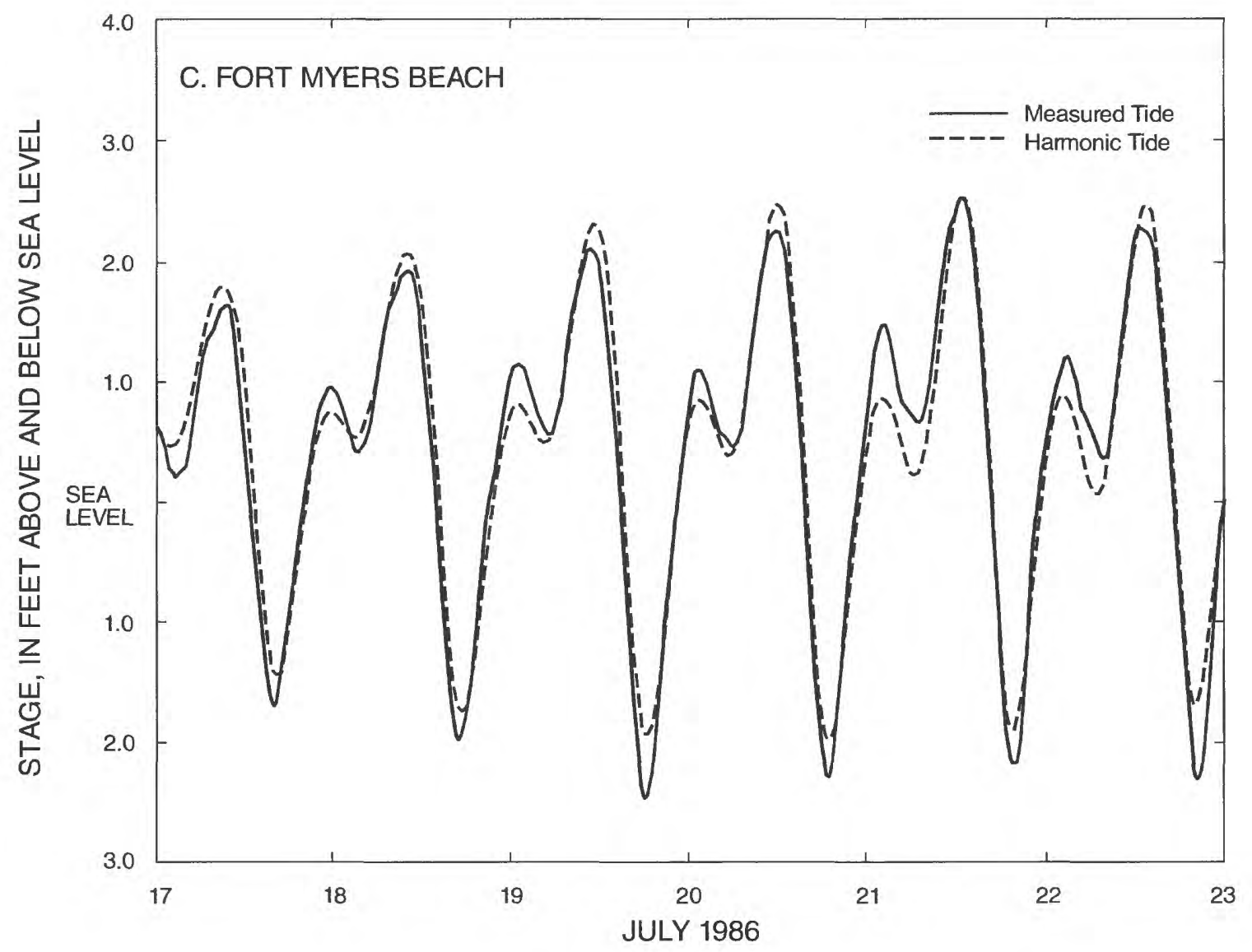

Figure 17. Continued.-- Measured tidal-driving function and tidal-driving function generated from harmonic components. 


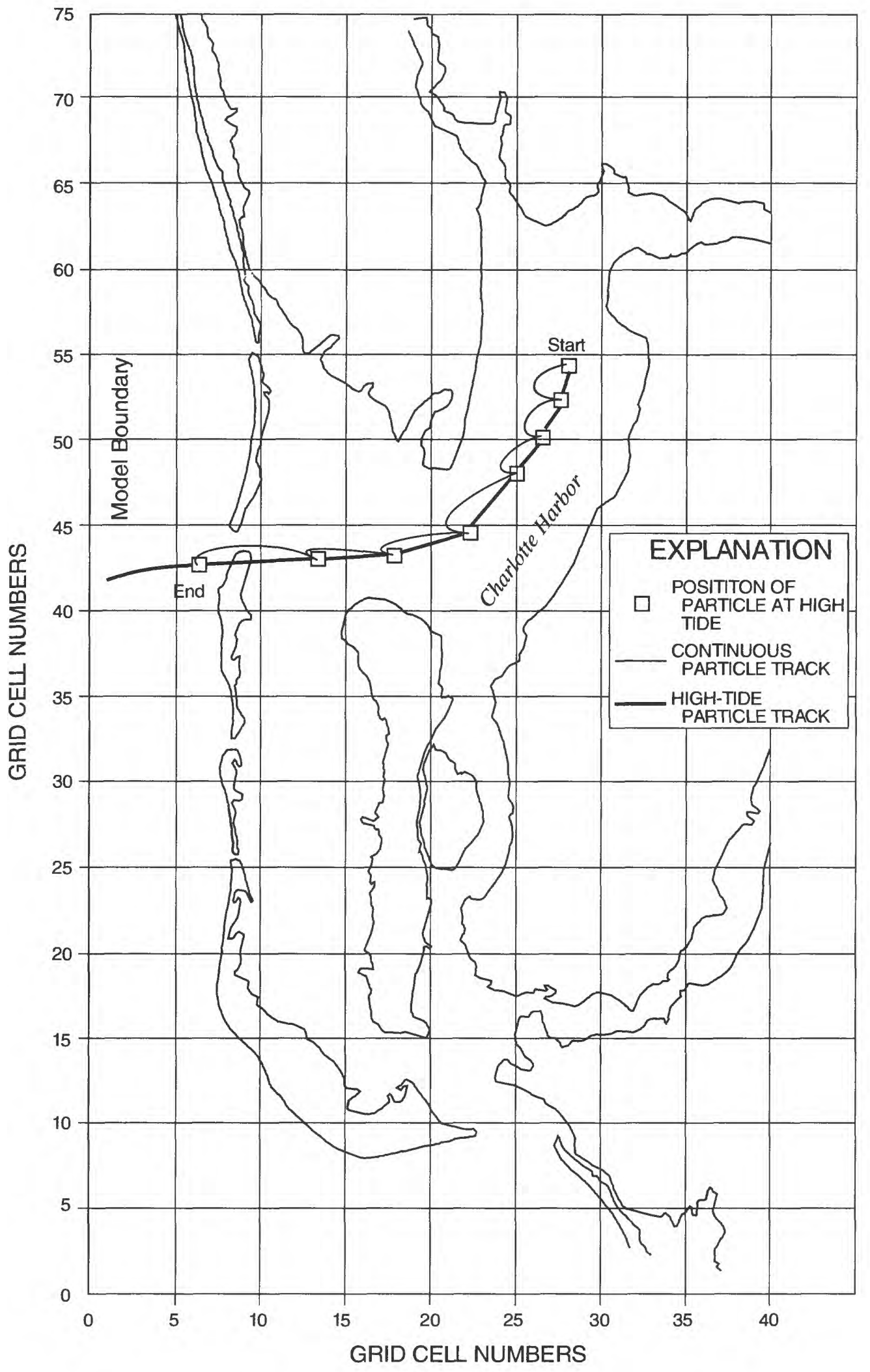

Figure 18. Example of continuous particle and high-tide particle tracks. 


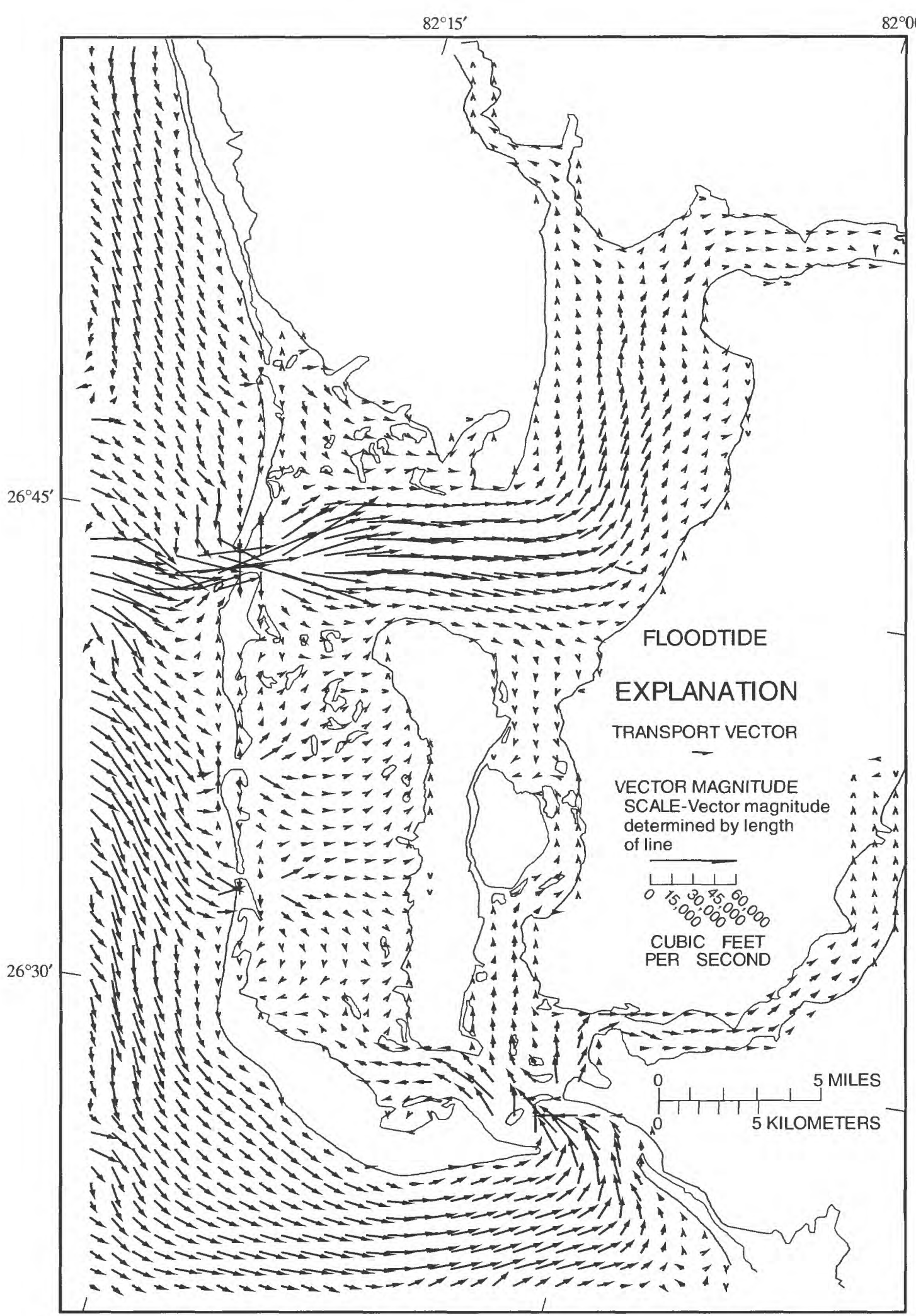

Figure 19. Selected water-transport vectors during floodtide under typical freshwater inflow conditions. 


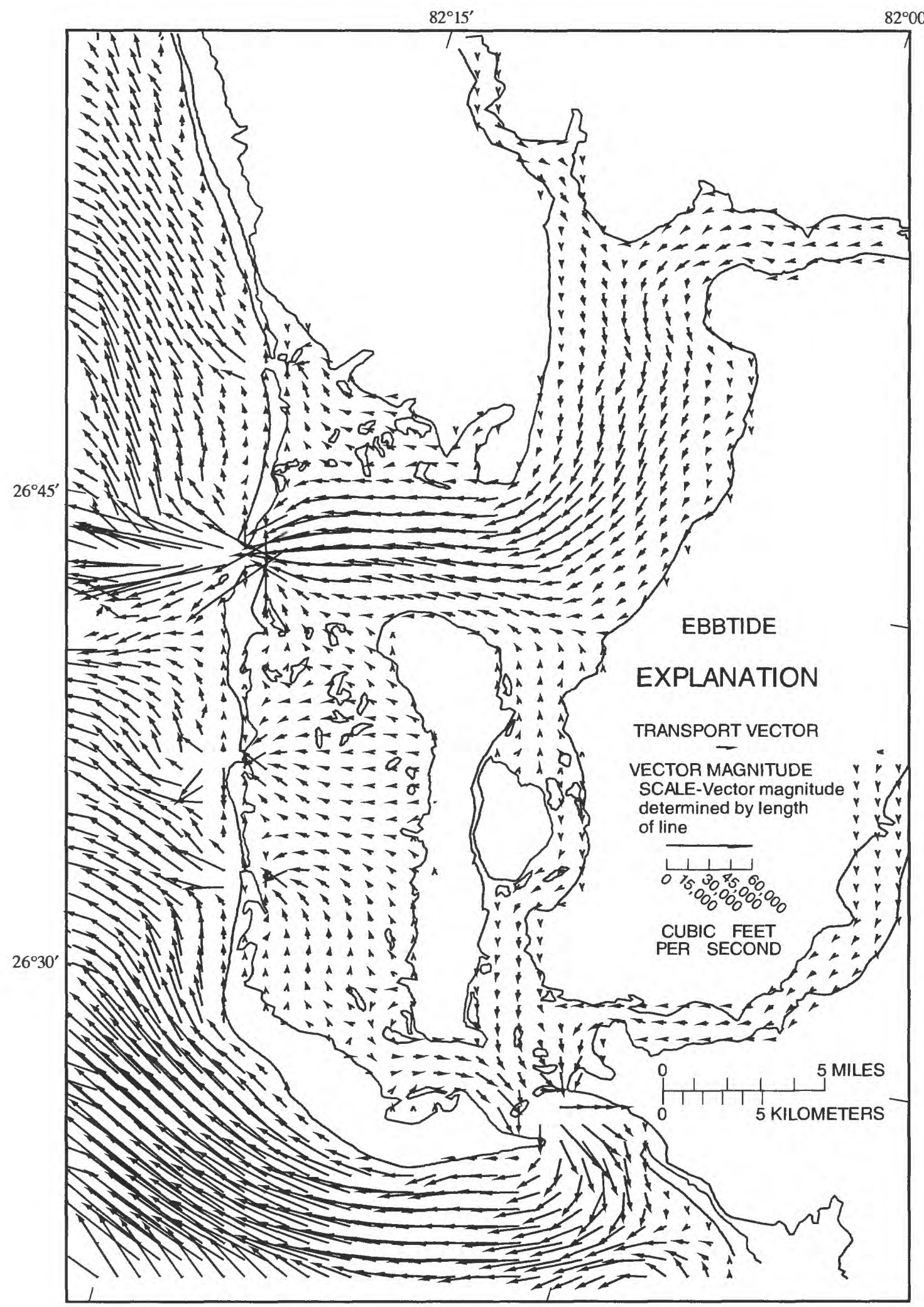

Figure 20. Selected water-transport vectors during ebbtide under typical freshwater inflow conditions. 


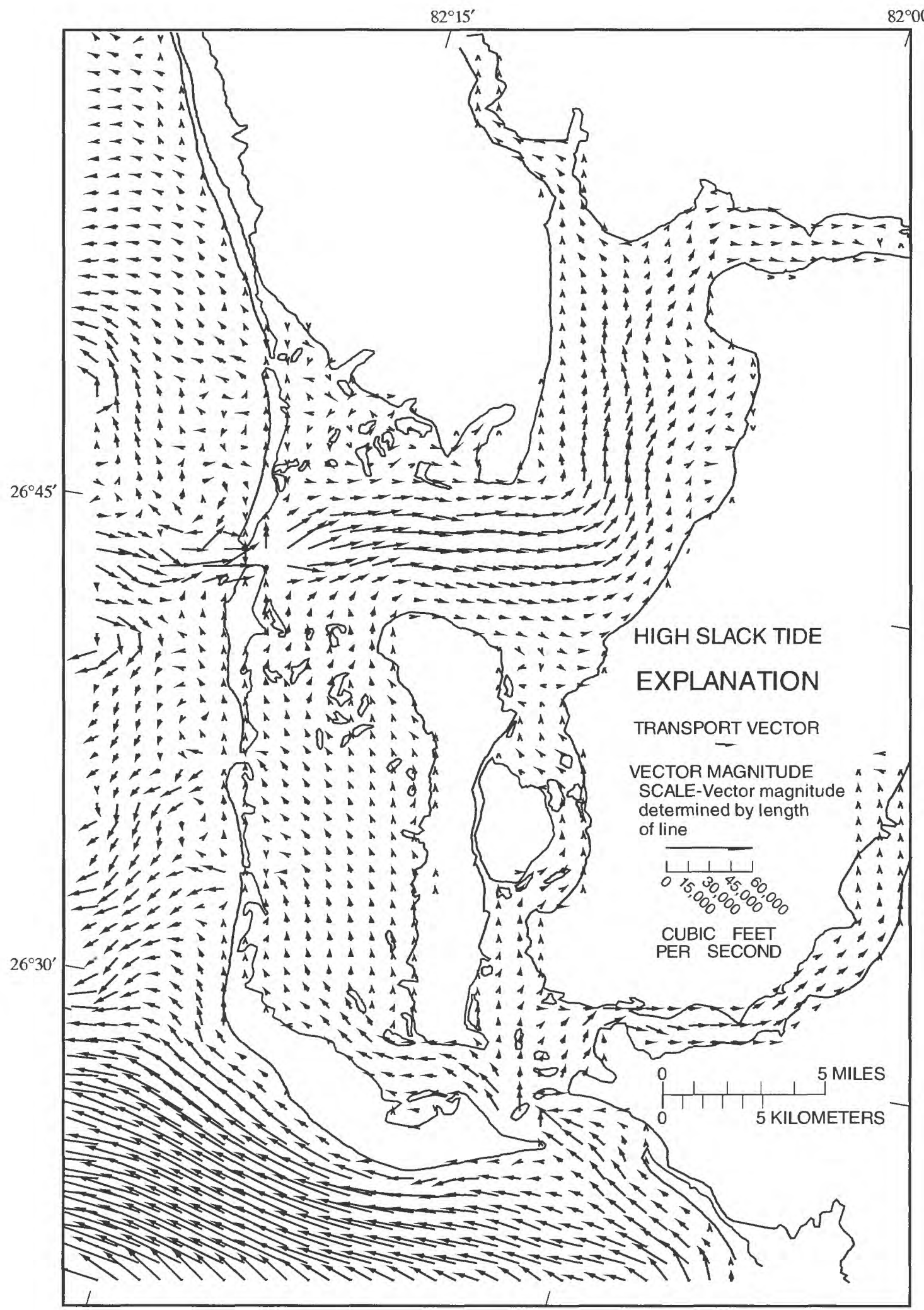

Figure 21. Selected water-transport vectors during high-slack tide under typical freshwater inflow conditions. 


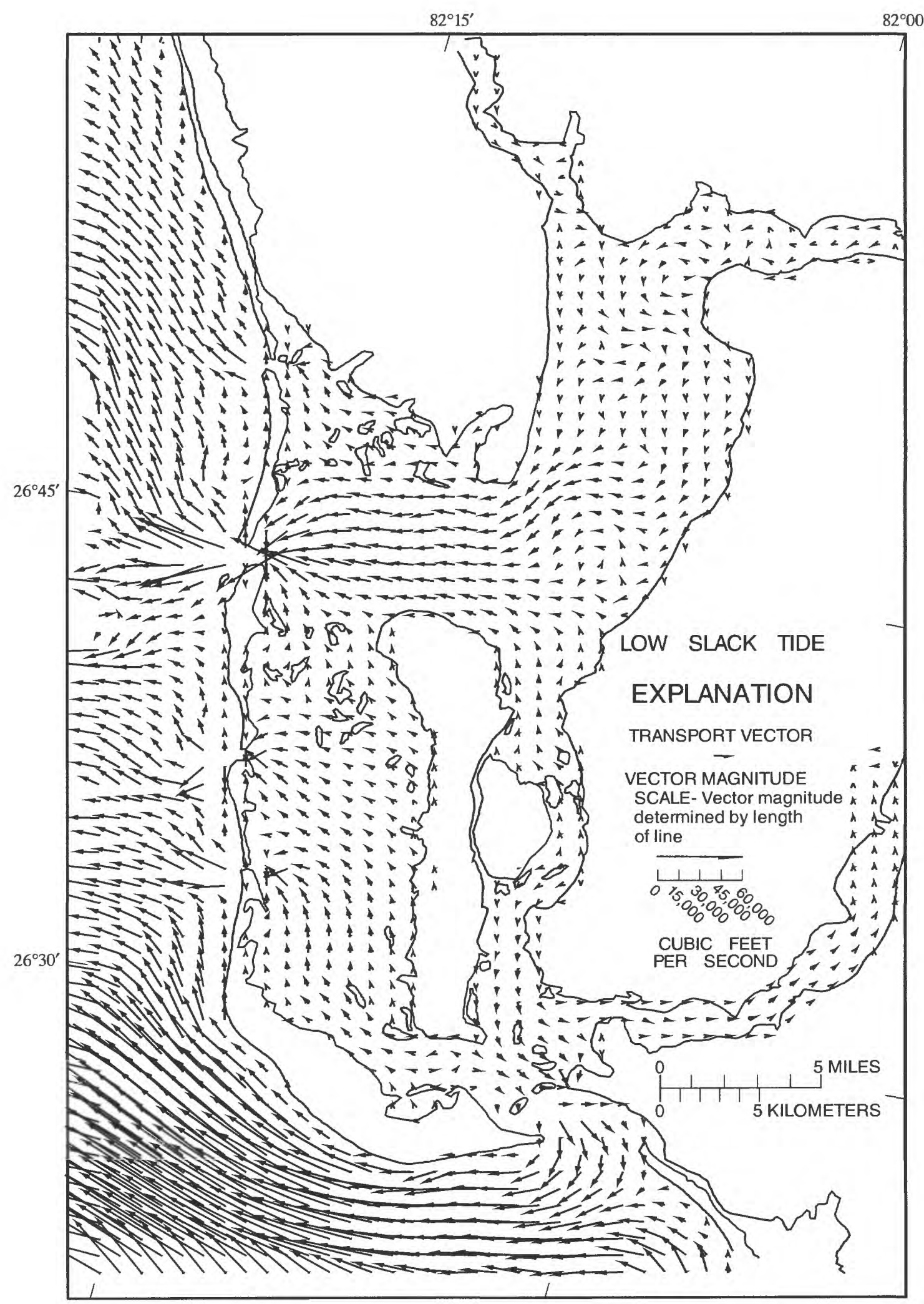

Figure 22. Selected water-transport vectors during low-slack tide under typical freshwater inflow conditions. 


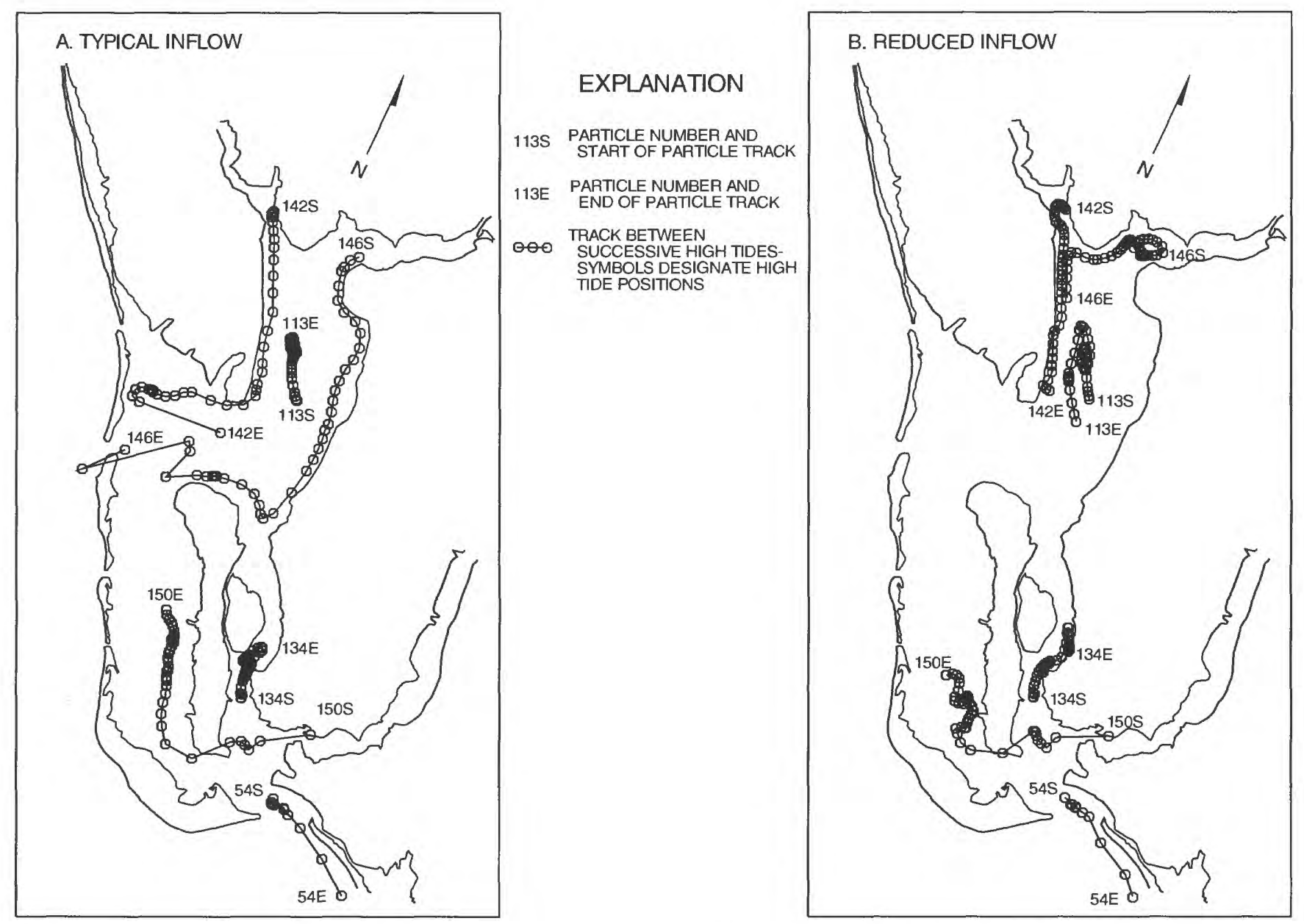

Figure 23. Simulated high-tide particle tracks for (a) typical freshwater inflow and (b) reduced freshwater inflow for synoptically injected particles 54, 113, 134, 142, 146, and 150. 

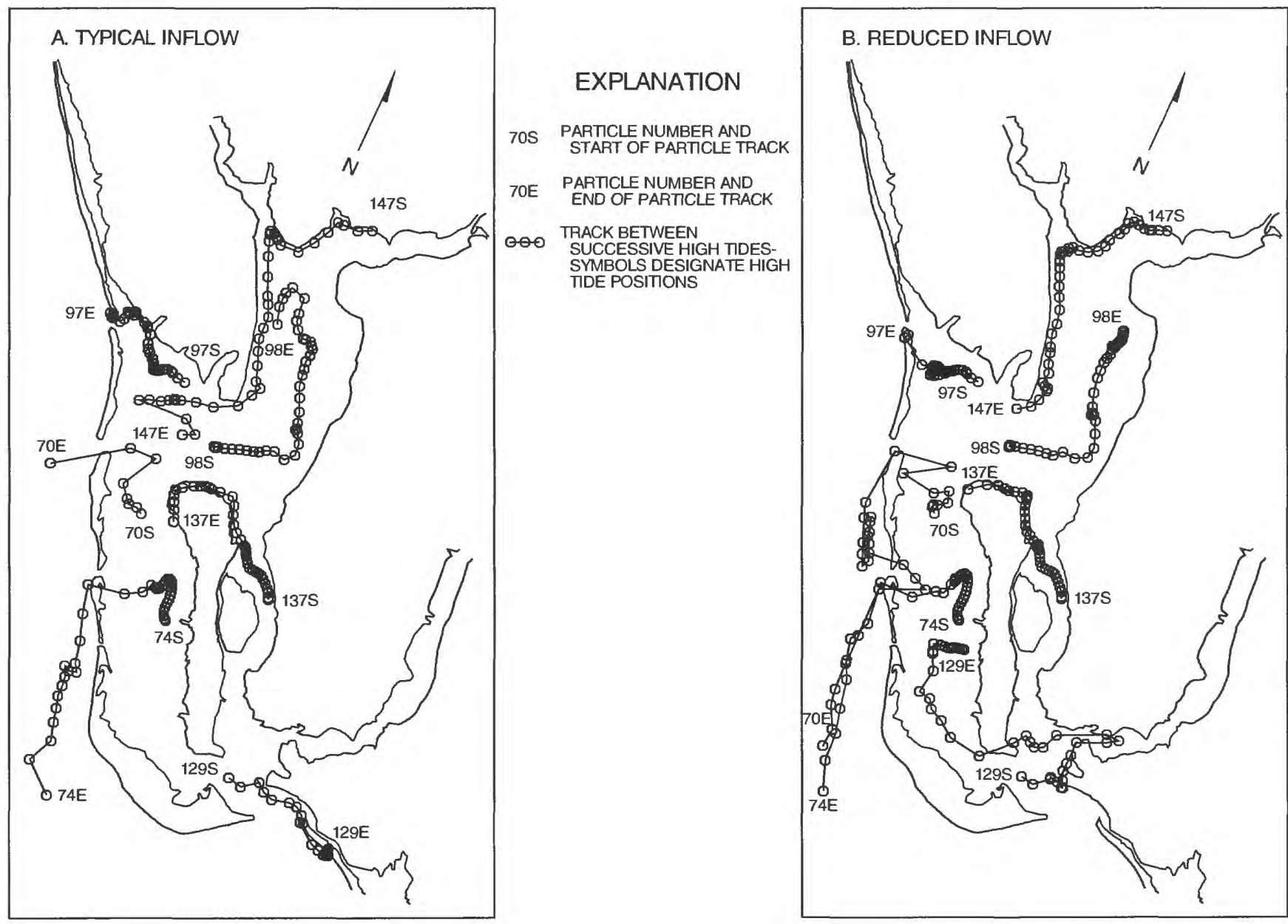

Figure 24. Simulated high-tide particle tracks for (a) typical freshwater inflow and (b) reduced freshwater inflow for synoptically injected particles 70, 74, 97, 98, 129, 137, and 147. 


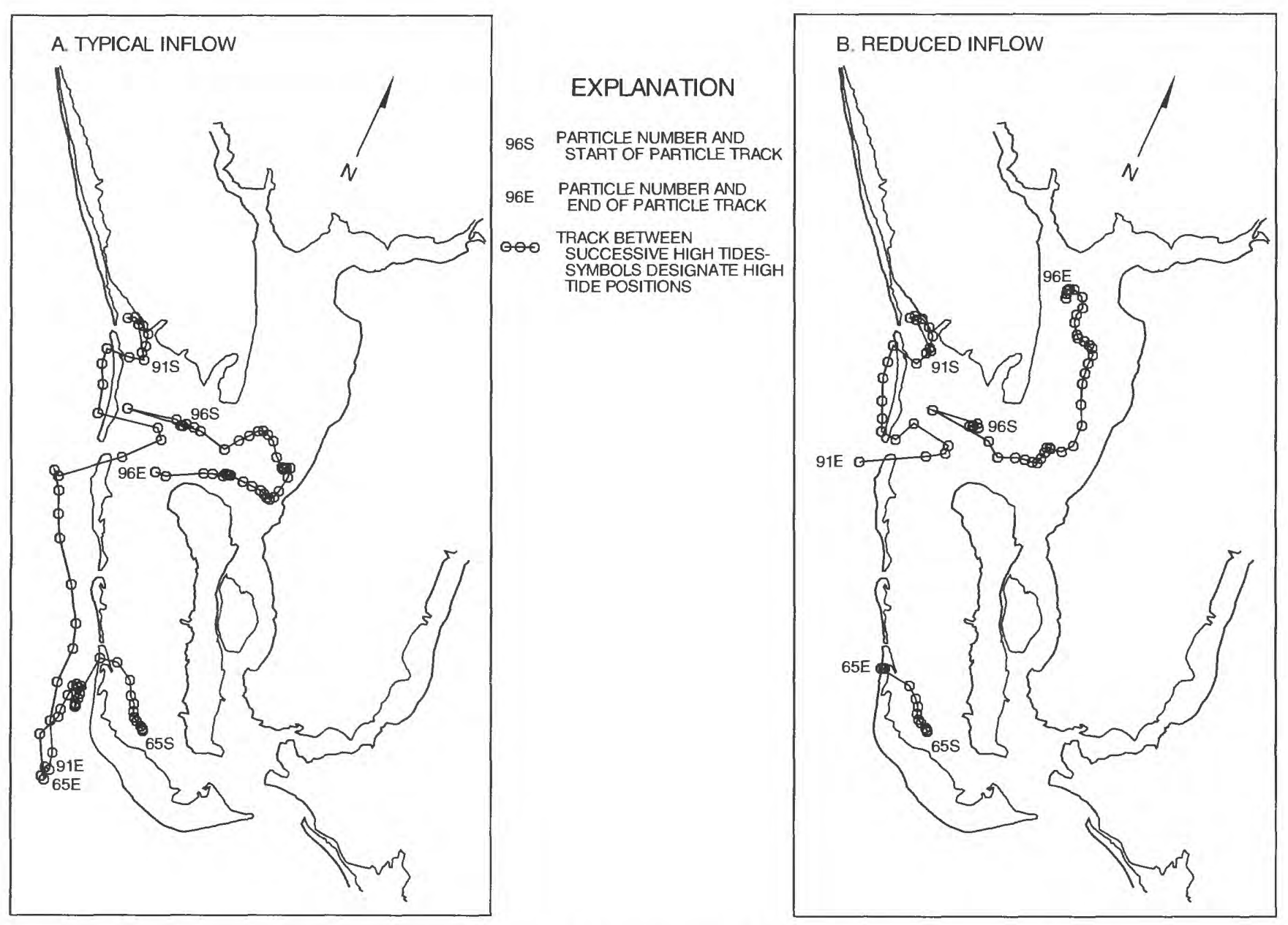

Figure 25. Simulated high-tide particle tracks for (a) typical freshwater inflow and (b) reduced freshwater inflow for synoptically injected particles 65, 91, and 96. 


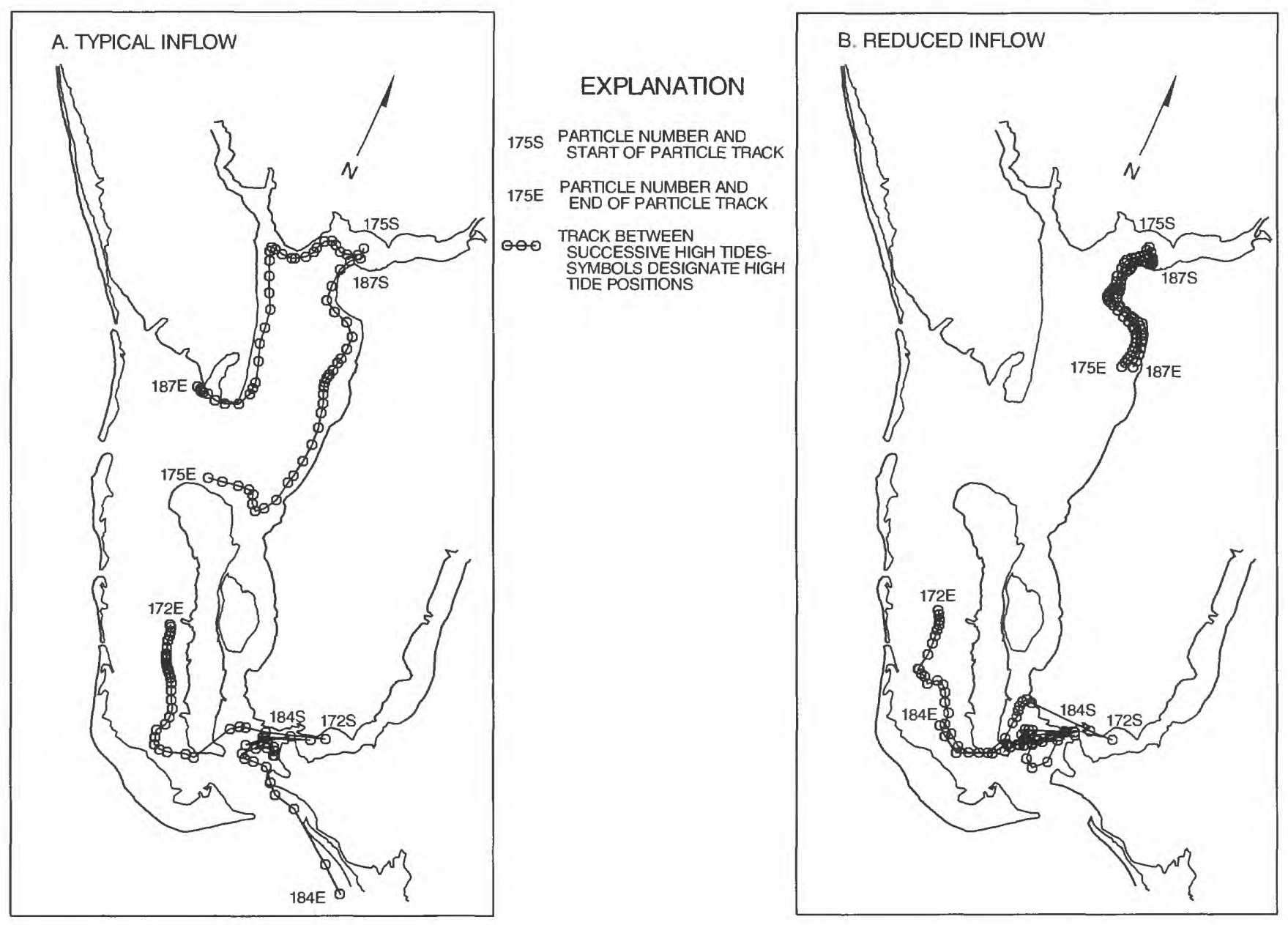

Figure 26. Simulated high-tide particle tracks for (a) typical freshwater inflow and (b) reduced freshwater inflow for sequentially injected particles 172, 175, 184, and 187. 


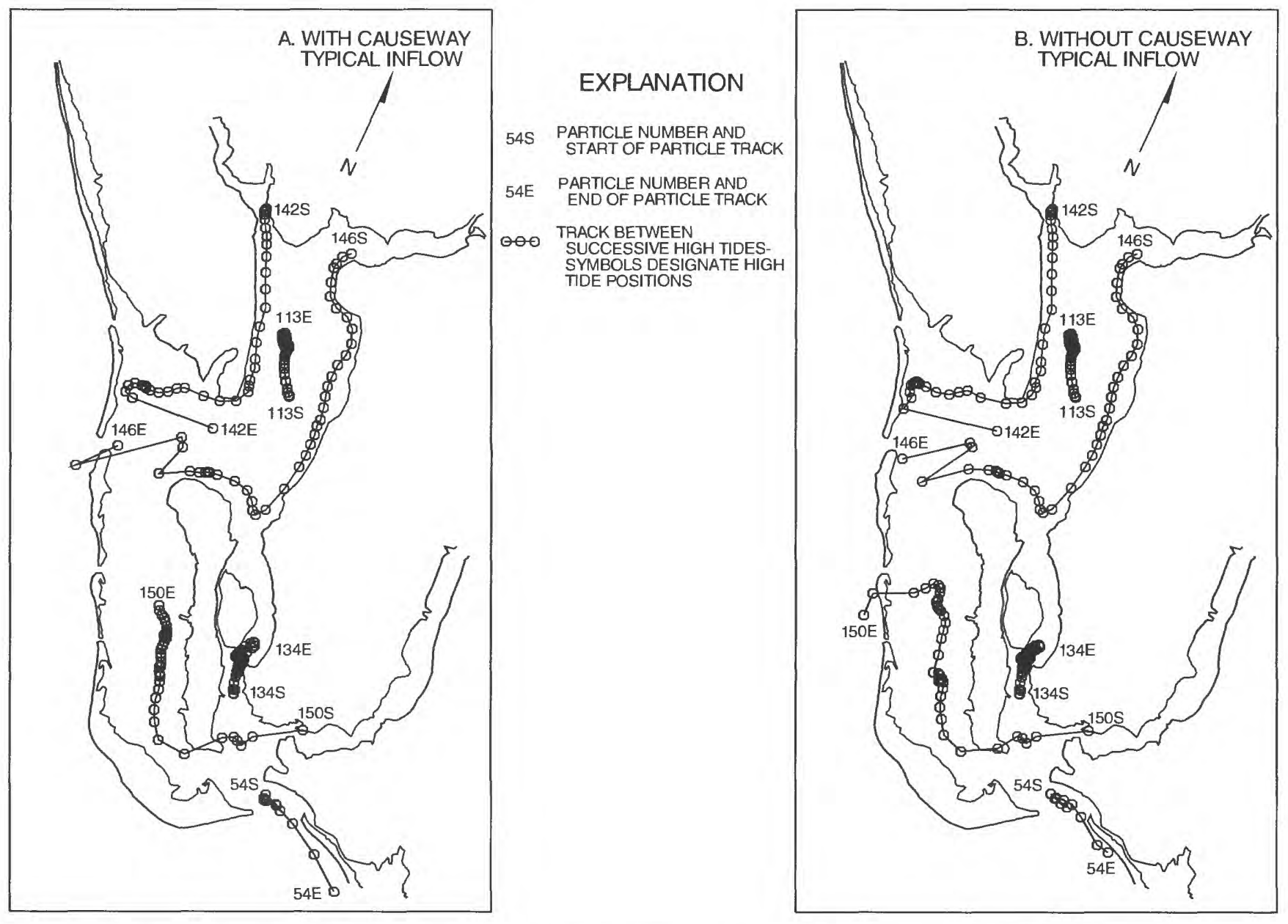

Figure 27. Simulated high-tide particle tracks (a) with the Sanibel Causeway and (b) without the Sanibel Causeway for synoptically injected particles 54, 113, 134, 142, 146, and 150. 


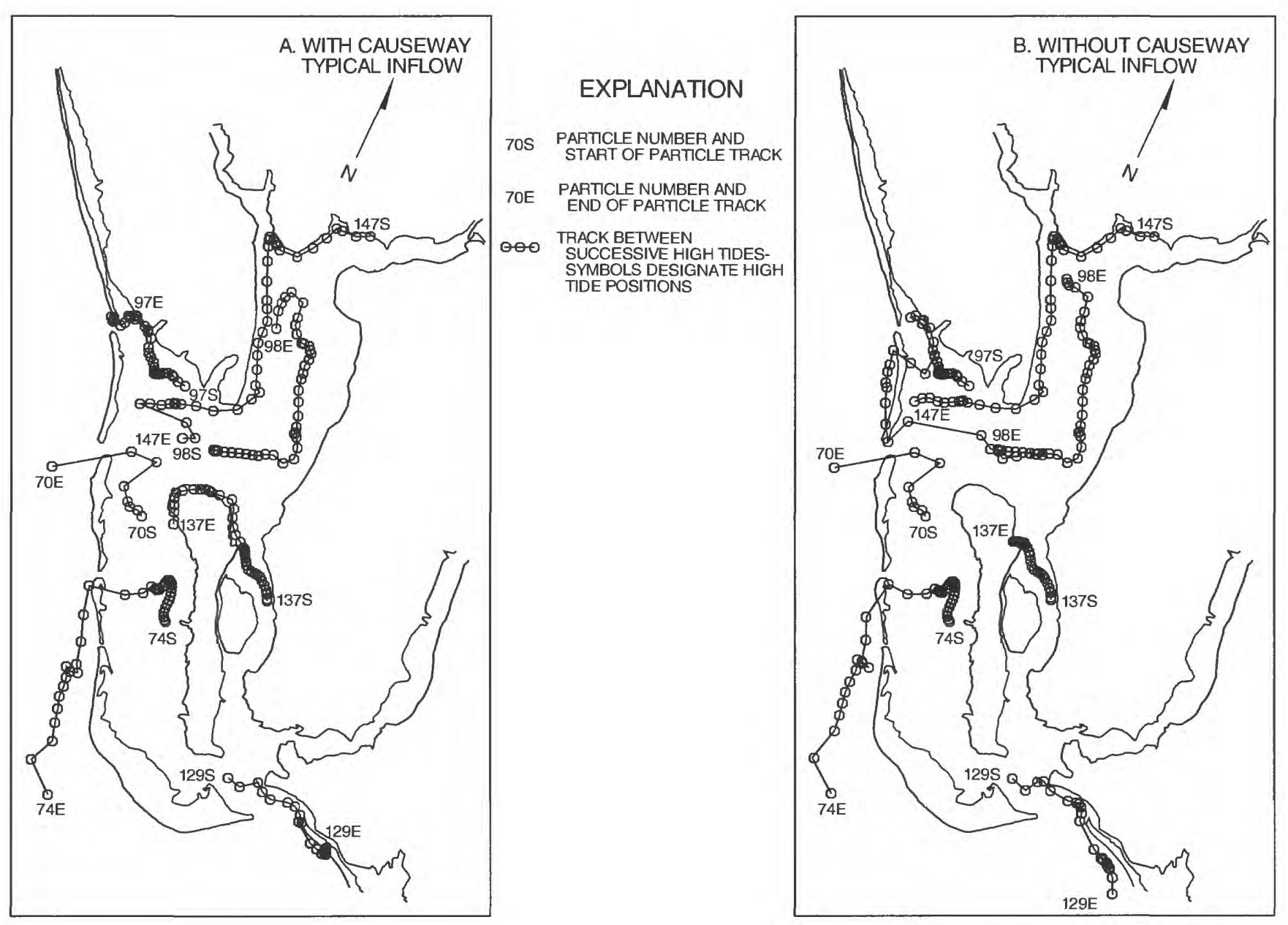

Figure 28. Simulated high-tide particle tracks (a) with the Sanibel Causeway and (b) without the Sanibel Causeway for synoptically injected particles 70, 74, 97, 98, 129, 137, and 147. 


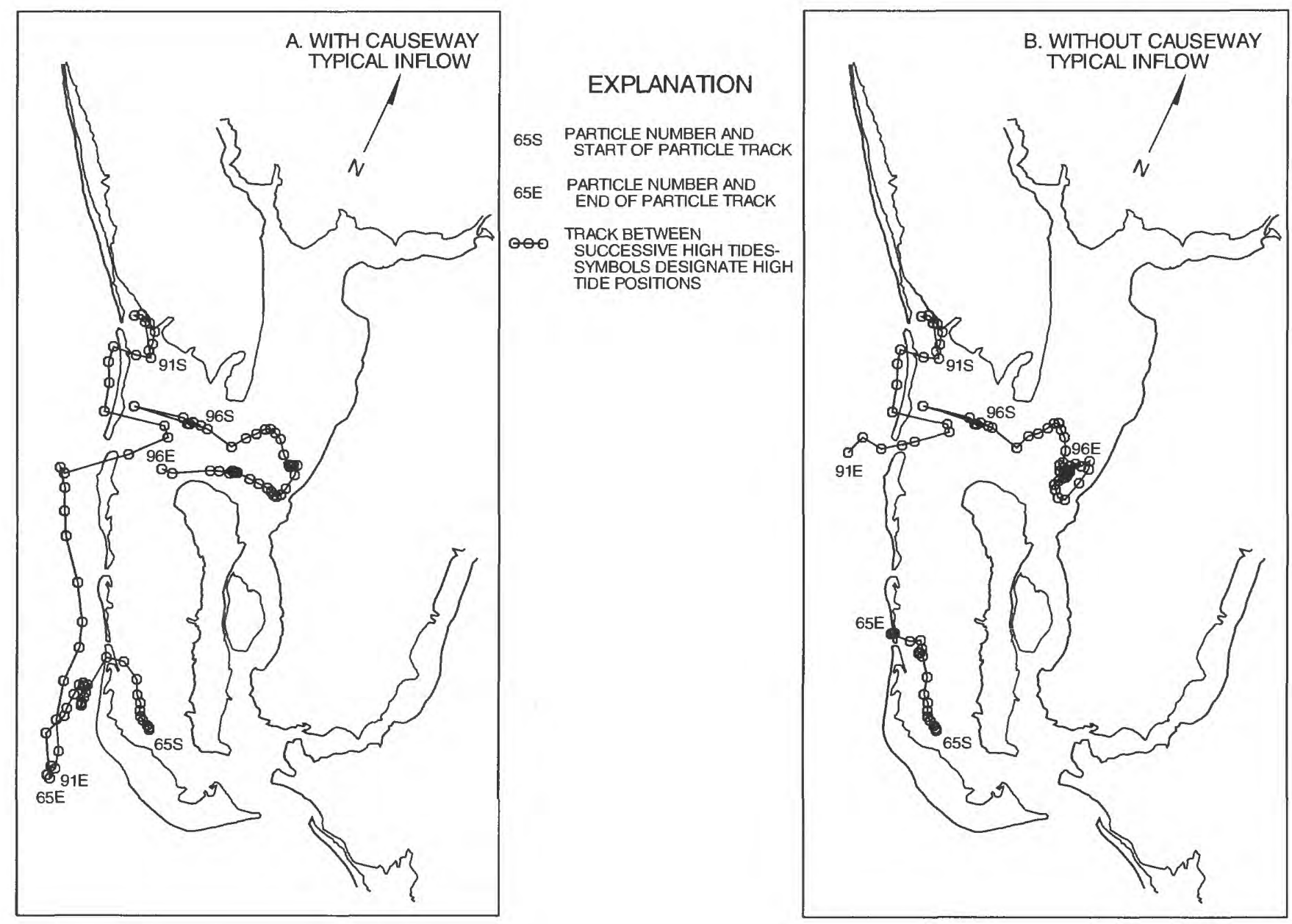

Figure 29. Simulated high-tide particle tracks (a) with the Sanibel Causeway and (b) without the Sanibel Causeway for synoptically injected particles 65, 91, and 96. 


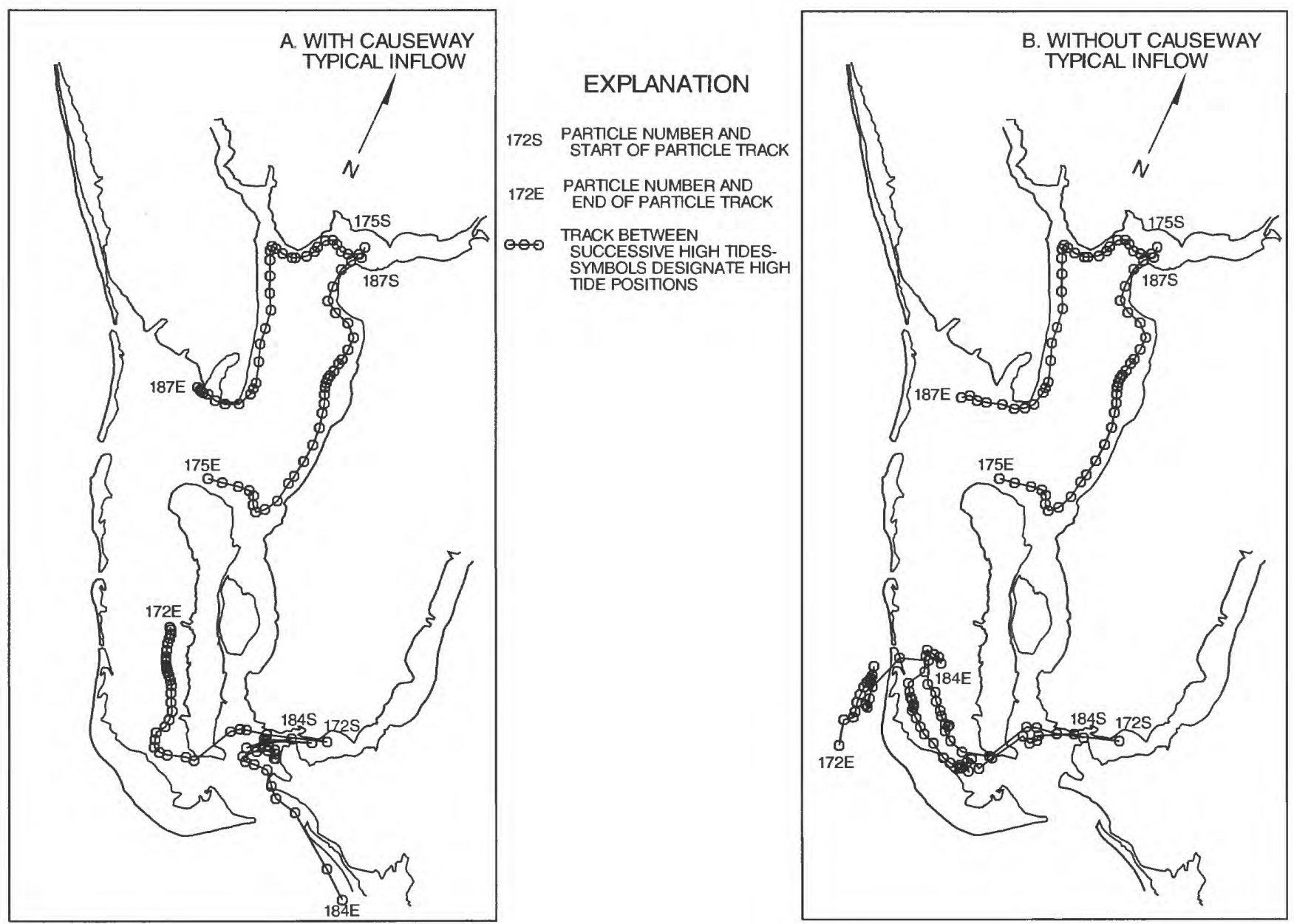

Figure 30. Simulated high-tide particle tracks (a) with the Sanibel Causeway and (b) without the Sanibel Causeway for sequentially injected particles 172, 175, 184, and 187. 


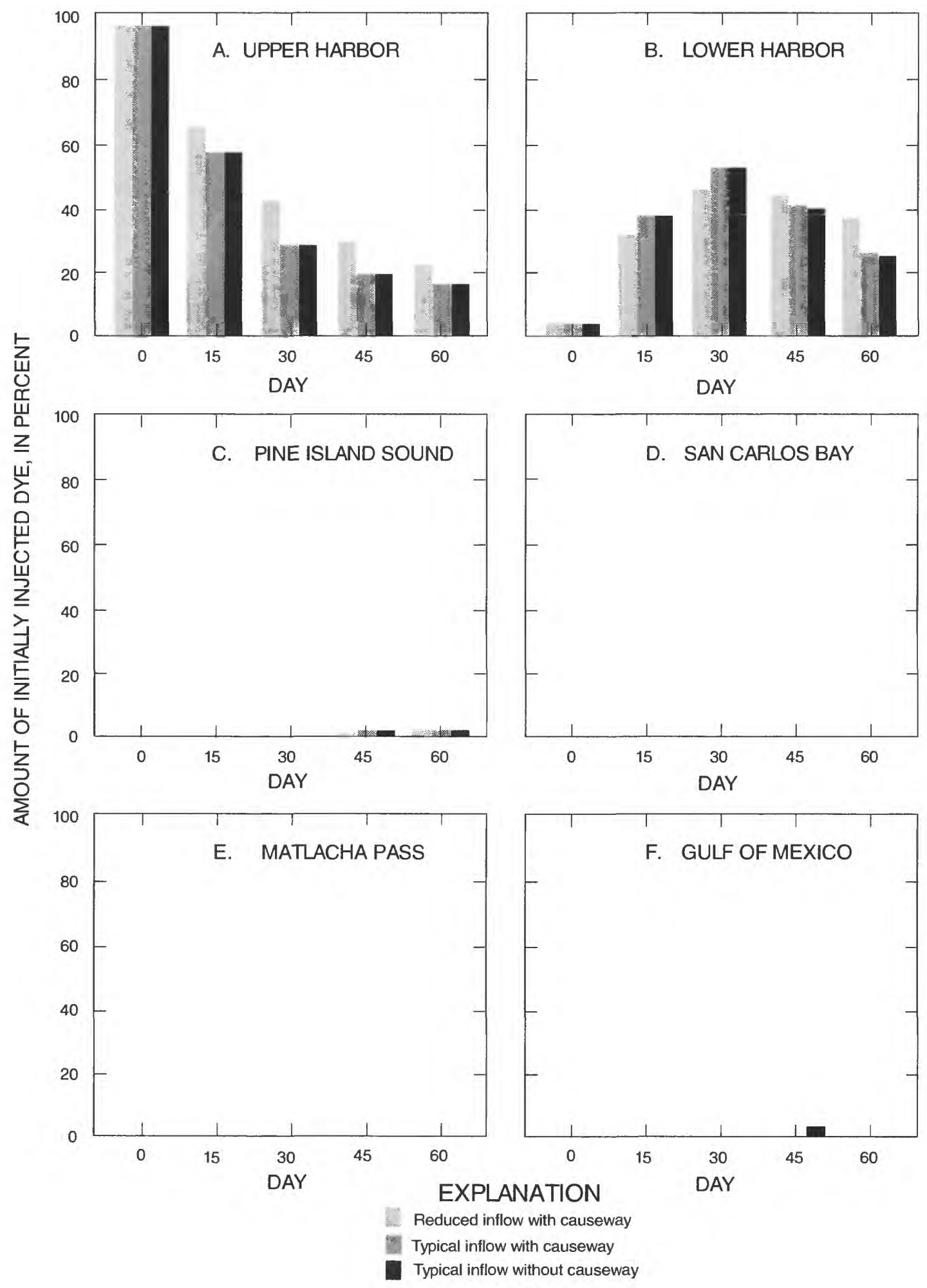

Figure 31. Simulation results from dye injection in upper Charlotte Harbor. 


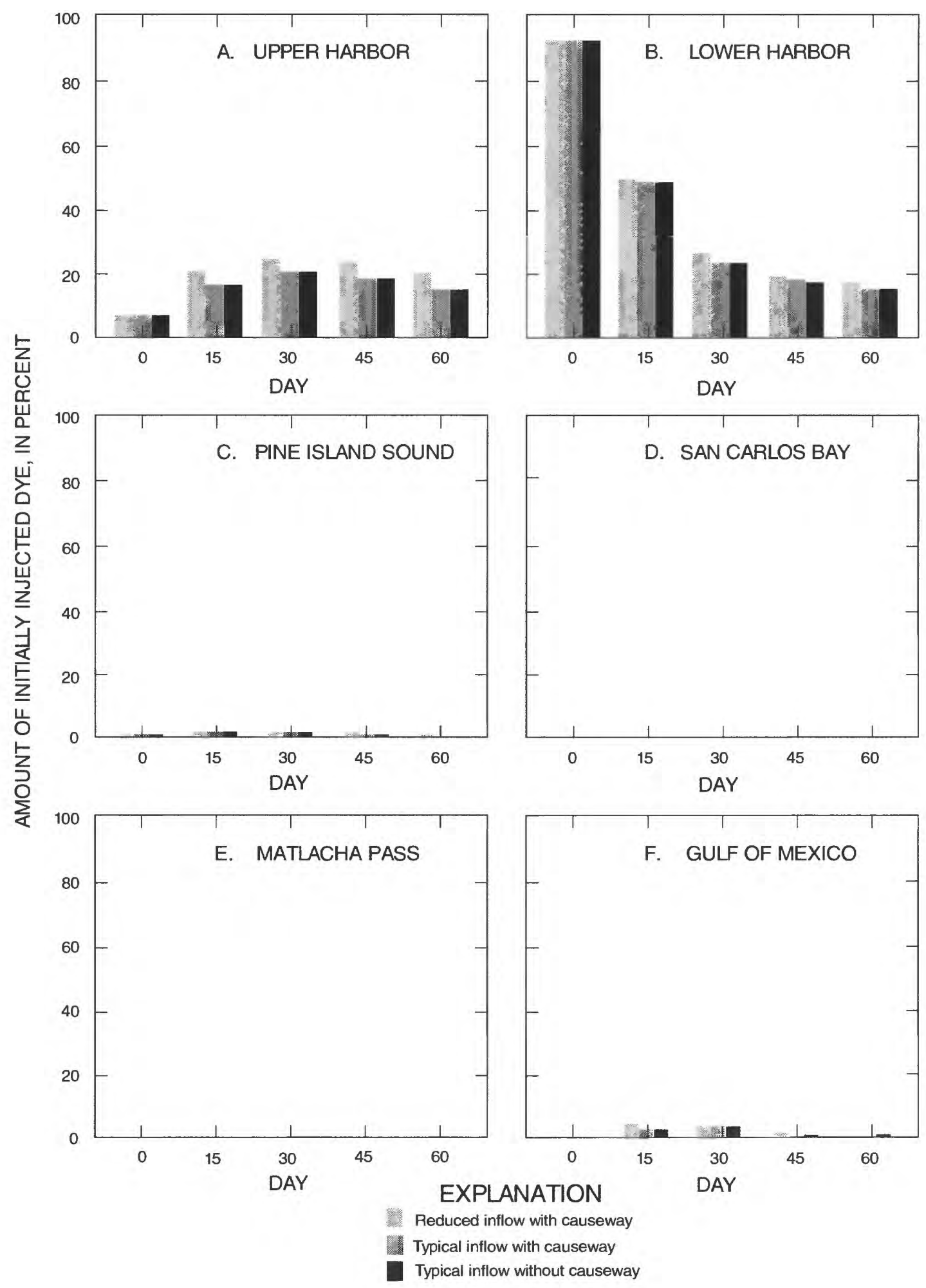

Figure 32. Simulation results from dye injection in lower Charlotte Harbor. 


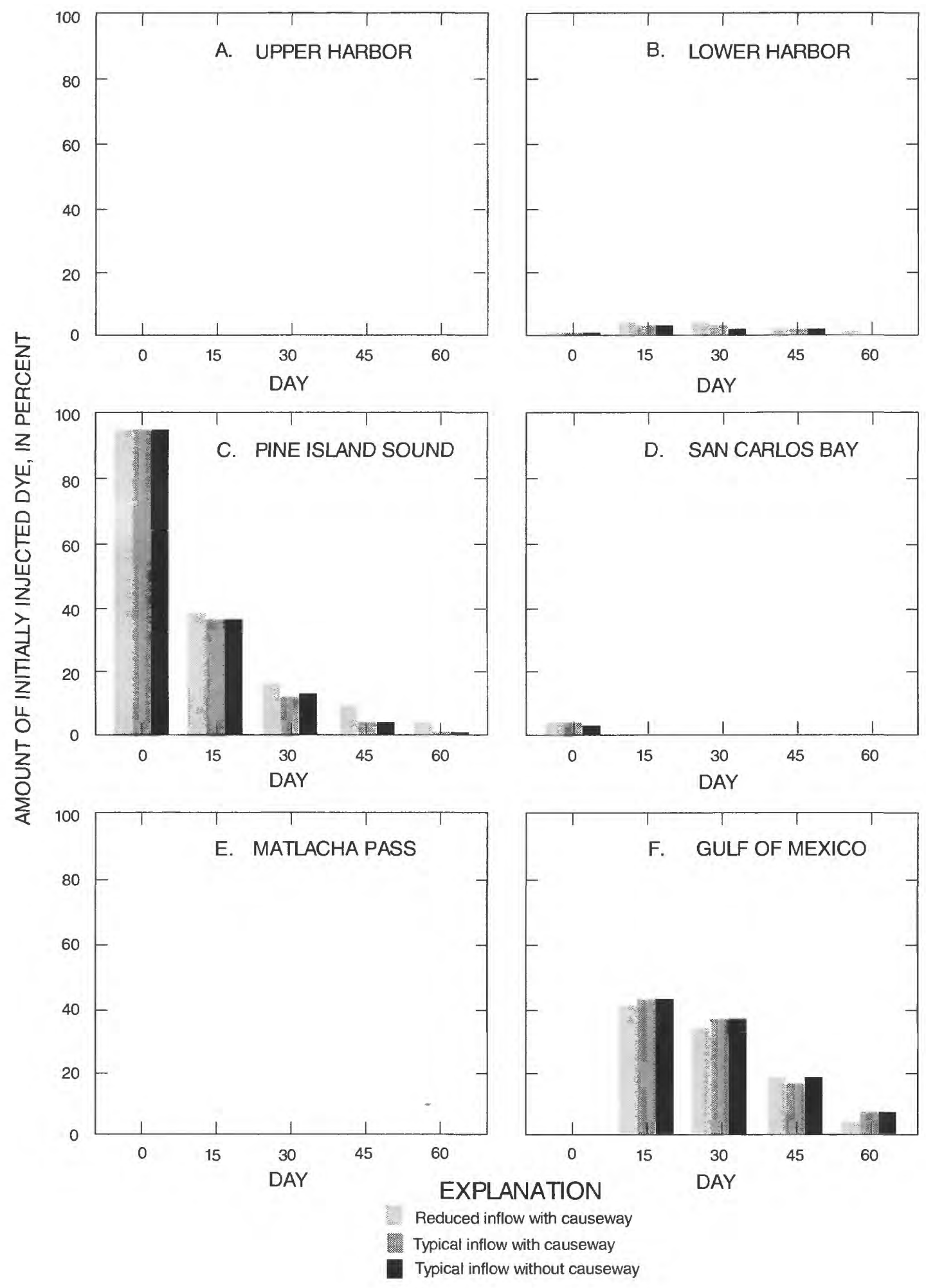

Figure 33. Simulation results from dye injection in Pine Island Sound. 


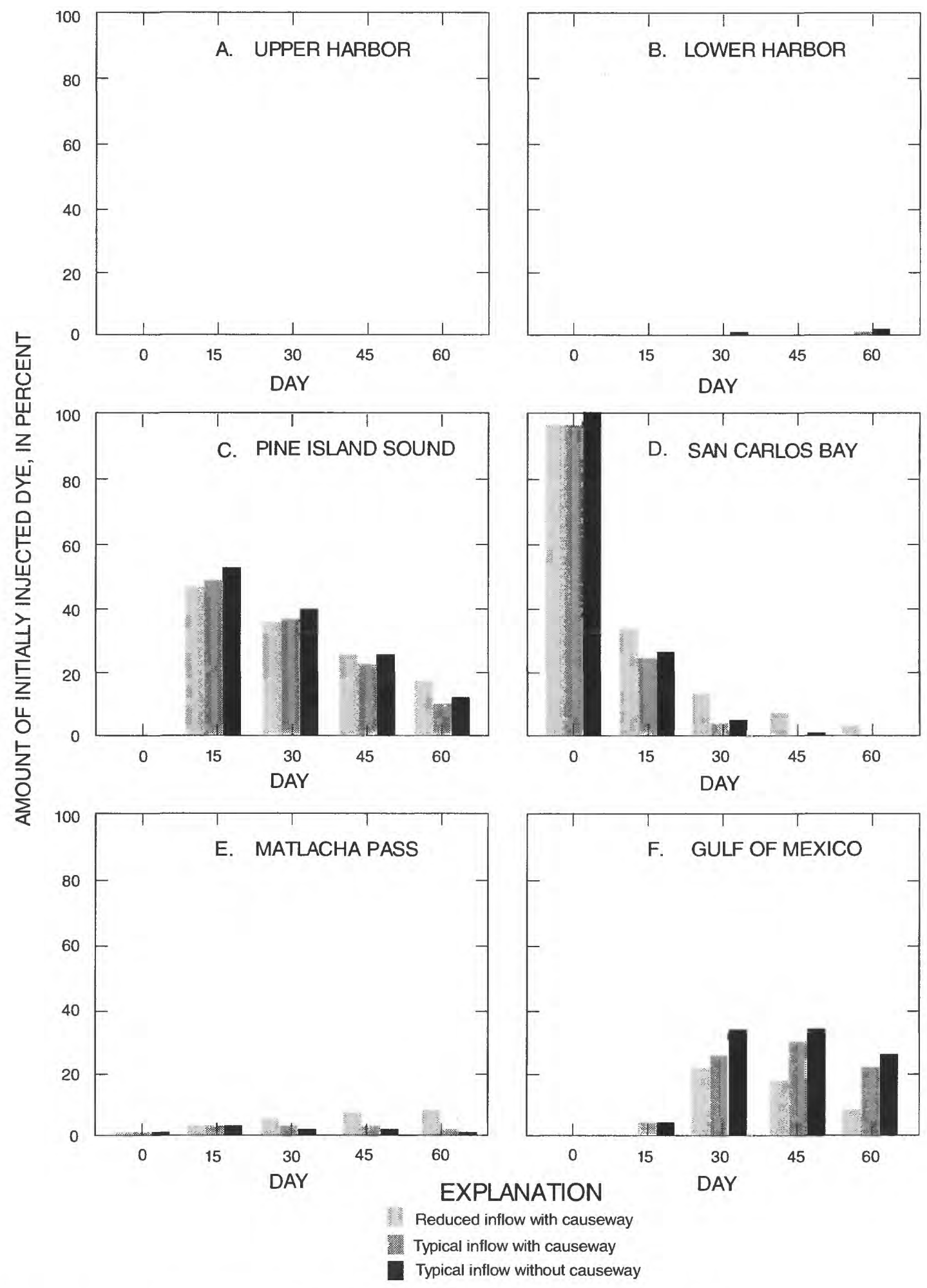

Figure 34. Simulation results from dye injection in San Carlos Bay. 